UNIVERSIDADE DE SÃO PAULO

ORGANIZAÇÕES PATOLÓGICAS E EQUILÍBRIO PSÍQUICO EM PACIENTES DIABÉTICOS TIPO II

MARIA GERALDA VIANA HELENO

SÃO PAULO

2000 


\title{
ORGANIZAÇÕES PATOLÓGICAS E EQUILÍBRIO PSÍQUICO EM PACIENTES DIABÉTICOS TIPO 2
}

\author{
Orientador: Prof. Dr. JOSÉ TOLENTINO ROSA
}

\begin{abstract}
Tese apresentada ao Departamento de Psicologia Clínica do Instituto de Psicologia da Universidade de São Paulo como parte dos requisitos para obtenção do grau de Doutor em Psicologia.
\end{abstract}

Trabalho desenvolvido com o apoio do CNPq

SÃO PAULO

2000 
Ficha Catalográfica preparada pelo Serviço de Biblioteca e Documentação do Instituto de Psicologia da USP

\section{Heleno, M. G. V.}

Organizações patológicas e equilíbrio psíquico em pacientes diabéticos do tipo 2 / Maria Geralda Viana Heleno. - São Paulo, s.n., 2000. 110p.

Tese (doutorado) - Instituto de Psicologia da Universidade de São Paulo. Departamento de Psicologia Clínica.

Orientador: José Tolentino Rosa

1. Mecanismos de defesa 2. Diabetes 3. Escala Diagnóstica Adaptativa Operacionalizada 4. Teste de Relações Objetais de Phillipson 5. Psicanálise 6. Relações de objeto I. Título. 
Ao Reginaldo, meu marido,

com carinho...

A Juliana, Nathalia e Carlos, na esperança

que possam realizar seus sonhos... 
A JOSÉ TOLENTINO ROSA, meu professor e orientador minha gratidão e carinho por ter acreditado em mim e neste trabalho, mesmo antes de eu ter podido imaginá-lo. 
Tudo sob controle, morto....

Encarar o fato de que a nossa própria morte está a caminho e de que as sementes dela já estão em ação gera um longo e amargo período de depressão durante o qual todos os nossos valores passam por uma lenta e dolorosa transformação. O otimismo e o idealismo cedem espaço para uma visão mais sombria e menos esperançosa do mundo como ele é, irredimível, intranqüilo, implacável.

A . Alvarez 
Abdicar do controle, vivo...

O que é novo, vivo é imprevisível e irrecorrível, e requer a cada momento um ato de criação.

Ryad Simon 


\section{AGRADECIMENTOS}

Gostaria de deixar meus agradecimentos e minha mais profunda gratidão a todos meus familiares e amigos que tanto colaboraram para que eu pudesse realizar este trabalho e especialmente:

À minha mãe que com suas doces palavras me acalmou nos momentos mais difíceis.

A Ryad Simon, pessoa muito querida, que me acompanhou e incentivou para experimentar novos caminhos nos quais muito aprendi.

A Kayoko Yamamoto pelas valiosas e generosas contribuições oferecidas neste e em outros trabalhos.

À minha professora e amiga Marília Martins Vizzotto minha gratidão pelas inúmeras “provocações” que suscitaram tantas idéias fundamentais para meu crescimento.

Ao meu querido irmão Marcelo que não mediu esforços para me ajudar na revisão deste trabalho, presença constante na minha vida, minha eterna gratidão pela sua generosidade.

Às minhas irmãs Fauza e Sonia pelo carinho e preocupação constante.

À minha amiga Sueli Rossini, que me levou e trouxe tantas vezes e me acompanhou em tantos momentos, criando possibilidades de eu navegar para ilhas antes desconhecidas. Lembro-me de sua alegria ao me presentear com o livro do John Steiner que eu tanto procurava, sem mesmo saber se ele existia. 
Aos amigos Roberto Salazar, Margarida Mamede e Marisa Soller meu carinho pela colaboração constante e por me ajudar na difícil tarefa de trabalhar em equipe.

A Silvia Di’Pietro e Cássia Souza sempre solícitas facilitando, em tudo o que era possível, minhas atividades no NEAP/UNICSUL.

A Vanda e José Vacari por terem sempre me incentivado para que eu realizasse este trabalho.

Ao Daniel Lerário, Andreia Luciana Lopes Devide, Priscilla Fernandes M. Santos, Sonia Elias e à todos os profissionais e alunos da LIGA pela colaboração.

A Teka, coordenadora do Curso de Psicologia da Universidade Cruzeiro do Sul, por ter compreendido minhas ausências.

Aos pacientes diabéticos que generosamente colaboraram para que este trabalho fosse realizado. 


\section{SUMÁRIO DE CONTEÚDOS}

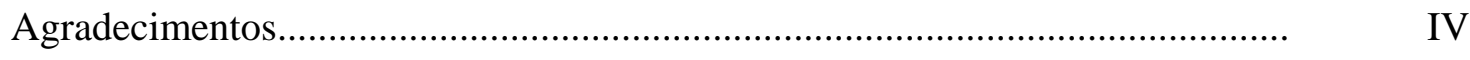

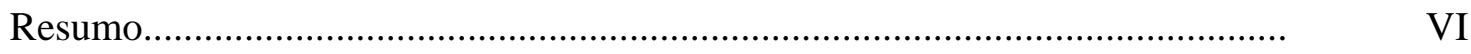

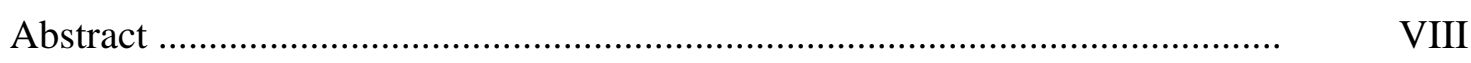

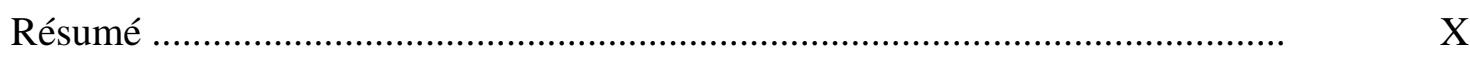

Sumário de Conteúdos ................................................................................... XII

Lista de Anexos ……………………………………………………... XV

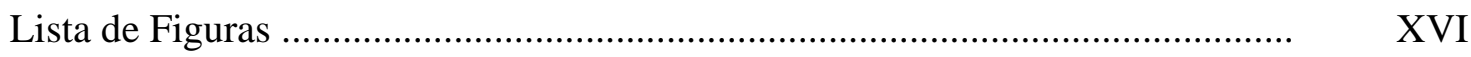

Lista de Quadros ...................................................................................... XVII

Lista de Tabelas ........................................................................................ XVIII

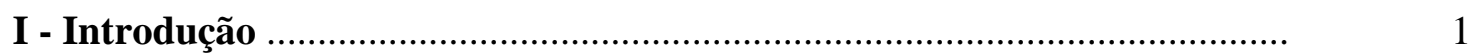

A - Aspectos Epidemiológicos …………………………………………......

B - Conceito do Diabetes ..............................................................................

C - Classificação do Diabetes...................................................................................

D - O Tratamento do Diabetes .......................................................................

E - Psicologia da Saúde e Diabetes Tipo 2 ………………………………......

F - As Organizações Patológicas .................................................................. 13

F.1 - As Posições Viscocárica, Esquizoparanóide e Depressiva.................... 17

G - Instrumentos de Avaliação ........................................................................

G.1 - O Teste das Relações Objetais de Phillipson (TRO) ……………….... 26

G.2 - Escala Diagnóstica Adaptativa Operacionalizada (EDAO) ................ 30

G.3 - Ficha de Avaliação Sócio-Econômica ............................................... 32

G.4 - Controle da Glicemia ....................................................................

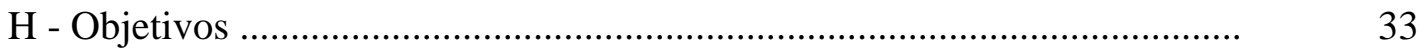

II - Método ............................................................................................

A - Amostra ....................................................................................

B - Recursos Humanos e Materiais .............................................................. 
C - Procedimentos ....................................................................... 36

C.1 - Ficha de Avaliação Sócio-Econômica ............................................... 39

C.2 - Escala Diagnóstica Adaptativa Operacionalizada (EDAO) 39

C.3 - O Teste das Relações Objetais de Phillipson (TRO)

III - Resultados e Discussão

A. Análise comparativa dos resultados apresentados por trinta pacientes diabéticos do tipo 2, divididos em Grupo I, de bom controle, e Grupo II de mau controle

A.1 - Análise comparativa da eficácia adaptativa em pacientes diabéticos tipo 2, divididos em Gr I, de bom controle, e Gr II, de mau controle glicêmico

A.2 - Análise comparativa do equilíbrio interno do ego em pacientes diabéticos tipo 2, divididos em Gr I, de bom controle, e Gr II, de mau controle glicêmico

A.3 - Análise Comparativa de Frequência das Posições Depressiva, Esquizoparanóide e Viscocárica em Pacientes diabéticos do Tipo 2, divididos em Gr I, de Bom Controle, e Gr II, de Mau Controle ...

A.4 - Medindo a presença das Organizações Patológicas através de micro-fatores extraídos da análise da EDAO

A.5 - Medindo a presença das Organizações Patológicas através da análise das defesas no Sistema Tensional Inconsciente Dominante (TRO) ....

B - Análise qualitativa dos resultados apresentados por trinta pacientes diabéticos do tipo 2, divididos em Grupo I, de bom controle, e Grupo II, de mau controle

B.1 - Análise através da Escala Diagnóstica Adaptativa Operacionalizada - EDAO 
XI

C - Análise através do Teste das Relações Objetais de Phillipson - TRO........ 67

C.1 - Análise comparativa na Série A ................................................... 67

C.1.1 - Análise da Lâmina A1(1) .................................................. 68

C.1.2 - Análise da Lâmina A2(2) ................................................ $\quad 70$

C.1.3 - Análise da Lâmina A3(8) .................................................. $\quad 72$

C.1.4 - Análise da Lâmina AG(5) ................................................ $\quad 74$

C.2 - Análise comparativa na Série B .................................................. 77

C.2.1 - Análise da Lâmina B1(6) ...................................................

C.2.2 - Análise da Lâmina B2(9) .................................................... $\quad 80$

C.2.3 - Análise da Lâmina B3(4) .................................................... 83

C.2.4 - Análise da Lâmina BG(10) ................................................ $\quad 85$

C.3 - Análise comparativa na Série C ................................................... 86

C.3.1 - Análise da Lâmina C1(12) .................................................. $\quad 86$

C.3.2 - Análise da Lâmina C2(11) ................................................ 88

C.3.3 - Análise da Lâmina C3(3) .................................................. $\quad 89$

C.3.4 - Análise da Lâmina CG(7) ................................................. 91

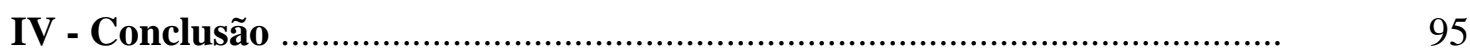

V - Referências Bibliográficas ................................................................. 101 
LISTA DE FIGURAS

Figura 1 - Amostra de Pacientes Diabéticos Com Bom Controle Glicêmico

Figura 2 - Amostra de Pacientes Diabéticos Com Mau Controle Glicêmico .......... $\quad 44$

Figura 3 - Eficácia Adaptativa em Pacientes Diabéticos do Tipo 2 ........................ 47

Figura 4 - Equilíbrio Interno do Ego em Pacientes Diabéticos Tipo 2 ................... 50 
Lista de Tabelas

Tabela 1 Pacientes diabéticos com bom controle glicêmico - Gr I

Tabela 2 Pacientes diabéticos com mau controle glicêmico - Gr II

Tabela 3 Eficácia Adaptativa em pacientes diabéticos com bom controle

glicêmico - Grupo I

Tabela 4 Eficácia Adaptativa em pacientes diabéticos com mau controle

glicêmico - Grupo II

Tabela 5 Equilíbrio adaptativo do ego em pacientes diabéticos com bom controle glicêmico - Gr I

Tabela 6 Equilíbrio Adaptativo do Ego em Pacientes Diabéticos com Mau Controle Glicêmico - Gr II

Tabela 7 As Posições Depressiva, Esquizoparanóide e Viscocárica em 30 pacientes diabéticos do tipo 2, divididos em Grupo I e Grupo II 


\title{
LISTA DE ANEXOS
}

\author{
Anexo I Ficha de Avaliação Sócio Econômica \\ Anexo II Folha de Resumo Diagnóstico para Pesquisa - Escala Diagnóstica \\ Adaptativa Operacionalizada (EDAO) \\ Anexo III Termo de Consentimento \\ Anexo IV Roteiro de Avaliação do Teste das Relações Objetais de Phillipson \\ (TRO)
}


Heleno, Maria Geralda Viana - Organizações Patológicas e Equilíbrio Psíquico em Pacientes Diabéticos do Tipo 2.

São Paulo, 2000 - Tese de Doutorado apresentada ao Instituto de Psicologia da Universidade de São Paulo.

$110 \mathrm{p}$.

\section{Resumo}

Através da prática clínica, notamos em alguns pacientes diabéticos uma resistência paralisadora crônica que impede o tratamento. Eles parecem não se darem conta do que se passa com eles e vivem como se o não tratamento fosse algo bom. Sentem-se protegidos e têm a convicção de que nada irá acontecer-lhes. Eles garantem que não sentem nada, nenhum sinal de complicação aguda ou crônica. Pensamos que esta proteção "perversa” pode ser compreendida a partir do estudo das "organizações patológicas”. Elas oferecem grande resistência a mudanças e a experiências de dependência de objeto.

Os objetivos desta pesquisa foram: (1) avaliar o grau de eficácia adaptativa e os episódios de crise; (2) avaliar a dinâmica emocional e o equilíbrio adaptativo do ego, visando a compreensão do sistema tensional inconsciente principal, que pode identificar, ou não, a presença das organizações patológicas; (3) correlacionar o grau de eficácia adaptativa com a presença ou não das organizações patológicas; (4) correlacionar o grau de equilíbrio adaptativo do ego com a intensidade da ação das organizações patológicas e (5) correlacionar a qualidade do controle glicêmico com a presença ou não das organizações patológicas. Os instrumentos utilizados foram a Escala Diagnóstica Adaptativa Operacionalizada - EDAO e O Teste das Relações Objetais de Phillipson TRO. O controle da glicemia foi determinado através de exames de laboratório.

Foram sujeitos desta pesquisa 30 pacientes diabéticos do tipo 2, amostra representativa e imparcial de uma população de 113 pacientes diabéticos atendidos no primeiro semestre de 1999 na Liga dos estudantes para o atendimento do pacientes diabético - LIGA, do Centro de Diabetes da Universidade Federal de São Paulo UNIFESP. Os sujeitos, de ambos os sexos, tinham idade entre 44 e 62 anos e foram 
divididos em dois grupos. O grupo I era formado por 15 pacientes com bom controle glicêmico e o grupo II, por 15 pacientes com mau controle. Os dois grupos foram controlados por seis meses, durante os quais as recomendações da Sociedade Brasileira de Diabetes - SBD(1999) foram utilizadas para determinar a qualidade do controle glicêmico. A partir deste critério os grupos foram definidos. Os pacientes com glicose plasmática de jejum (GJ) < 126 mg/dl e Glicose Casual (GC) $<200$ mg/dl foram considerados de bom controle e formaram o Grupo I. Acima ou igual a estes valores, Grupo II, de mau controle.

Os resultados mostraram que existe forte correlação entre a eficácia adaptativa e o equilíbrio interno do ego com a qualidade do controle glicêmico. Assim, quanto melhor o nível da adaptação, melhor o controle glicêmico. Da mesma forma, quando as relações de objeto tendem à adaptação ou são positivas, melhor o controle glicêmico.

Quanto à presença das organizações patológicas, a análise através da EDAO e do TRO mostrou que no Grupo I, de bom controle, não foi observada a presença destas organizações. Estes pacientes apresentavam respostas que, cumulativamente, geravam a melhora ou manutenção da eficácia adaptativa. O equilíbrio do mundo interno gerava a possibilidade de adaptação às situações. No Grupo II, de mau controle, pôde-se observar a presença e a intensidade das organizações patológicas. Estes pacientes apresentavam respostas que impediam qualquer tipo de progresso, reduzindo de forma significativa a eficácia adaptativa. No TRO, da mesma forma, observou-se no Grupo II a imobilização ou paralisação frente às situações, fenômeno característico das organizações patológicas 
Heleno, Maria Geralda Viana - Pathological Organizations and Psychological Balance in Patients with Type II Diabetes.

São Paulo, 2000 - Doctorate degree thesis presented to the Instituto de Psicologia da Universidade de São Paulo. 110 pp.

\section{Abstract}

We observed, through clinical practice, that some diabetes patients presented a chronic paralyzing resistance which blocks treatment. They do not seem to realize what is going on with them and live as if the treatment were not a beneficial thing. They feel protected and are sure that nothing will happen to them. They assure that they do not feel anything, any signs of either acute or chronic complications. We think that such "wicked" protection can be understood from the study of the "pathological organizations". These organizations offer great resistance to changes and object-dependant experiences.

The purposes of this study were: (1) to assess the level of adaptive effectiveness and the crisis episodes; (2) assess the emotional dynamics and the adaptive balance of the ego, aiming at understanding the main unconscious stressing system, which might identify the presence or absence of pathological organizations; (3) to correlate the level of adaptive effectiveness with the presence or absence of pathological organizations; (4) to correlate the level of adaptive balance of the ego with the intensity of action of the pathological organizations; and (5) to correlate the quality of the control of glycemia with the presence or absence of pathological organizations. The instruments used were the Adaptive Operational Diagnostic Scale (Escala Diagnóstica Adaptativa Operacionalizada - EDAO) and the Phillipson Object Relations Test (Teste das Relações Objetais de Phillipson - TRO). The control of glycemia was determined by laboratory tests.

Along this study, 30 Type II diabetes patients were observed, which represents a significant and impartial sample from a population of 113 diabetes patients treated during the first half of 1999 at the Students' league for the treatment of diabetes patients (LIGA), from the Diabetes Center of Universidade Federal de São Paulo - UNIFESP. The patients, from both genders, were aged from 44 to 62 and were divided into two groups. Group I had 15 patients with a good control of glycemia 
whereas Group II had 15 patients with a bad one. Both groups were controlled for six months, along which they applied the recommendations from the Brazilian Society for Diabetes (Sociedade Brasileira de Diabetes - SBD - 1999) in order to determine the quality of the control of glycemia. From this criterion the groups were defined. Patients with Plasmatic Fast Glucose (GJ) < 126 mg/dl and Casual Glucose (GC) < 200 mg/dl were considered as having a good control and so they were part of Group I. Figures above or equal to these values were included in Group II, as having a bad control.

The results showed that there is a strong correlation between the adaptive effectiveness and the internal balance of the ego with the quality of the control of glycemia. Therefore, the higher the level of adaptation, the better the control of glycemia. Likewise, whenever the object relations either tend to adaptation or are positive, the better the control of glycemia.

As for the presence of pathological organizations, the analysis through EDAO and TRO showed that in Group I, with a good control, such organizations were not observed. These patients presented responses which, on a cumulative basis, generated either the improvement or maintenance of the adaptive effectiveness. The balance of the inner world generated the possibility of adaptation to situations. In Group II, with a bad control, we observed the presence and intensity of pathological organizations. These patients presented responses that blocked any type of progress, thus significantly the adaptive effectiveness. In TRO, likewise, we observed that in Group II the immobilization or paralysis before situations, which is a typical phenomenon of pathological organizations. 
Heleno, Maria Geralda Viana - Organisations Pathologiques et Équilibre Psychique sur des Patients Diabétiques du Type 2. São Paulo - 2000 These de doctorat présentée à I’Institut de Psychologie de I’Université de São Paulo.110 pages.

\section{Résumé}

À travers la pratique technique nous remarquons chez quelques patients diabétiques, une résistance paralytique cronique qui empéche leur traitement. IIs ne se redent pas compte de ce qui se passe avec eux et vivent comme si le traitement était quelque chose de bien. Iis se sentent protégés et sont convaincus que rien de mal ne leur surviendra. Iis assurent quills ne ressentent rien, aucun signe de complication aigue ou cronique. Nous pensons que cette protection "perverse” peut etre saisie à partir de I'étude des "organisations pathologiques". Celles-ci présentent une grand résistance aux changements et aux expériences de dépendance de I'objet.

Les objectifs de cette recherche ont été les suivants: (1) Évaluer le degré d'éfficacité d'adaptation et les épisodes de crise; (2) Évaluer la dynamique émotionnelle et I'équilibre d'adaptation du "soi-même", ayant comme but la compréhension du système de tension inconscient principal, qui peut ou ne peut pas identifier la présence d'organisations pathologiques; (3) Établir une correlation entre le degré d'efficacité d'adaptation et la présence ou l'absence d'organisations pathologiques; (4)Établir une correlation entre le degré de l'équilibre d'adaptation du "soi-même" et I'intensité de I'action des organisations pathologiques. Les instruments utilisés ont été I'Echelle Diagnostique d'Adaptation Opérationnelle - EDAO et le Teste des Relations des Objets Phillipson - TRO.

Trente patients diabétiques du type 2 ont été soumis à cette recherce. Essai représentatif et impartiel sur une population de 113 patients diabétiques reçus pedant le premier semestre 1999 à la Ligue des Étudiants pour I’Accueil des Patients Diabétiques LIGA, du Centre de Diabètes de I’Université Fédérale de São Paulo - UNIFESP. Les personnes, des deux sexes, avaient entre 44 et 62 ans et ont été divisés em deux groupes. Le groupe I était formé par 15 patients avec um bom contrôle de glucose et le groupe II, composé par 15 patients, avec um mauvais contrôle de glucose. Ces deux groupes ont été contrôles pendant six mois, période à laquelle les recommandations de la Société Brésilienne de Diabètes - SBD (1999) ont été utilisées pour déterminer la qualité du contrôle glycémique. À partir de ce critère les groupes ont été définis. Les patients avec glucose plasmatique 
de jeúne $(\mathrm{GJ})<126 \mathrm{mg} / \mathrm{dI}$ ont été considérés. Bien contrôlés et ont formé le groupe I. Au-dessus ou à la même hauteur de ces valeurs, le groupe II a subi um mauvais contrôle.

Les résultats démontrent qu'il existe une forte correlation entre I'efficacité d'adaptation et I’équilibre interne du “soi-même”avec la qualité du contrôle glycémique. Autant le niveau d'adaptation est bom, autant le contrôle glycémique sera bom aussi. II em est de même pour les relations de I'objete qui ont une tendance à I'adaptation ou sont positifs: nous obtiendrons um meilleur contrôle glycémique.

L'analyse de I'EDAO et du TRO, démontre que dans le groupe I, de bom contrôle, la présence des organisations pathologiques n’a pas été observée. Ces patients présentaient des réponses qui, peu à peu, géraient um maintien ou une amélioration de I’efficacité d'adaptation. L'équilibre du monde interne gérait la possibilité d'adaptation aux situations. Dans le groupe II, de mauvais contrôle, nous observons la présence et I’intensité des organisations pathologiques. Ces patients présentaient des réponses qui empêchaient n'importe quel type de progrès et réduisait de façon significative I'efficacité d'adaptation. II em est de même, lorsqu'il s’agit du TRO: nous avons remarqué dans le groupe II I'immoblisation ou la paralisation face aux situations, phénomêne caractéristique des organisations pathologiques. 


\section{ORGANIZAÇÕES PATOLÓGICAS E EQUILÍBRIO PSÍQUICO EM PACIENTES DIABÉTICOS TIPO 2}

\section{I - INTRODUÇÃO}

A importância dos estudos sobre diabetes se deve ao fato de que ela é um problema de saúde universal e, no Brasil, está entre os quatro mais importantes problemas em termos de pessoas afetadas. Os elevados custos para o controle e tratamento das complicações aliados aos casos de mortalidade e incapacidade decorrentes da doença justificam que o problema seja tratado como público.

\section{A - ASPECTOS EPIDEMIOLÓGICOS}

O Estudo Multicêntrico da Prevalência do Diabetes Mellitus no Brasil (Franco et al, 1990) mostrou que 7,6\% da população adulta urbana do Brasil é diabética. Desses, $46,5 \%$ desconheciam sua condição e 22,3\%, embora conscientes do problema, não faziam qualquer tipo de tratamento. Estes dados são de grande importância, porque mostram a negligência em relação ao controle da doença, primordial para evitar complicações agudas e crônicas.

Estudo recente de prevalência de diabetes mellitus (Torquato et al., 1998) mostra que na região de Ribeirão Preto - SP o índice chega a 13,2\%. Os autores acreditam que a incidência do Diabetes Mellitus vem aumentando nos últimos anos em função de mudanças no estilo e aumento da média de vida da população, inclusive do diabético. Este último é um fator positivo pois, para os autores do estudo, é o resultado de melhores condições de atenção à saúde. Outro dado novo neste trabalho se refere ao conhecimento da doença. Dos indivíduos pesquisados, $76 \%$ já conheciam sua condição. O conhecimento, entretanto, não garante um bom controle, o que explica nesta região os altos níveis de mortalidade por doença cardiovascular, uma das complicações crônicas do diabetes. 
O comitê formado pela Organização Mundial de Saúde e Associação Americana de Diabetes recomendou a diminuição no valor de corte para o diagnóstico de Diabetes. A alteração do valor foi de $140 \mathrm{mg} / \mathrm{dl}$ para $126 \mathrm{mg} / \mathrm{dl}$. Nasri et al. (1998) estudaram o impacto do novo valor da glicemia de jejum no diagnóstico de diabetes mellitus em indivíduos idosos. A nova classificação elevou o índice de prevalência para 19,8\% contra 16,3\% da classificação anterior.

\section{B - CONCEITO DO DIABETES}

O diabetes é uma doença conhecida há aproximadamente 3.500 anos e pode ser definido como um estado causado por insulina disponível insuficiente. Apesar de esta definição ser verdadeira, diabetes não se resume a isso. Podemos dizer que é uma síndrome complexa, caracterizada por: hiperglicemia; complicações microvasculares específicas que levam ao desenvolvimento de retinopatia e nefropatia; doença macrovascular (aterosclerose acelerada); outras complicações como neuropatia, gestação complicada, tendência a infecções e cetoacidose.

\section{C - CLASSIFICAÇÃO DO DIABETES}

O diabetes pode ser classificado, segundo o “National Diabetes Data Group”, em Tipo 1, Tipo 2, Gestacional, Intolerância à glicose e Secundário. O diabetes mellitus tipo 1 ou insulino dependente é caracterizado, clinicamente, por início abrupto dos sintomas, insulinopenia, dependência de insulina exógena e propensão à cetose. Geralmente, este tipo de patologia ocorre em jovens. Entretanto, a doença pode ser reconhecida em qualquer idade.

No diabetes mellitus tipo 2, ou não insulino dependente, o paciente apresenta sintomatologia leve e produção de insulina em pequena quantidade. Em geral, pode ser controlado por restrições dietéticas e medicamentos orais, que podem ajudar na estimulação da liberação de insulina. Os sintomas são: fome, sede, micções frequentes, perda de peso e cansaço. Nas mulheres ocorrem, muitas vezes, irritação severa e prurido 
vaginal. O diabetes tipo 2, geralmente, aparece após os trinta anos. Este tipo de diabetes é muitas vezes negligenciado pelo próprio paciente, em função deste início mais "suave" em relação aos sintomas. Existe a referência a uma doença silenciosa. Este é um dos mais sérios problemas, pois as alterações de açúcar no sangue, mesmo não tão elevadas, (glicemia entre $150 \mathrm{mg} / \mathrm{dl}$ e $250 \mathrm{mg} / \mathrm{dl}$ ), podem trazer complicações irreversíveis a médio prazo. Decorre deste fenômeno a necessidade do trabalho preventivo junto ao paciente diabético do tipo 2.

O diabetes gestacional é caracterizado por intolerância à glicose, que surge durante a gestação em mulheres não diabéticas. Essa alteração metabólica no período pós-parto voltará à normalização na maioria dos casos. Estas pacientes, quando não controlam adequadamente a disfunção, apresentam elevado risco de complicações perinatais.

O diabetes caracterizado por intolerância à glicose ocorre com alguns indivíduos que apresentam glicemia de jejum normal, e os níveis glicêmicos durante o teste oral de tolerância à glicose apresentam valores intermediários entre os normais e os diabéticos. Os indivíduos com essa característica possuem um risco maior de se tornarem diabéticos e de apresentarem doenças cardiovasculares.

Outro tipo de diabetes é o secundário, relacionado a certas condições e síndromes, como alterações hormonais, doenças do pâncreas, anormalidades nos receptores de insulina, síndromes genéticas e uso de remédios.

\section{D - O TRATAMENTO DO DIABETES}

Os procedimentos empregados para o diagnóstico de Diabetes Mellitus, conforme recomendação da Sociedade Brasileira de Diabetes (SBD), são a medida da glicose no soro ou plasma após jejum de 8 a 12 horas e o teste de tolerância à glicose (TTG). Este último é feito após a administração de 75 gramas de glicose anidra (ou dose equivalente) 
por via oral, com medidas de glicose no soro ou plasma nos tempos 0 e 120 minutos após a ingestão.

Em função de sua praticidade, a medida da glicose plasmática em jejum (GJ) é o procedimento básico para fazer o diagnóstico de DM. Será considerado diabético o indivíduo que apresentar a GJ $\geq 126 \mathrm{mg} / \mathrm{dl}$. Se não houver a presença de sintomatologia característica da hiperglicemia, o diagnóstico deverá sempre ser confirmado pela repetição de teste em outro dia.

Após o diagnóstico, o foco recai sobre o tratamento e a meta a ser atingida é evitar as complicações agudas e crônicas do diabetes. O estudo mais importante sobre o tratamento do diabetes é o United Kingdom Prospective Diabetes Study - UKPDS (1998). O objetivo deste estudo foi analisar se o controle rigoroso da hiperglicemia e da hipertensão arterial eram capazes de reduzir as complicações e consequentemente a mortalidade em pacientes diabéticos do tipo 2. O trabalho concluiu que o aumento da mortalidade cardiovascular dos pacientes diabéticos está relacionado ao estado diabético em si e à agregação de vários fatores de risco cardiovasculares, como obesidade e hipertensão arterial (HA) entre outros. A frequência de HA em pacientes diabéticos é duas vezes maior do que na população em geral.

É fundamental a manutenção do bom controle glicêmico e dos níveis normais da pressão arterial, mas isto não é garantia absoluta do não aparecimento das complicações. A recomendação da SBD é de que o tratamento inclua educação, modificação do estilo de vida, suspensão do fumo, aumento da atividade física e reorganização dos hábitos alimentares. "Quanto ao controle glicêmico, deve-se procurar atingir valores os mais próximos do normal ( $\leq 110 \mathrm{mg} / \mathrm{dl}$ ). Como muitas vezes não é possível, aceita-se, nestes casos, valores de glicose plasmática em jejum até $126 \mathrm{mg} / \mathrm{dl}$, acima deste valore é sempre necessário realizar intervenção para melhorar o controle metabólico.”(SBD, 1999, p.9)

A complexidade do diabetes, a multiplicidade de fatores envolvidos e a falta de conhecimentos são empecilhos para o tratamento. Não podemos negligenciar o progresso 
feito nos últimos 10 anos em relação ao aprimoramento do diagnóstico e melhora do atendimento ao paciente diabético, mas a situação ainda é grave e investimentos devem ser feitos no que se refere à motivação do diabético para um tratamento eficiente.

Muitos autores, como Krall (1983), Tatterson (1985), Kaplan et al (1987), Davidovich (1989), entre outros, mostraram que o tratamento eficiente, que é a manutenção de um bom controle glicêmico, está centrado em dois fatores: dieta e exercícios físicos. O terceiro, quando necessário, é a medicação. Eles concluem que os pacientes capazes de aderirem ao tratamento melhoram de forma significativa a qualidade de vida.

A dificuldade no tratamento ocorre em função da complexidade da doença, da necessidade de profissionais competentes e, principalmente, da motivação do paciente para aderir ao tratamento. Por melhor que sejam os profissionais, percebemos a responsabilidade que envolve o diabético e a carga psicológica a ele imposta.

“Assim, o grande desafio para os profissionais de saúde foi encontrar técnicas adequadas que ajudassem os pacientes diabéticos a aderirem ao tratamento e terem uma vida saudável.”(Heleno, 1992, p.26)

Vários autores como Docherty (1988), Lúcio et al. (1990), Lima et al. (1990) chamaram à atenção para a importância do trabalho educativo e já acrescentaram que para alguns casos havia a necessidade de implementar outros tipos de estratégia.

Booty (1992) estudando as diferenças entre pacientes diabéticos com bom, regular e pobre controle glicêmico, concluiu que o conhecimento sobre a doença é um método insuficiente, quando usado sozinho, para beneficiar o controle sobre o diabetes.

Cummings (1992) discute a relação entre um sistema de suporte ao paciente diabético e a melhora da aderência ao tratamento. Ele afirma que várias 
pesquisas têm demonstrado que os pacientes que recebem tratamento psicológico podem fazer melhor uso dos serviços médicos.

\section{E - PSICOLOGIA DA SAÚDE E DIABETES TIPO 2}

As discussões sobre o papel do psicólogo na saúde mental principalmente na higiene mental, têm ocorrido há algum tempo. Da utilização do modelo médico geralmente restrito à prática da medicina privada e individualista, até a busca de um modelo próprio e mais eficiente no contexto social, o psicólogo permaneceu de certa forma paralisado e sem muitas possibilidades de mudanças.

Apesar do vasto campo de trabalho preventivo e grande referencial teórico e prático da psicologia clínica, a dificuldade de mudança para uma atitude de psicohigienista, termo utilizado por Simon (1989), parece residir em dois fatores. O primeiro é que não se pode simplesmente transportar os conhecimentos e as técnicas utilizadas pelo psicólogo clínico, para um trabalho institucional e de caráter preventivo. O segundo reside na questão da atitude do psicólogo frente a seu papel profissional. Sobre isso, Bleger assinala a importância de se fazer "a administração dos conhecimentos, atividades técnicas e recursos psicológicos que já foram adquiridos, para encarar os aspectos psicológicos da saúde e da doença como fenômenos sociais e coletivos. Temos que adquirir uma dimensão social da profissão do psicólogo e, com isto, consciência do lugar que ela ocupa dentro da saúde pública e da sociedade”( Bleger, 1984, p.21).

Outro aspecto utilizado por Bleger (1984) para justificar a utilização do modelo médico pelo psicólogo era a situação social e econômica da época, embora ele tenha previsto que ela se transformaria rapidamente. De fato, a mudança ocorreu, e por várias razões. As mais importantes foram o aumento populacional, o empobrecimento social, maior incidência de doenças e o aumento do número de psicólogos.

Aproximadamente 30 anos depois, Simon (1989) confirma a previsão de Bleger (1962). Referindo-se à necessidade da criação de programas preventivos, que poderiam atender a demanda social, evitando o agravamento das situações de saúde pública, e 
contemplar também a situação de dificuldade do psicólogo, ele diz: "Tais programas poderiam proporcionar a colocação utilíssima para grande número de psicólogos ou outros psico-higienista relegados à ociosidade ou aceitando ocupação alheia à profissão para subsistirem (isso em si já seria um programa de prevenção do desajustamento do próprio psicólogo)” (Simon, 1989, p. 66).

Apesar da incongruência entre a pequena oferta de emprego para o psicólogo e as amplas possibilidades de atuação, cabe ao psicólogo, de certa forma, encontrar seu lugar. Sobre isso, Bleger faz a seguinte afirmação: "São muito variados os campos de atuação do psicólogo clínico; mas se este se acha interessado predominantemente nos problemas psicológicos da saúde, tem que se situar corretamente no, até agora, pouco definido campo da higiene mental e, à medida em que o vá fazendo, o campo irá se configurando mais clara e nitidamente” (Bleger, 1984, p.20).

Para Bleger “A função social do psicólogo clínico não deve ser basicamente a terapia e sim a saúde pública e, dentro dela, a higiene mental. O psicólogo deve intervir intensamente em todos os aspectos e problemas que concernem à psico-higiene e não esperar que a pessoa adoeça para poder intervir. Estas são verdades que não se põem teoricamente em dúvida, mas que não se fazem ainda práticas na dimensão necessária” (Bleger, 1984, p.20).

Este problema da inserção do psicólogo nas instituições é complexo e sua solução não depende apenas do psicólogo, mas também de mudanças políticas nas esferas estadual e federal, como a anunciada no Informativo do Conselho Federal de Psicologia. A nota diz: “Os psicólogos conquistam mais um grande espaço no campo profissional. Tornou-se obrigatória a presença de profissionais especialistas em Psicologia Clínica no Serviço de Suporte, como um dos critérios para cadastramento de Centros de Atendimento em Oncologia, junto ao SUS (Sistema Único de Saúde). A determinação consta na Portaria nº 3.535 do Ministério da Saúde, publicada no Diário Oficial da União de 14/10/98." 
Apesar das medidas como a anunciada acima, muito há que se fazer para a mudança do quadro geral das dificuldades do psicólogo e do papel deste dentro das equipes de saúde. Assim como na Oncologia, o trabalho do psicólogo é fundamental também em outras equipes de saúde, nos mais diversos setores das instituições com as mais diversas patologias, bem como na prevenção das mesmas.

Simon (1989) sugere que em países menos desenvolvidos e sem recursos, poderia haver a implantação de programas de prevenção que no âmbito da saúde pública, atendessem os pacientes em situações de crise. O objetivo colocado pelo autor seria de: “Propiciar benefício coletivo que poderia advir da aplicação de uma estratégia de saúde mental aplicada no momento em que o sofrimento humano é mais agudo, cujos danos são muito mais onerosos em termos de padecimento emocional e mesmo material” (Simon, 1989, p.66). Ele ainda relaciona uma série de instituições onde estes programas poderiam ser realizados. Entre eles, podemos destacar as Delegacias de Polícia, Juizado de Menores, Hospitais Gerais, Orfanatos e Escolas, etc.

Este tipo de programa poderia também ser implantado em ambulatórios de especialidades, como é o caso do diabetes mellitus que, como qualquer doença crônica, pode produzir profundas alterações psicológicas, impedindo a aceitação da doença (Mutti,1990). Neste aspecto, um programa preventivo é de fundamental importância, na medida em que pode levar o paciente diabético a um bom controle glicêmico e, com isto, evitar complicações agudas e crônicas. Atualmente, não se discute o fato de que um bom controle glicêmico pode prevenir, retardar ou atenuar as complicações decorrentes dos altos níveis de açúcar no sangue. Mas, fundamentalmente, pode-se melhorar a qualidade de vida destes pacientes e isto é um grande ganho.

Assim como outras disciplinas, a psicologia pode trazer importantes contribuições à equipe de saúde como ao paciente diabético. O papel das emoções deve ser reconhecido no curso do diabetes e a mudança mais importante deve ocorrer nas equipes de saúde. Davies (1989) conclui que o psicólogo é um agente de importantes informações que levarão o paciente diabético a lidar melhor com sua doença. Com isso, ele poderá evitar 
ou diminuir sofrimentos e os elevados custos para controle das complicações decorrentes do mau controle glicêmico.

Muitos autores, como Krall (1983), Haynal (1983), Clayer \& Harris (1985), Ebigo (1985), Jensen (1985), Dunn (1986), Davies (1989), Lima (1991), Heleno (1992), Kreger (1992), Vazquez et al. (1994) e Cleaver \& Pallourios (1994), têm demonstrado a importância dos aspectos psicológicos tanto no desencadeamento como no curso do diabetes mellitus.

Ross (1987), revisando a literatura, aponta para um aspecto muito importante: o fato de um número significativo de casos terem o diagnóstico após situações de perda. Um grande número de pacientes abre o quadro após situações de grande emoção, como perda de pai, mãe, doença grave de pessoas queridas, perda de emprego, entre outras. Existem, segundo este autor, vários trabalhos que acentuam a relação do stress com o aumento da glicemia.

O stress como agente hiperglicemiante tem sido objeto de algumas pesquisas. Guimarães (1987) mostra que nos períodos difíceis, como início de novas atividades, observa-se o aumento da glicemia em pacientes diabéticos. Samo (1991) investigou os efeitos do stress psicológico nos níveis de glicemia em pacientes diabéticos do tipo 2. Ele concluiu que sujeitos com diabetes não insulino-dependente mostraram um relativo aumento nos níveis de glicose no sangue durante o stress, quando comparados aos níveis glicêmicos sem stress. A hiperglicemia como resposta ao stress também foi observada por Ma et al. (1988) e Goodrich ( 1994).

Recente estudo de Aikens \& Mayes (1997) teve como objetivo avaliar a associação entre o stress diário, considerando tanto frequência como intensidade de discussões, e a glicemia em pacientes diabéticos do tipo 2. Os autores concluíram que o stress proveniente do trabalho, família e amigos pode ser uma fonte particularmente relevante para o controle da glicemia. Sendo assim, o stress é uma variável a ser controlada na evolução da doença. 
Ainda em relação às pesquisas em diabetes mellitus, cabe lembrar que, de forma geral, a atenção recai sobre o paciente diabético tipo 1. Conforme lembra Goodrich (1994), o foco nos pacientes diabéticos do tipo 2 é especialmente importante, pois a maioria dos estudos chama a atenção para a criança diabética e seus pais. Assim, existe certa escassez de trabalhos envolvendo os pacientes diabéticos mais idosos.

A análise mais detalhada destes pacientes mostra que, a partir do diagnóstico, o diabético encontra-se em uma situação irreversível de perda, parcial ou total, de uma função orgânica de grande importância. A situação de perda ocasiona, geralmente, uma crise em função da ação de fatores negativos. A doença ou a perda da saúde constituemse fatores negativos. Para Simon (1989), a perda súbita de um órgão ou função biológica importante, por doença ou acidente, pode ser um fator negativo para a manutenção da eficácia adaptativa.

Após o desencadeamento do diabetes, podemos observar que a vida do paciente transforma-se. Ele sofre a ação de micro-fatores negativos resultantes das limitações que a doença e o tratamento impõem, que incluem dieta, medicação, exercícios físicos, exames laboratoriais mensais e domiciliares “diários”. O diabetes mellitus, apesar de não incapacitar o doente, é uma doença crônica que prejudica sua adaptação. O paciente necessita conviver com a perda do controle glicêmico e suas consequências.

Nesta nova situação, o paciente diabético precisa mudar seus hábitos e sua rotina. Ele sofre ainda a ameaça constante de novas perdas, decorrentes das complicações crônicas, como retinopatia, neuropatia, macroangiopatia, entre outras. Considerando a situação de crise que envolve o diagnóstico e o curso do diabetes, parece fundamental compreendermos a maneira pela qual o paciente resolve esta situação. Utilizamos neste trabalho o conceito de crise proposto por Simon (1989). Ele considera o essencial na geração da crise o fato de o sujeito viver uma situação nova e transformadora, que implica na redução ou aumento significativo do espaço no universo pessoal. “ A generalização mais ampla nos leva a propor que a crise se deve a aumento ou redução 
significativa do espaço no universo pessoal. Quando dizemos "significativa”, neste contexto, salientamos que se trata de uma incógnita, que por sua vez é função da pessoa real que experimenta essas variações. Chamamos de "universo pessoal” para efeito desta exposição, ao conjunto formado pela pessoa (psicossomático), mais a totalidade de objetos externos (aqui compreendidas outras pessoas, bens materiais ou espirituais e situações sócio-culturais).”(Simon, 1989, p.60)

Anderson (1991) assinala que um paciente, para aceitar a situação imposta pelo fato de estar diabético, precisa possuir capacidade de integrar em seu self uma concepção de "ser diabético”. Para ele, esta se opõe à situação na qual o paciente integra a concepção de "ser doente". Esta última sugere, segundo o autor, uma idéia de perda irreversível e principalmente incapacitante.

Heleno (1992) mostra que, após a situação de crise, alguns pacientes aceitam o fato de estarem diabéticos e seguem o tratamento. Isto ocorre quando suas emoções não são de natureza extrema e poderosa e, consequentemente, são capazes de utilizar as defesas, principalmente a identificação projetiva, de modo flexível e reversível; quando são capazes de suportar a angústia do desconhecido; quando contam com objetos bons e completos firmemente estabelecidos em seu mundo interno e quando são capazes de elaborar o luto. Mas outro grupo, composto por um número relevante de pessoas, não é capaz de ter uma atitude saudável em relação ao diabetes.

Este fenômeno parece estar relacionado à maneira como o paciente elabora o luto. Este refere-se à perda do objeto amado ou de parte valiosa do self. No caso do paciente diabético, podemos dizer que o fato de ele perder o corpo sadio equivale ao luto. O modo como ele enfrenta esta nova situação, se é capaz ou não de suportar a vivência dolorosa da doença e suas consequências e elaborar o luto, pode determinar a aderência ou não ao tratamento. 
O paciente diabético enfrenta um tipo especial de luto em função das sucessivas perdas, reais ou fantasiosas. Assim, nos parece que o estudo do luto nestes pacientes poderia ser de grande importância no entendimento do adoecer diabético.

Em “O luto e os estados maníacos depressivos”, Klein (1940) mostra que no trabalho de luto ocorre a reativação de defesas primitivas como a onipotência, a negação e a idealização, intimamente ligadas à ambivalência e à posição esquizoparanóide. Essas defesas permitem ao ego mais primitivo livrar-se da dependência escravizadora dos objetos amados e mortos. As defesas maníacas, portanto, estão a serviço do ego para permitir que a perda do objeto amado e a culpa sejam suportadas. No luto normal, a morte da pessoa amada real pode trazer o ódio e o sentimento de triunfo sobre o morto, aumentando a culpa. Para Klein, o trabalho ocorre não apenas em relação aos objetos externos como propõe Freud (1917), mas também em relação aos internos. Para ela, todo o mundo interno da pessoa desmorona. Provém desta situação a dificuldade do trabalho de luto, que implica na superação das regressões paranóides e dos mecanismos maníacos.

No luto anormal, a excessiva e interminável ligação com o morto ou a negação da perda não permitem a superação da ansiedade depressiva. A incapacidade de experimentar tristeza pela perda leva à paralisação das emoções e à pobreza afetiva. A negação da perda pode ser compreendida , segundo Simon (1998), através do ataque que o paciente faz à percepção da realidade. Ele afirma: "sugiro que a intolerância à perda do objeto amado seja um tipo específico de ataque perceptivo: ataque à percepção do tempo e concomitantemente ataque à percepção do espaço. O sujeito quer acreditar que nada aconteceu; e que as coisas continuam no mesmo lugar. (Simon,1998, p. 57 )

\section{F - AS ORGANIZAÇÕES PATOLÓGICAS}

Através da observação clínica notamos em alguns pacientes diabéticos uma resistência paralisadora crônica que impede o tratamento. Nestes casos, o paciente parece experimentar um tipo de terror descrito por Meltzer (1967). Para ele “o terror é uma ansiedade paranóide cuja qualidade essencial, a paralisia, não deixa nenhum caminho 
para a ação. Do objeto de terror - que na fantasia inconsciente são objetos mortos - não se pode nem mesmo fugir com sucesso” ( Meltzer, 1991, p.241).

Para estes pacientes o tratamento é sentido como algo muito ruim. O paciente nega a doença e a necessidade do tratamento, a insulina é rejeitada porque "vicia” e “engorda”. O paciente não suporta a dependência do tratamento, incluindo tanto os profissionais de saúde como a própria medicação. Alguns autores mostram a ação de partes onipotentes e destrutivas do self que podem, de forma velada, impedir qualquer relação libidinal positiva Rosenfeld (1971), Rey (1979), O’Shaughnessy (1979), Simon (1984), Sohn (1985), Godoy (1994) e Steiner (1997).

Rosenfeld (1971) descreve um tipo de paciente narcísico que, ao se defrontar com a realidade de ser dependente do analista, atua como um bebê que acredita ser criador de si mesmo e portanto capaz de se cuidar sozinho. A intensidade destes sentimentos varia de acordo com o paciente e depende de como ocorreram os processos de desfusão e fusão das pulsões de vida e de morte. A partir, principalmente, da teoria de fusão e desfusão - proposta por Freud, mais a teoria de Melanie Klein - sobre cisão dos objetos e do ego, Rosenfeld esclarece aspectos destrutivos do narcisismo. Ele considera a fusão dos impulsos de vida e de morte sobre dois aspectos. O primeiro é um tipo de fusão que ele chamou de normal e que faz parte do desenvolvimento infantil. Neste caso os impulsos destrutivos são atenuados ou neutralizados. O segundo trata-se de um tipo de fusão patológica e que determina a intensificação dos impulsos destrutivos.

No narcisismo destrutivo Rosenfeld, observa um aspecto que ele considera relevante: o fato de que as partes destrutivas e onipotentes estão idealizadas. Ele diz: "Estas se dirigem contra qualquer relação de objeto libidinal positiva, e contra qualquer parte libidinal do self que tem necessidade de um objeto e que deseja depender dele. As partes onipotentes destrutivas do self frequentemente permanecem disfarçadas, ou podem ser silenciosas e estar excindidas, o que obscurece a sua existência e nós dá a impressão de que não têm nenhum relacionamento com o mundo externo. Na verdade, elas exercem um efeito muito poderoso ao impedir relações objetais dependentes e manter os objetos externos permanentemente desvalorizados, o que é responsável pela aparente indiferença 
do indivíduo narcisista em relação aos objetos externos e ao mundo.” (Rosenfeld, 1991,p.250)

Joseph (1975) também descreve sobre um tipo de paciente com os mais diversos diagnósticos, para os quais as interpretações não têm efeito. Ela acrescenta que é muito difícil oferecer a estes pacientes a compreensão emocional verdadeira.

A maneira pela qual os autores acima descrevem certos pacientes em relação às dificuldades para elaboração do luto e à resistência para qualquer tipo de mudança e tratamento, pode ser aplicada aos pacientes diabéticos com controle glicêmico ruim.

Heleno (1992), em um estudo com pacientes diabéticos do tipo 2, mostra que os pacientes de mau controle apresentam uma constelação específica na qual predominam as dificuldades para aceitar a doença, para estabelecer vínculos, para suportar as situações de perda e para elaborar o luto.

O fato de o paciente negar os sintomas do diabetes é de tal forma intenso que muitos abdicam do tratamento médico. Outros não se conformam com o fato de terem uma doença crônica. Negrato et al. (1999) mostra que é cada vez mais comum a busca de tratamentos milagrosos como Auto-cura, Heick, Iridologia, entre outros. O mais grave é que estes pacientes, em função desta opção, podem chegar à morte. No caso dos pacientes tipo 1, de forma aguda. No tipo 2, em decorrência das complicações crônicas prematuras, em virtude da falta de controle glicêmico.

Estes pacientes diabéticos parecem não se dar conta do que se passa com eles e vivem como se o não tratamento fosse algo bom. Além disto, sentem-se protegidos, pois têm a convicção de que nada irá acontecer-lhes. Eles garantem que não sentem nada, nenhum sinal de complicação aguda ou crônica.

Pensamos que esta proteção "perversa” pode ser compreendida a partir do estudo das “organizações patológicas”. Elas oferecem grandes resistências às mudanças e às experiências de dependência de objeto. 
Godoy (1994) mostra que as organizações patológicas podem aparecer em qualquer pessoa e em qualquer momento da vida psíquica. Mas o efeito avassalador observado após o diagnóstico do diabetes mellitus e no curso da vida de alguns pacientes diabéticos leva-nos a pensar se este não seria um campo propício para a ação destas organizações. Alguns diabéticos selam um compromisso de morte na medida em que não podem fazer um tratamento eficaz. São pacientes que levam uma vida improdutiva e de grande sofrimento físico e psíquico, pois as complicações agudas são constantes e as crônicas, prematuras. Este quadro, entretanto, não é visto pelos pacientes desta maneira todo o tempo. Eles vivem em um estado no qual o prejuízo não é observado. Geralmente eles nem se lembram de diabetes, vivem como se não possuíssem tal disfunção. Os altos níveis glicêmicos que ocorrem no dia-a-dia não são detectados pelo paciente. A intensa angústia só emerge em momentos de grande dificuldade, como uma complicação crônica irreversível.

Alleyne (1987) a partir de entrevistas realizadas com pacientes diabéticos em tratamento por complicações crônicas, conclui que apenas depois de experienciarem uma crise, estes pacientes tiveram a percepção da seriedade de sua doença e, neste período, melhoraram significativamente a aderência ao tratamento.

Em “Uma teoria dos refúgios psíquicos”, Steiner (1997) descreve um tipo especial de organização defensiva, denominada “organizações patológicas da personalidade”, que leva o paciente à idéia de que ele pode evitar a angústia insuportável. Este grupo de defesas altamente rígidas, “ajudam” o paciente a fugir da ansiedade e, em contrapartida, o leva à perda de contato com as pessoas e com a realidade. As defesas se organizam de tal modo que o paciente torna-se incapaz de qualquer mudança psíquica. Este fenômeno ocorre em função da impossibilidade do indivíduo de renunciar ao objeto e aceitar esta nova realidade. Nestas ocasiões, nas quais o ego vive a experiência de perda como algo insuportável, as “organizações patológicas” são colocadas em ação para evitar a suposta catástrofe da perda.

A ação destas organizações defensivas cria na mente do indivíduo o que Steiner nomeou de “refúgio psíquico”. É um estado mental no qual a realidade não precisa ser encarada, predominando a onipotência e a fantasia, e onde tudo é permitido. Estes 
refúgios têm grande poder de ação sobre os indivíduos, pois trazem a ilusão de proteção contra a angústia, embora envolvendo mecanismos perversos ou psicóticos. O refúgio é basicamente um "lugar" onde existe apenas estagnação. As partes saudáveis do ego podem tentar emergir desta situação e para que isto ocorra faz-se necessário o confronto com a situação de perda e as angústias dela decorrentes.

Steiner (1997), ao definir as organizações patológicas, nos mostra a importância de observarmos dois aspectos. O primeiro refere-se ao fato de que traumas e privações na vida do indivíduo têm influência decisiva na gênese das organizações patológicas da personalidade. O segundo trata-se de compreender as configurações das posições esquizoparanóide e depressiva e do interjogo entre elas. Para ele, nas transições entre e no interior destas posições se estabelecem pontos nos quais o paciente está vulnerável ao surgimento e ação das organizações patológicas.

Analisando desta forma, Steiner parece referir-se ao fato de que a destrutividade dessas organizações é primária e ao, mesmo tempo, defensiva. Os impulsos destrutivos provenientes da pulsão de morte são projetados em um objeto e este transforma-se em perseguidor. Para dar conta desta perseguição, considerando sua natureza extrema, um sistema de defesa é criado e, apesar de seu caráter perverso, é idealizado.

Steiner , como vimos acima, considera o estudo das posições esquizoparanóide e depressiva de fundamental importância para a compreensão das organizações patológicas. Da mesma forma consideramos os estudos de Bleger (1967). Ele apresenta a hipótese da existência de uma posição, anterior à esquizoparanóide, que ele chamou gliscro-cárica. Esta posição também é caracterizada por desejos inconscientes, medos, ansiedades, defesas e relações de objetos específicas. Assim, da mesma forma faz-se necessário a compreensão das configurações desta posição, para investigar a maneira pela qual ela pode influir ou não na gênese das organizações patológicas.

\section{F.1 - AS POSIÇÕES VISCOCÁRICA, ESQUIZOPARANÓIDE E DEPRESSIVA}


Klein (1952) em “Algumas Conclusões Teóricas sobre a Vida Emocional do Bebê" afirma que nos primeiros meses de vida, o bebê, apesar de possuir um ego pouco estruturado, é capaz de estabelecer relações de objeto. Baranger (1977) estudando o conceito de objeto na obra de Melanie Klein, mostra que estes fazem parte de uma constelação de fenômenos chamada posição e só podem ser entendidos dentro desta dinâmica. Posição implica numa maneira particular do ego estabelecer relações objetais.

Klein (1946) em "Notas sobre alguns mecanismos esquizóides" trata da importância das ansiedades primitivas e dos mecanismos esquizóides e paranóides no desenvolvimento do ego. As ansiedades primitivas, provenientes do instinto de morte, ameaçam o ego pouco estruturado, que defende-se através de mecanismos primitivos como a identificação projetiva, clivagem do objeto e dos impulsos, idealização, escotomização, caracterizando a posição esquizoparanóide.

Na posição depressiva ( Klein, 1946) ocorre uma maior integração do ego, os objetos são reconhecidos como totais e deriva desta situação a ambivalência. O seio frustrador é o mesmo seio que traz a satisfação. Deste fato resultam os sentimentos de perda e culpa. A possibilidade de lidar com esta nova experiência, reconhecer que o objeto existe separado do ego, reconhecer a dependência e a impossibilidade do controle sobre o objeto é uma etapa a ser elaborada dentro da posição depressiva e constitui o trabalho de luto. A diminuição dos processos de clivagem e a maior integração do ego permitem que os mecanismos de repressão sejam utilizados. Gradualmente os mecanismos neuróticos tomam o lugar dos mecanismos psicóticos. Após a superação do luto normal, os mecanismos de defesa como a repressão, o deslocamento e a sublimação, pertencentes à posição depressiva, podem ser mobilizados. A possibilidade da superação do luto, segundo Simon (1989), torna a pessoa mais enriquecida, mais tolerante e sábia. Resulta desta formulação a importância da superação das perdas.

As mudanças de uma posição à outra, consideradas como processos transitórios, dinâmicos e normais, correlacionam-se à alteração na integração dos objetos e do ego. Este processo ocorre em função de mecanismos defensivos como a clivagem e o splitting. 
A redução, na intensidade, destes leva a uma maior integração do ego e à passagem da posição viscocárica para a esquizoparanóide e à depressiva. Soiffer (1992) analisa as defesas como um processo útil na medida em que elas estão destinadas ao cuidado da vida. Assim, ela considera que “ ...as defesas são em princípio normais, ou seja, estão a serviço da saúde. A sua utilização, seja quanto à oportunidade, intensidade e consequências, dará a delimitação entre o normal e o patológico” ( Soiffer, 1992, p.183).

Em contrapartida, o recuo à posição esquizoparanóide ocorre em virtude da impossibilidade do ego suportar a angústia depressiva e a culpa. A diferença fundamental entre as posições é a crescente integração do ego e das relações objetais. Com relação à posição viscocárica, ela emerge no momento em que a separação do objeto não pode ser suportada e o ego lança mão da simbiose como um meio para aplacar a terrível angústia catastrófica.

Na posição viscocárica existe a luta para separar-se do objeto fazendo emergir o ego. Na esquizoparanóide existe a luta contra o medo de aniquilamento, enquanto na depressiva o ego necessita reconhecer a dependência em relação ao objeto e a possibilidade de sobrevivência sem ele. Simon (1986) lembra que a possibilidade de integração do ego e do objeto é possível principalmente pela capacidade do ego para tolerar a angústia.

A dinâmica entre as posições levou Bion (1963) a utilizar um modelo E/P $\leftrightarrow$ D (esquizoparanóide $\leftrightarrow$ depressiva), sugerindo que existe uma flutuação entre dois estados de integração da mente e do conhecimento, necessários para haver evolução: decompor o conhecido-destruição/decomposição, para recompor o novo-construção/recomposição. Através deste modelo notamos que as mudanças podem ser em qualquer uma das direções, incluindo a posição viscocárica. As posições viscocárica, esquizoparanóide e depressiva são diferenciadas, mas deve-se ter o cuidado de não concebê-las como situações estanques e definitivas. 
Para Steiner (1997) o refúgio é uma terceira posição a ser colocada no modelo proposto por Bion. Ele descreve da seguinte maneira: "Embora muito diferente das duas posições básicas, o refúgio funciona em relação a elas, como se ele próprio fosse, na verdade, uma posição. Assim, como as posições esquizoparanóide e depressiva, ele pode ser considerado como um agrupamento de ansiedades, defesas e relações objetais, mas sua estrutura é marcada pela rigidez conferida pelas organizações patológicas da personalidade” ( Steiner, 1997, pág.46).

A diferenciação entre as posições é clara. Mas, em função da complexidade no uso das defesas, analisando níveis mais profundos dos mecanismos mentais, existe também uma distinção de níveis dentro das organizações, tanto nas posições viscocárica e esquizoparanóide quanto na depressiva. Podemos destacar, por exemplo, a clivagem, que na posição esquizoparanóide pode ser de natureza patológica como a descrita por Bion (1957) ou como foi descrita por Klein (1946), cuja natureza é normal.

Esta questão aparentemente contraditória é esclarecida por Simon (1986), que mostra a necessidade de diferenciar as configurações da posição esquizoparanóide: “a posição esquizoparanóide como etapa normal do desenvolvimento de qualquer ser humano; a posição esquizoparanóide como ponto de fixação da psicose esquizofrênica e de personalidades esquizóides (patologia); e a posição esquizoparanóide como momento de regressão temporária no funcionamento de personalidades não-psicóticas (inclui os ditos “normais”)" (Simon, 1986, p.85)

No desenvolvimento infantil, a clivagem é de grande importância para o bebê estruturar, mesmo de forma primitiva, o ego. Quando o ego é capaz de tolerar a ambivalência, provocada pela integração do objeto, começa a emergir a posição depressiva. Entretanto, a ameaça psíquica com a qual se defronta o ego, mesmo em indivíduos saudáveis, não é totalmente atenuada com a clivagem normal. O ego lança mão de defesas mais extremas, poderosas e rígidas que, de um lado atenuam a angústia do aniquilamento, mas de outro têm efeitos prejudiciais. Quando a angústia é sentida 
como insuportável o ego fragmenta-se em partículas que são expelidas de forma violenta. Estes fragmentos levam à formação de objetos bizarros descritos por Bion (1957).

Estes acontecimentos fazem parte do desenvolvimento do ego e geram extrema angústia, que pode ser tolerada com a recuperação da clivagem normal e, consequentemente, das experiências com um objeto bom.

Nos casos em que a recuperação da clivagem normal não é possível e por causa da inveja o bom objeto é atacado, estabelece na mente o caos. Na ausência do objeto bom, o ego pode recorrer às organizações patológicas como único recurso para contenção da angústia persecutória. Para Steiner “as organizações patológicas são especialmente empregadas para se lidar com as ansiedades que surgem na fase da fragmentação patológica. Cisão e fragmentação excessivas, com ansiedade catastrófica, em que o self é sentido como estilhaçando e se desintegrando, podem ser tão insuportáveis que são necessárias organizações defensivas para criar algum tipo de ordem a partir do caos. Nesses estados desesperadores, até as organizações onipotentes com características psicóticas podem fornecer alívio” ( Steiner, 1997, pág. 48)

A clivagem não ocorre apenas em relação ao objeto parcial na posição esquizoparanóide mas também na posição depressiva em relação ao objeto total. A tentativa de manter controlado o objeto bom, protegê-lo e evitar sua perda, faz novamente emergir a clivagem. Suportar a perda do controle sobre o objeto e consequentemente reconhecer sua independência é um problema a ser enfrentado nesta posição.

Esta luta do ego para separar-se do objeto e suportar a perda do controle sobre o mesmo foi tema de reflexão para Bleger (1967) em Simbiose e Ambiguidade. Neste livro, mais precisamente no capítulo 2, o autor defende a possibilidade de haver, antes da posição esquizoparanóide, uma outra posição denominada gliscro-cárica.

Assim como Rosa (1995) e Godoy (1994) utilizaremos a denominação latina, viscocárica, para o termo glyschro-cárica. 
Esta posição tem como característica principal um tipo de relação objetal permeada pela viscosidade e em consequência pela indiscriminação dos objetos e do ego. Rosa (1995) mostra que na posição viscocárica não existe discriminação entre eu e não eu e que a fusão é utilizada de forma intensa numa indiferenciação primitiva. Segundo Bleger, este tipo de vínculo estabelecido com um objeto aglutinado pode ser encontrado na simbiose, na epileptoidia, nos bloqueios afetivos intensos, nos sonhos e nas reações terapêuticas negativas, muito presentes em pacientes diabéticos sem aderência ao tratamento. O desejo é de permanecer fundido ao objeto e diferentemente da posição depressiva, não existe discriminação. Com relação à posição esquizoparanóide, a tendência é de fragmentação, enquanto que na viscocárica é de aglomeração. Este objeto aglutinado é imobilizado e, portanto, passível de controle bastante rígido. Sua origem é primitiva e ele forma-se a partir da relação do ego com objetos internos e partes da realidade exterior.

Este tipo de relação objetal promove angústia catastrófica gerada, não por um objeto mau, mas por objetos parciais que foram condensados e não podem ser reconhecidos. A angústia catastrófica que emerge é atenuada por mecanismos defensivos, muito mais intensos e poderosos do que os das posições esquizoparanóide e depressiva, como dissociação, condensação e imobilização. Estas defesas de grande intensidade aparecem de forma violenta e maciça. Bleger diz: “A ansiedade paranóide pode funcionar como sinal de alarma, o mesmo não ocorrendo com a ansiedade catastrófica provocada pela ameaça de um objeto aglutinado cuja imobilização e controle se tenha perdido, sendo que neste último caso a reação é maciçamente desorganizadora; frente à ansiedade paranóide, podem ser utilizadas defesas paranóides, ao passo que, frente à ansiedade catastrófica, provocada pelo objeto aglutinado, não há tal possibilidade. É evidente que estamos falando de situações - tipo, deixando de lado as variações de grau e transições.” (Bleger, 1985, p.52)

Rey (1979), analisando um paciente borderline, descreve um quadro muito parecido com o que Bleger apresenta na posição viscocárica. Ele escreve: “O medo de se 
separar do objeto e o desejo de penetrar dentro dele e fundir-se numa unidade primitiva podem ser tão intensos que ultrapassam a compreensão humana.” ( Rey, 1991, p. 213)

Assim como as posições esquizoparanóide e depressiva, a posição viscocárica faz parte do desenvolvimento normal do ego e pode emergir em momentos de crise. Isto ocorre pelo fato de que certos núcleos aglutinados poderiam permanecer ativos na personalidade. A questão está centrada na capacidade do ego para discriminar o objeto aglutinado, reintrojetá-lo e, assim, passar à posição esquizoparanóide. “O vínculo simbiótico é uma relação muito condensada de coisas altamente complexas e contraditórias, que precisam ser 'esmiuçadas' e discriminadas para que possam ser reintrojetadas e elaboradas”.(Bleger, 1985, p. 51)

Desta forma, podemos conceber a posição viscocárica influindo no desenvolvimento do ego, de forma normal ou patológica. “ O splitting ocorre na posição viscocárica, para separar ou preservar o ego do objeto aglutinado, e também para operar contra o próprio objeto aglutinado, para fragmentá-lo ou separar uma parte dele, com fins de controle e imobilização, ou ainda para permitir sua posterior elaboração”. (Bleger, 1985, p. 56 )

Na medida em que o objeto aglutinado não pode ser fragmentado e discriminado a posição viscocárica não pode ser desmantelada. Assim, em vez de servir para estruturar o campo para a posição esquizoparanóide, pode servir como meio para a instalação de um refúgio psíquico, com o intuito de preservar o ego da dor psíquica proveniente da cisão ou fragmentação. Godoy (1994), a partir do estudo de um caso, levanta a hipótese da existência de uma organização patológica que teria sua origem na posição viscocárica. Ela diz: "Foi através das vicissitudes ocorridas durante o acompanhamento do caso escolhido para este trabalho, que levantei a hipótese da existência de uma organização patológica que poderia começar num momento muito primitivo da vida de um indivíduo, com a função de organizar o caos em que se encontrava, mas que acabava tendo a função de paralisar seu desenvolvimento em direção à posição esquizoparanóide, pelo tipo de defesas maciças, em blocos, sem permitir discriminação”. (Godoy, 1994, p. 35) 
Desta maneira, o desenvolvimento psíquico ocorre na passagem pelas posições e na superação destas. Mas, longe de ser algo estático, existe uma dinâmica característica para cada posição. As dificuldades que são apresentadas em cada uma delas, tanto para elaborar cada uma delas como para ultrapassá-las. Quando a angústia não pode ser superada pode ocorrer uma paralisação ou então o ego fragilizado retoma a posição anterior.

Este processo gera ansiedade e dor mental, referentes a duas situações. A primeira está relacionada ao temor da perda do objeto e a segunda à experiência da perda do objeto. Steiner (1997) coloca estas situações como dois níveis dentro da posição depressiva. A vivência de perda pode ser de tal forma temida, que o sentimento de perda acaba sendo negado, não havendo possibilidade de elaborar o luto, pois não houve perda. Mas se o ego, apesar da angústia, é capaz de experimentar o sentimento e a vivência da perda, tolerar a frustração, reconhecer a finitude do objeto, poderá superar o luto. A contradição reside no fato de que embora identificado projetivamente com o objeto, e estando certo de que perecerá com ele, o ego necessita renunciar ao objeto. Esta é a maneira pela qual o ego pode recuperar suas partes perdidas, com a reversão da identificação projetiva.

Steiner (1997) desenvolve a idéia de que há um continuum entre as posições esquizoparanóide e depressiva e propõe subdvisões de cada uma delas.. Ele propõe o seguinte modelo:

Posição esquizoparanóide $\longleftrightarrow$ Posição depressiva

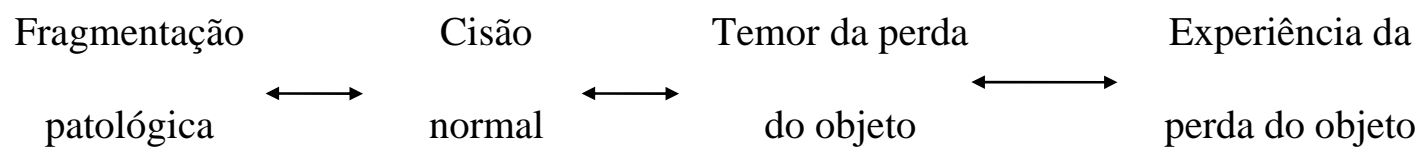

A este modelo acrescentamos a posição viscocárica 


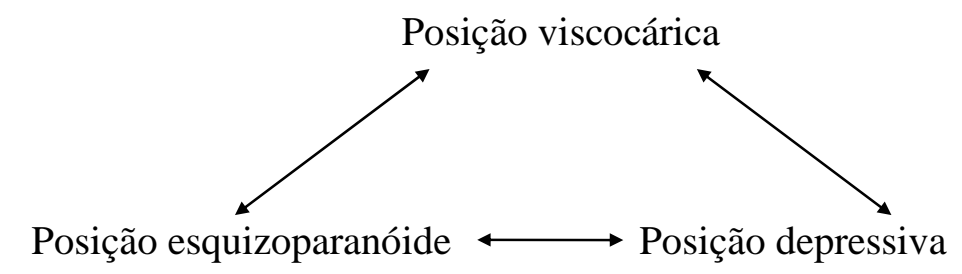

E inclui o refúgio psíquico da seguinte maneira:

Refúgio psíquico

(proteção para não vivência do sentimento de perda)

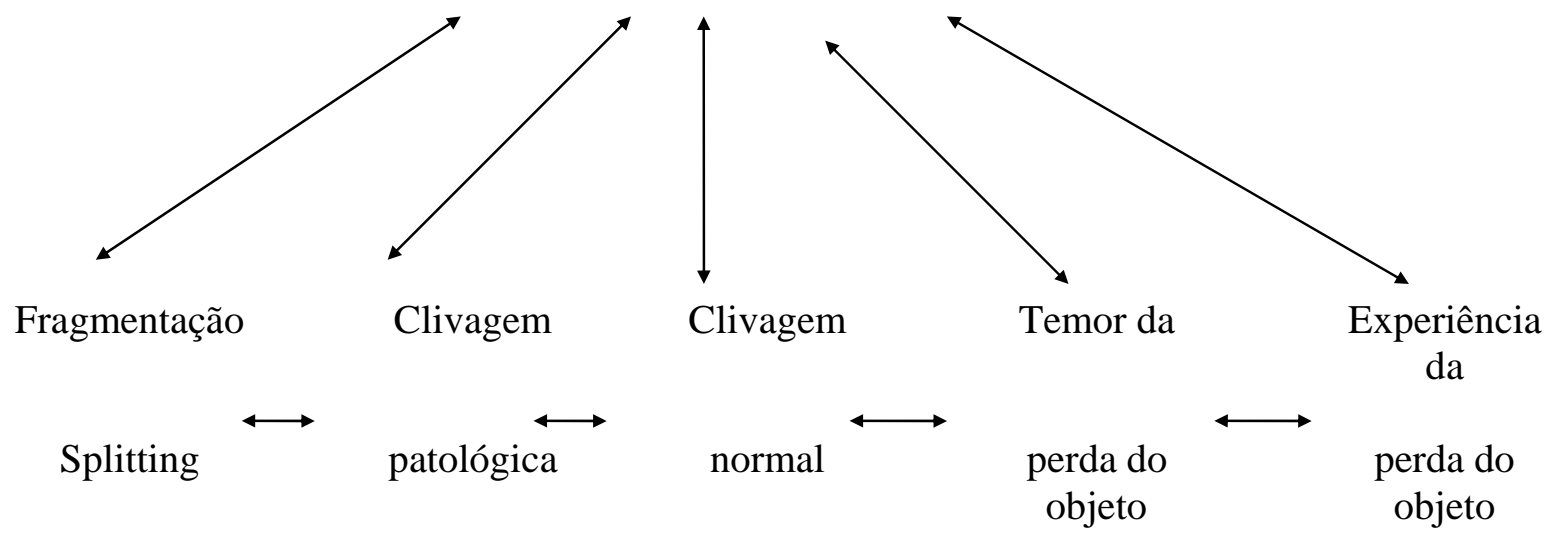

Para Steiner “o paciente pode emergir de um refúgio apenas para retornar à sua proteção, mas as ansiedades com que se confronta também variarão em cada caso. Em pacientes extremamente perturbados, a maior parte do movimento acontece entre o refúgio e os estados de fragmentação patológica. À medida que o desenvolvimento prossegue, outras ansiedades menos aterrorizadoras são enfrentadas, mas pode-se sentir que o refúgio ainda é necessário, se tiver que ser enfrentada alguma dor mental de natureza insuportável, associada ao temor ou à experiência da perda” (Steiner,1997, pág.57).

\section{G - INSTRUMENTOS DE AVALIAÇÃO}

Esta pesquisa pretendeu verificar a presença das organizações patológicas em pacientes diabéticos do tipo 2 e, se presentes, a influência destas no viver diabético, mais objetivamente no controle da glicemia. Optamos por utilizar instrumentos psicológicos 
fidedignos através dos quais pudéssemos analisar a eficácia e o equilíbrio adaptativo do ego, correlacionando-os à presença ou não das organizações patológicas. O controle da glicemia foi determinado através de exames de laboratório.

\section{G.1 - O Teste das Relações Objetais de Phillipson (TRO)}

O Teste das Relações Objetais (TRO) de Herbert Phillipson data de 1955 e possui, segundo Bernstein (apud Phillipson, 1981), uma situação privilegiada dentro das técnicas projetivas. Baseia-se na teoria das relações objetais de Melanie Klein e Fairbain, reunindo características do TAT e do teste de Rorschach. Enquanto o TAT recolhe a projeção através da fantasia e o Rorschach através da percepção, o TRO concilia ambas as tendências. Assim, é um teste de forma e de conteúdo, dinâmico e dramático.

O grau de estruturação do TRO é pequeno e varia em cada série. Esta característica do teste determina que a visão de figuras humanas, animais, com ou sem movimento, bem como seres inanimados, depende exclusivamente do paciente.

Phillipson utiliza como pressuposto básico o fato de que o processo perceptivo é determinado primariamente pelas relações pessoais e, por isso, somente entendido em função delas. Para compreendermos como a percepção das relações pessoais influem na conduta de um indivíduo em uma determinada situação, devemos levar em conta que o mundo interno das relações objetais determina de modo fundamental as relações do indivíduo com as pessoas do mundo externo. A conduta manifesta representa a tentativa de conciliação das formas inconscientemente reprimidas de relacionar-se que foram fantasiadas como meio de gratificação ou ataque e a experiência de relações acumuladas mais conscientes que foram por um longo período passadas pelo crivo da realidade externa.

O TRO explora os aspectos conscientes e inconscientes. Os aspectos manifestos são avaliados através do conteúdo humano e de realidade e do contexto de realidade que evocam ou intensificam diferentes tipos e níveis de sentimentos. Os aspectos inconscientes são explorados através do triângulo formado por desejos, medos e defesas. Na avaliação do Sistema Tensional Dominante Inconsciente Dominante (STID), através do qual pensamos elucidar e analisar a ação das organizações patológicas, podemos compreender a dinâmica do mundo interno; a natureza dos relacionamentos objetais 
inconscientes; a possibilidade de modificação de vínculos patológicos; os diferentes tipos e níveis de organização de vínculos e sistemas defensivos frente a diversas situações, estas reveladas por lâminas em três séries com um, dois, três e vários personagens.

Na série A, as lâminas são pouco estruturadas, deixando a imaginação do paciente livre. Explora as primeiras relações de objetos de dependência e sua relação com o contato físico e sensitivo. Evoca primitivas necessidades de relações objetais e ansiedades referentes à sua satisfação. Nesta série espera-se o surgimento da ansiedade de tipo depressivo, a diminuição das defesas onipotentes e a substituição destas pelas de controle obsessivo. Neste caso, teríamos um paciente com um bom índice de adaptação.

A série B apresenta lâminas onde as figuras possuem traços definidos em relação ao conteúdo de realidade. Por esse motivo, o paciente tem pouca liberdade para interpretar a prancha. Através desta série pode-se avaliar o grau de adaptação à realidade. Em suma, podemos observar a capacidade do ego para lidar com a realidade em função da boa estruturação das figuras. As angústias mobilizadas podem ser atenuadas através de defesas neuróticas.

O cenário apresentado nas pranchas da série C é mais rico em detalhes e menos definido do que a série B. A inclusão da cor aumenta a tensão e os sentimentos agressivos entre o indivíduo e o grupo. Esta série possibilita a apreciação do tipo de vínculo que o paciente estabelece com seus objetos. De maneira geral, devem prevalecer, nesta série, as defesas neuróticas.

As histórias produzidas pelos pacientes diabéticos, a partir das pranchas do TRO, serão analisadas através do STID embasado no modelo das Relações Objetais de Melanie Klein. As relações estabelecidas com os objetos caracteriza e determina as posições, que podem ser esquizoparanóide e depressiva. Na primeira, o desejo é de preservar o objeto bom, mantendo-o afastado dos objetos ruins. As angústias referem-se basicamente ao medo do aniquilamento, sentimentos de inveja do objeto bom e medo do progresso. As defesas apresentadas são divisão, idealização, identificação projetiva e de anulação da inveja. Na posição depressiva a tentativa é de reparar os danos resultantes dos ataques aos objetos bons. A angústia é depressiva e a luta é para superar a culpa pela destruição do objeto. As defesas são de negação, controle obsessivo e as reparações maníacas. 
Rosa (1995) inclui no STID a posição Viscocárica descrita por J. Bleger (1967) em Simbiose e Ambigüidade. Nesta posição existe o predomínio da angústia confusional e do medo pela perseguição dos objetos. O desejo é de fusão com um objeto bom e protetor e as defesas apresentadas geralmente são identificação adesiva, paralisação, fragmentação e clivagem.

Assim, através do TRO, poderemos observar as posições e possíveis transições no interior delas. Outro aspecto importante que nos levou a optar pelo uso do TRO deveu-se ao fato de que duas lâminas são particularmente interessantes para os objetivos desta pesquisa. A lâmina AG, que estimula angústia de tipo predominantemente depressivo, explora a capacidade do ego de tolerar e elaborar a situação de perda. A prancha C2 mobiliza angústia frente à situação de morte, doença e velhice. Através desta prancha pode-se avaliar a capacidade de reparação do ego.

Steiner (1997), analisando as organizações patológicas, faz uma indicação de como o paciente descreve o refúgio psíquico. “A visão do paciente a respeito do refúgio reflete-se nas descrições que fornece, e também nas fantasias inconscientes reveladas em sonhos, recordações e relatos da vida diária, que proporcionam uma imagem pictórica ou dramatizada de como o refúgio é experimentado inconscientemente. Tipicamente, ele

aparece como uma casa, caverna, fortaleza ilha deserta ou local semelhante, vistos como área de relativa segurança. Alternativamente, ele pode tomar um forma interpessoal, em geral como uma organização de objetos ou objetos parciais que se propõe a oferecer segurança. Ele pode ser representado como um estabelecimento comercial, um internato, uma seita religiosa, um governo totalitário ou uma gangue de mafiosos. Freqüentemente, ficam evidentes elementos tirânicos e perversos, na descrição, mas algumas vezes a organização é idealizada e admirada.”( Steiner, 1997, pag.18)

Assim, pensamos que as pranchas do TRO servirão como uma tela, na qual o paciente poderá projetar as configurações destes refúgios, da mesma forma que o faz em sonhos, em relatos de sua vida, entre outros, descritos por Steiner. 
Além disso, utilizaremos como referência o trabalho de Grassano (1996) que propõe alguns indicadores psicopatológicos nas técnicas projetivas. Interessou-nos, particularmente, os indicadores no teste das relações objetais de Phillipson (TRO), que tem como objetivo o “diagnóstico de neurose, psicose e psicopatias como configurações clínicas diferenciais, mas também como modos de funcionamento mental que podem coexistir numa mesma personalidade”.(Grassano, 1996, p.77)

A análise dos conteúdos humano e de realidade, do contexto de realidade e do sistema tensional inconsciente dominante, na proposta de Grassano (1996), pode dar a possibilidade de compreensão mais profunda da personalidade do indivíduo.

Os indicadores foram estabelecidos a partir da análise de protocolos do TRO e tem como um dos objetivos “criar critérios explícitos de processamento das respostas projetivas, com fins tanto diagnósticos como prognósticos.”(Grassano, 1996, p. 15).

\section{G.2 - Escala Diagnóstica Adaptativa Operacionalizada - EDAO}

A EDAO, elaborada pelo Dr. Ryad Simon (1989), tem como objetivo identificar a eficácia da adaptação, através da classificação do indivíduo a partir da adequação das respostas que ele apresenta para solucionar as necessidades provocadas por estímulos provenientes do mundo interno e externo. As respostas são avaliadas nos quatro setores de funcionamento do indivíduo. Assim temos:

(1) Afetivo - Relacional (AR): compreende os sentimentos, atitudes e ações do indivíduo com relação a si próprio e ao semelhante;

(2) Produtividade (Pr): relacionado com sentimentos e atitudes do indivíduo frente ao trabalho, estudo ou qualquer atividade produtiva considerada como principal em sua vida; 
(3) Sócio - Cultural (SC): engloba sentimentos, atitudes e ações em relação ao ambiente social, normas, valores e tradições da cultura em que vive;

(4) Orgânico (Or): compreende o estado e funcionamento do organismo, e ainda os sentimentos, ações e cuidados do indivíduo em relação ao próprio corpo.

A avaliação de cada resposta é feita a partir de três possíveis tipos de adequação:

(1) Resposta Adequada (+++): quando proporciona satisfação e não provoca conflitos internos ou externos;

(2) Resposta Pouco Adequada (++): quando a solução proporciona satisfação, mas provoca conflitos internos ou externos, ou não provoca conflitos internos ou externos, mas não traz satisfação;

(3) Resposta Pouquíssimo adequada (+): quando a solução não proporciona satisfação e ainda traz conflitos internos e externos.

A partir desta avaliação temos as seguintes possibilidades:

Adaptação Eficaz - Grupo 1 e Adaptação Ineficaz, subdivida em Grupo 2 - Leve, Grupo 3 - Moderada, Grupo 4 - Severa e Grupo 5 - Grave.

Para Simon (1989) a evolução da adaptação é um processo dinâmico que envolve fatores e micro-fatores internos e externos. Estes são classificados em positivos ou negativos, dependendo do significado que têm para o sujeito. Os positivos conduzem ao aumento da eficácia adaptativa e os negativos à sua diminuição.

A redução da eficácia adaptativa pode ocorrer por crise, que seria provocada por “fatores negativos” ou pela ação cumulativa de "micro-fatores negativos”. Por outro lado, o aumento da eficácia da adaptação resultaria por ação de "fatores” e "micro-fatores positivos”. O conceito de crise tratado nesta pesquisa é o proposto por Simon (1989). 
Desde a sua construção, a EDAO vem sendo utilizada em várias pesquisas psicológicas (Rossini, 1985; Silva, 1989; Leite, 1989; Yoshida, 1989; Heleno,1992; Costa-Rosa, 1995; entre outras), em função de seu valor diagnóstico.

A Entrevista Clínica Preventiva, a partir da qual se faz o diagnóstico operacionalizado, nos foi apresentada em 1987 pelo Prof. Dr. José Tolentino Rosa e desde esta época a utilizamos. Inicialmente como instrumento de pesquisa mas posteriormente, e principalmente, pelo seu valor clínico. Pôde ser constatado na prática que a EDAO é um instrumento rico pela sua flexibilidade e ampliação do conhecimento a respeito do indivíduo. Na prática hospitalar, em nossa experiência de 15 anos no atendimento ao paciente diabético, a EDAO nos tem servido como uma luva, por alguns motivos: 1) O paciente não nos procura no serviço ambulatorial, nós o procuramos. 2) Como não existe queixa nós é que estamos interessados em conhecer melhor o paciente e verificar seus recursos e dificuldades. 3) Não perdemos informações sobre as peculiaridades do indivíduo, rotulando-o em determinada patologia. 4) Não nos estendemos em excesso. 5) Podermos utilizar um sistema de classificação. 6) Através da EDAO podemos fazer uma análise qualitativa e quantitativa. 7) Temos a possibilidade de fazer intervenções e tomar medidas terapêuticas específicas com a utilização do “diagnóstico precoce”. Esta intervenção procura atingir o paciente já “doente”, mas antes que tenha sido alcançado pelos efeitos devastadores decorrentes da doença, como é o caso do diabetes. 8) Fazemos intervenções que ajudam o paciente a esclarecer dúvidas a respeito da convocação, da doença e do atendimento psicológico.

O mais importante é que através da Entrevista Clínica Preventiva o paciente é atendido, acolhido e encaminhado. Posteriormente, se o paciente permitir, como é o caso deste trabalho, podemos utilizar os dados como material de pesquisa.

\section{G.3 - Ficha de Avaliação Sócio - Econômica}


A Avaliação Sócio - Econômica foi utilizada para caracterizar a amostra. Embora os pacientes sejam oriundos de uma mesma instituição pública, faz-se necessária a homogeneidade em relação à classe social. Esta variável foi controlada para evitarmos que as diferenças apontadas entre os grupos comparativos pudessem ser atribuídas a ela.

Como critério para a classificação da classe sócio-econômica utilizamos a proposta da ABIPEME - Associação Brasileira dos Institutos de Pesquisa de Mercado, por ser este um instrumento de indiscutível credibilidade.

\section{G.4 - Controle da Glicemia}

A qualidade do controle glicêmico foi determinada a partir da Glicose plasmática em jejum (GJ), sendo considerado de bom controle o paciente que tenha alcançado valor $\leq 126 \mathrm{mg} / \mathrm{dl}$, conforme recomenda a Sociedade Brasileira de Diabetes (SBD). Contamos também com a medida da glicose plasmática casual (GC), definida, segundo a SBD, como aquela realizada a qualquer hora do dia, sem observar o intervalo da última refeição. É considerado de bom controle o paciente com valores $\leq 200$ mg/dl.

Deixamos de utilizar a Hemoglobina Glicosilada $\left(\mathrm{HBA}_{1}\right)$ pois Dib (1984) concluiu que este exame está mais indicado para pacientes diabéticos do tipo 1. No diabetes do tipo 2, as oscilações dos níveis glicêmicos são menores. Consequentemente, a GJ parece ser instrumento suficiente para determinação da qualidade do controle.

\section{H - OBJETIVOS}

Considerando a importância dos estudos sobre diabetes, o número de pessoas que podem ser beneficiadas e sua dimensão dramática, relatada minuciosamente por Viard (1984), esta pesquisa tem como objetivo identificar e elucidar à ação das organizações patológicas em pacientes diabéticos tipo 2, com mau controle da glicemia, da seguinte maneira: (1) avaliar o grau de eficácia adaptativa e os episódios de crise; (2) avaliar a dinâmica emocional e o equilíbrio adaptativo do ego, visando a compreensão do sistema 
tensional inconsciente principal, que pode identificar, ou não, a presença das organizações patológicas; (3) correlacionar o grau de eficácia adaptativa com a qualidade do controle glicêmico e com presença ou não das organizações patológicas; (4) correlacionar o grau de equilíbrio adaptativo do ego com a qualidade do controle glicêmico e com a presença ou não das organizações patológicas e (5) correlacionar a qualidade do controle glicêmico com a presença ou não das organizações patológicas.

\section{II - MÉTODO}

\section{A - Amostra}

A amostra pertencia à população atendida, no primeiro semestre de 1999, no programa da Liga dos estudantes para o atendimento do paciente diabético (LIGA)*, do Centro de Diabetes da Universidade Federal do Estado de São Paulo (UNIFESP). Foram atendidos113 pacientes. Destes 16 foram excluídos, 7 por serem diabéticos do tipo 1, 4 por apresentarem retinopatia diabética, 01 por ser alcoolista e 4 porque não completaram o controle.

Foram objeto deste estudo 30 pacientes diabéticos do tipo 2, amostra representativa e imparcial, com idade entre 44 e 62 anos, divididos em dois grupos.

O grupo I era formado por 15 pacientes com bom controle glicêmico, sendo 06 do sexo masculino e 09 do sexo feminino. O grupo II tinha 15 pacientes com mau controle glicêmico sendo, também, 06 do sexo masculino e 09 do feminino.

Para determinar a amostra com garantia de que ela fosse representativa e imparcial foi utilizado o critério proposto por Costa (1998).

\footnotetext{
*Agradecemos ao Prof. Ms. Daniel Lerário, coordenador da Liga, por ter permitido a realização deste trabalho.
} 
Os sujeitos pertenciam às classes D e E. O nível sócio econômica foi determinado através dos critérios utilizados pela Associação Brasileira dos Institutos de Pesquisa de Mercado (ABIPEME ). Utilizamos este critério pela sua indiscutível credibilidade. Esta variável foi controlada para evitar que o resultado pudesse ser atribuído às diferenças sócio-econômicas.

\section{B - Recursos Humanos e Materiais}

Os participantes, pacientes diabéticos do tipo 2, foram atendidos individualmente pela pesquisadora e por três psicólogas *, da LIGA, treinadas e familiarizadas com os instrumentos utilizados nesta pesquisa que foram:

1- Ficha de Avaliação Sócio-Econômica (ABIPEME).

2- Escala Diagnóstica Adaptativa Operacionalizada (EDAO).

3-Teste das Relações Objetais de Phillipson (TRO).

*Agradecemos às psicólogas Andreia Luciana Lopes Devide, Priscilla Fernandes M. Santos e Sonia Elias. 
A pesquisa foi realizada no Centro de Diabetes da Universidade Federal do Estado de São Paulo (UNIFESP).

Pelo fato de alguns pacientes diabéticos apresentarem como complicação aguda distúrbios de visão e como complicação crônica a retinopatia diabética, todos foram submetidos a um exame simples de acuidade visual, antes da aplicação do teste projetivo, para que toda resposta dada fosse entendida como resultado da projeção.

\section{C - Procedimentos}

Todos os pacientes da LIGA foram atendidos pela equipe multiprofissional formada por médicos, enfermeiros, nutricionistas e psicólogos. O diagnóstico era feito pelos endocrinologistas, que encaminhavam os pacientes para os outros profissionais da equipe.

A psicologia contava com quatro profissionais incluindo a pesquisadora. Os pacientes eram atendidos individualmente, num total de 3 encontros. No primeiro foi feita a Avaliação sócio-econômica (Anexo I) e a Entrevista Clínica Preventiva, conforme proposta do Prof. Dr. Ryad Simon (1989). Os dados colhidos na Entrevista foram utilizados para a Classificação Diagnóstica (Anexo II). Nesta primeira entrevista explicou-se, também, para o paciente que este material poderia ser usado em uma pesquisa. Foram esclarecidos os objetivos e, caso ele concordasse foi solicitado que assinasse o termo de autorização.(Anexo III). No segundo encontro foi feita a aplicação do Teste das Relações Objetais de Phillipson (Anexo IV). Antes do teste, foi realizado um exame simples de acuidade visual, para garantir que o material colhido referia-se à projeção. E no terceiro encontro foi feita a devolutiva para o paciente.

Todos os pacientes possuíam um prontuário com dados sobre todos os atendimentos e sua evolução. O controle foi realizado por seis meses e para a 
determinação de sua qualidade, foram utilizadas como critério as recomendações da SBD (1999).

A partir deste critério foram definidos os grupos. Os pacientes com glicose plasmática de jejum $<126$ mg/dl e Glicose Casual $<$ 200mg/dl foram considerados de bom controle e formaram o Grupo I. Acima ou igual a estes valores, Grupo II, de mau controle.

Para este estudo, na impossibilidade da utilização da população da LIGA pelo número elevado de pacientes ( Quadro I), optou-se por trabalhar com uma amostra da Quadro I - Classificação dos pacientes diabéticos, por sexo e por controle glicêmico, atendidos na Liga de Estudantes do Centro de Diabetes - UNIFESP(1999)

\begin{tabular}{|c|c|}
\hline Classificação & Quantidade de Pacientes \\
\hline $\begin{array}{c}\text { PMMC } \\
\text { (Paciente masculino com mau controle glicêmico) }\end{array}$ & 20 \\
\hline $\begin{array}{c}\text { PMBC } \\
\text { (Paciente masculino com bom controle glicêmico) }\end{array}$ & 20 \\
\hline $\begin{array}{c}\text { PFMC } \\
\text { (Paciente feminino com mau controle glicêmico }\end{array}$ & 32 \\
\hline $\begin{array}{c}\text { PFBC } \\
\text { (Paciente feminino com bom controle glicêmico }\end{array}$ & 24 \\
\hline $\begin{array}{c}\text { População } \\
\text { (Pacientes considerados para este estudo) }\end{array}$ & $\mathbf{9 6}$ \\
\hline Desistências / Exclusões & 17 \\
\hline Total de pacientes atendidos na Liga no ano de 1999 & 113 \\
\hline
\end{tabular}

população. Para garantir a representatividade e imparcialidade da amostra utilizou-se o seguinte sistema. Os pacientes foram divididos em dois grupos utilizando como critério a variável sexo. Estes dois grupos foram subdividos levando-se em consideração a qualidade do controle. A partir do controle das variáveis sexo e glicemia de jejum e casual definiu-se a amostra (Quadro II). Para garantia da imparcialidade utilizou-se o critério de sorteio dos sujeitos dentro de cada grupo. 
Quadro II - Amostra representativa da população atendida na LIGA de Estudantes do Centro de Diabetes - UNIFESP

\begin{tabular}{|c|c|c|c|c|}
\hline Classificação & $\begin{array}{c}\text { Quantidade de } \\
\text { pacientes }\end{array}$ & Porcentagem & $\begin{array}{c}\text { Amostra } \\
\text { Representativa }\end{array}$ & $\begin{array}{c}\text { Amostra } \\
\text { utilizada }\end{array}$ \\
\hline PMMC & 20 & 20,83 & 2 & 6 \\
\hline PMBC & 20 & 20,83 & 2 & 6 \\
\hline PFMC & 32 & 33,33 & 3 & 9 \\
\hline PFBC & 24 & 25,01 & 3 & 9 \\
\hline TOTAL & 96 & 100,00 & 10 & 30 \\
\hline
\end{tabular}

A análise da eficácia adaptativa (EDAO) e do equilíbrio adaptativo (TRO) foi feitas às cegas, já que a pesquisadora desconhecia a qualidade do controle de cada paciente.

\section{C.1 - Ficha de Avaliação Sócio - Econômico}

Através da Ficha de Avaliação Sócio - econômico (Anexo I) foi determinada a classe social a que pertencia o paciente diabético, para que houvesse homogeneidade da amostra. Sendo assim, a qualidade do controle glicêmico não poderia ser atribuídas a esta variável.

\section{C.2 - Escala Diagnóstica Adaptativa Operacionalizada - EDAO}


Os dados obtidos a partir da Entrevista Preventiva foram avaliados através da EDAO ( Anexo II ). Nesta escala avaliamos o nível da eficácia adaptativa dos participantes. O tipo de resposta dada pelo paciente nos revelou seus níveis de adaptação às situações da vida, além da análise da situação de crise.

Com a utilização desta escala na pesquisa psicológica, temos ainda a vantagem da possibilidade de uma avaliação quantitativa dos dados. Algumas propostas haviam sido formuladas, mas elas mostraram-se falhas, conforme aponta Simon (1996) em um artigo apresentado no II Encontro de Técnicas de Exame Psicológico do IPUSP e publicado em 1998 na Revista Mudanças. Nele, o autor propõe uma redefinição da EDAO, que utilizaremos nesta pesquisa.

A adaptação do indivíduo engloba quatro setores: o afetivo - relacional, produtividade, orgânico e o sócio - cultural. Em princípio, a avaliação tanto qualitativa como quantitativa era feita para os quatro setores igualmente. Na reformulação, o Prof. Dr. Simon, propôs a idéia de trabalhar quantitativamente com os setores afetivo relacional e produtividade. Quanto aos setores orgânico e sócio - cultural, eles serão avaliados qualitativamente. O autor da EDAO parte do pressuposto de que os setores afetivo - relacional e produtividade, ocupam posição de destaque na totalidade adaptativa. Isso vale principalmente para o setor $\mathrm{AR}$, colocado em posição central em relação aos outros setores, o que veio a corroborar descobertas sobre os fatores mais importantes da EDAO, publicados após um estudo estatístico de análise fatorial feito por Gandini (1995). Além disso, as soluções insatisfatórias apresentadas nos setores orgânico e sócio cultural foram detectadas nos setores afetivo - relacional e produtividade. Podemos citar o caso de um paciente diabético com mau controle glicêmico que terá a repercussão deste problema no setor produtividade e afetivo - relacional. Os sintomas decorrentes dos níveis elevados de açúcar no sangue ( sonolência, micções constantes, inclusive noturnas; fome, sensação de fraqueza) impedem ou dificultam a atividade produtiva. Nesta nova proposta, teremos a seguinte classificação: 


\section{Setor Afetivo-relacional (AR)}

Adequado: 3 pontos

Pouco adequado: 2 pontos

Pouquíssimo adequado: 1 ponto

\section{Setor Produtividade (Pr)}

Adequado: 2 pontos

Pouco adequado: 1 ponto

Pouquíssimo adequado: 0,5 ponto

Para nomear as situações de crise, foi acrescentado ao número do grupo a letra C. Assim, um paciente com Adaptação Ineficaz Leve em Crise, será classificado como 2-C.

A partir da redefinição da Escala Adaptativa Operacionalizada -EDAO, os cinco grupos serão definidos da seguinte maneira:

\section{Grupo 1}

\section{Adaptação Eficaz}

AR adequado + Pr adequado $(3+2)=5,0$ (cinco pontos)

\section{Grupo 2}

\section{Adaptação Ineficaz Leve:}

AR pouco adequado + Pr adequado $(2+2)=4,0$ (quatro pontos)

AR adequado + Pr pouco adequado $(3+1)=4,0$ (quatro pontos)

\section{Grupo 3}

\section{Adaptação Ineficaz Moderada}

AR pouco adequado + Pr pouco adequado $(2+1)=3,0$ (três pontos)

AR adequado + Pr pouquíssimo adequado $(3+0,5)=3,5$ (três pontos e meio)

AR pouquíssimo adequado $+\operatorname{Pr}$ adequado $(1+2)=3,0$ (três pontos)

\section{Grupo 4}




\section{Adaptação Ineficaz Severa}

AR pouquíssimo adequado + Pr pouco adequado $(1+1)=2$ ( dois pontos)

AR pouco adequado + Pr pouquíssimo adequado $(2+0,5)=2,5$ (dois pontos e meio)

\section{Grupo 5}

\section{Adaptação Ineficaz Grave}

AR pouquíssimo adequado + Pr pouquíssimo adequado $(1+0,5)$ = 1,5 ( 1 ponto e meio)

Os dados desta pesquisa foram tratados a partir desta proposta de redefinição da EDAO.

\section{C.3 - O Teste das Relações Objetais de Phillipson - TRO}

A análise das histórias do TRO (Anexo III), através do Sistema Tensional Inconsciente Dominante (STID), foi feita a partir do modelo das Relações Objetais de Melanie Klein. Serão analisados os medos, as defesas e desejos. Assim, conforme sugere Phillipson ( 1981), através da análise desta tríade podemos compreender a dinâmica do mundo interno. A maneira pela qual uma pessoa estabelece suas relações pessoais no presente é o produto de seu manejo das primeiras relações objetais.

Rosa (1995) mostra que, segundo o modelo das Relações Objetais de Melanie Klein, as relações estabelecidas com os objetos formam constelações que caracterizam as posições que podem ser, Esquizoparanóide e Depressiva. Além destas duas posições, ele utiliza outro modelo, este proposto por Bleger (1967), incluindo uma terceira posição, denominada Viscocárica. O estudo e identificação das posições, através das histórias do TRO, nos deu indícios da presença ou não das organizações patológicas.

A análise da dinâmica do mundo interno através do Teste das Relações Objetais de Phillipson (TRO) foi feita, qualitativamente e quantitativamente (Quadro III). A utilização de uma escala ordinal para atribuição de pontos no STID, em substituição à graduação proposta por Phillipson, foi utilizada inicialmente em um estudo de caso sobre 
dois pacientes depressivos (Rosa, 1988). Posteriormente, foi usada por Silva (1988), Leite (1989) e Heleno (1992).

\section{Quadro III - Classificação e seriação do equilíbrio adaptativo no TRO}

\begin{tabular}{|c|c|l|}
\hline $\begin{array}{c}\text { Classificação } \\
\text { (Phillipson) }\end{array}$ & $\begin{array}{c}\text { Seriação } \\
\text { (Rosa) }\end{array}$ & \multicolumn{1}{|c|}{ Descrição das Categorias } \\
\hline$(--)$ & 1 & $\begin{array}{l}\text { Equilíbrio não mantido, predominando a ansiedade } \\
\text { com relações muito negativas }\end{array}$ \\
\hline$(-)$ & 2 & $\begin{array}{l}\text { Equilíbrio não mantido, predominando a ansiedade, } \\
\text { com relações negativas }\end{array}$ \\
\hline$\left(0^{-}\right)$ & 3 & Tendência adaptativa com resultante negativa \\
\hline$($ o $)$ & 4 & $\begin{array}{l}\text { Equilíbrio mantido podendo dar liberdade para } \\
\text { relações positivas }\end{array}$ \\
\hline$\left(0^{+}\right)$ & 5 & Tendência adaptativa com resultante positiva \\
\hline$(+)$ & 6 & Liberdade para estabelecer relações positivas \\
\hline$(++)$ & 7 & Liberdade para estabelecer relações muito positivas \\
\hline
\end{tabular}

\section{III - RESULTADOS e DISCUSSÃO}

\section{A. Análise comparativa dos resultados apresentados por trinta pacientes diabéticos} do tipo 2, divididos em Grupo I, de bom controle, e Grupo II, de mau controle.

Este estudo teve como objetivo verificar a eficácia adaptativa (EDAO), o equilíbrio interno do ego (TRO) e o controle glicêmico(G) em pacientes diabéticos do tipo 2 e estabelecer as possíveis correlações entre estas variáveis e a presença ou não das organizações patológicas.

A qualidade do controle glicêmico foi determinado a partir das médias das Glicemias de Jejum (GJ) e das médias das Glicemias Casuais (GC). Os pacientes diabéticos que apresentaram as GJ $<126$ mg/dl e Glicose Casual < 200mg/dl foram 
considerados de bom controle e formaram o Grupo I (Gr I). Acima ou igual a estes valores, Grupo II (Gr II), de mau controle.

Tabela 1 - Pacientes diabéticos com bom controle glicêmico - Gr I

\begin{tabular}{|l|l|l|c|l|l|l|l|l|}
\hline Sujeito & GC & GJ & Sujeito & GC & GJ & Sujeito & GC & GJ \\
\hline $\mathbf{N 2 9}$ & 120 & 115 & $\mathbf{N 1 5}$ & 116 & 103 & $\mathbf{N 1 9}$ & 107 & 104 \\
\hline $\mathbf{N 2 8}$ & 104 & 121 & $\mathbf{N 1 3}$ & 117 & 118 & $\mathbf{N 0 9}$ & 097 & 117 \\
\hline $\mathbf{N 1 7}$ & 139 & 112 & $\mathbf{N 1 6}$ & 120 & 109 & $\mathbf{N 0 5}$ & 108 & 119 \\
\hline $\mathbf{N 2 7}$ & 109 & 104 & $\mathbf{N 3 0}$ & 119 & 114 & $\mathbf{N 0 7}$ & 100 & 116 \\
\hline $\mathbf{N 2 6}$ & 102 & 104 & $\mathbf{N 2 0}$ & 115 & 111 & $\mathbf{N 2 1}$ & 116 & 113 \\
\hline
\end{tabular}

Amostra de Pacientes Diabéticos com Bom Controle - Gr I

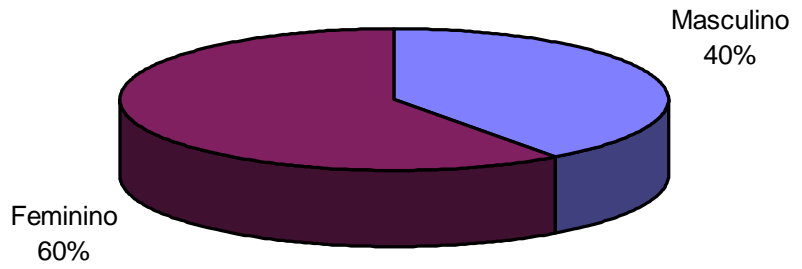

Figura 1

Tabela 2 - Pacientes diabéticos com mau controle glicêmico - Gr II

\begin{tabular}{|c|l|l|c|l|l|c|l|l|}
\hline Sujeito & GC & GJ & Sujeito & GC & GJ & Sujeito & GC & GJ \\
\hline N10 & 204 & 286 & $\mathbf{N 2 3}$ & 249 & 287 & N08 & 361 & 346 \\
\hline $\mathbf{N 2 5}$ & 213 & 240 & $\mathbf{N 2 4}$ & 224 & 253 & $\mathbf{N 0 6}$ & 249 & 191 \\
\hline $\mathbf{N 1 2}$ & 250 & 256 & $\mathbf{N 2 2}$ & 218 & 213 & $\mathbf{N 0 3}$ & 398 & 274 \\
\hline $\mathbf{N 1 1}$ & 246 & 271 & $\mathbf{N 1 4}$ & 227 & 259 & $\mathbf{N 0 2}$ & 281 & 272 \\
\hline $\mathbf{N 0 1}$ & 280 & 333 & $\mathbf{N 1 8}$ & 285 & 216 & $\mathbf{N 0 4}$ & 222 & 261 \\
\hline
\end{tabular}




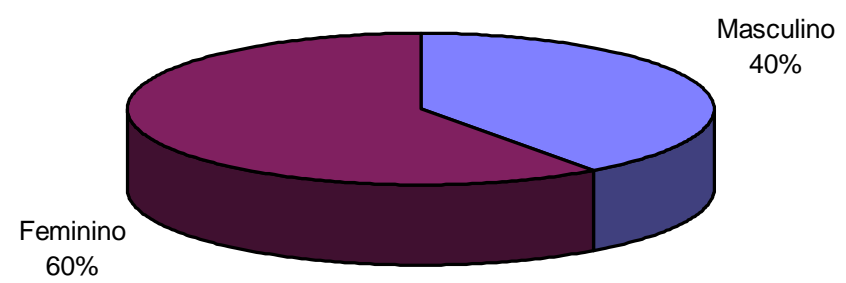

Figura 2

A.1 - Análise comparativa da eficácia adaptativa em pacientes diabéticos tipo 2, divididos em Gr I, de bom controle, e Gr II, de mau controle glicêmico.

Analisando a eficácia adaptativa dos grupos I e II, através de parâmetros estatísticos, observamos que existe forte correlação entre a qualidade do controle glicêmico e a eficácia adaptativa. Assim, quanto melhor o nível da eficácia adaptativa melhor o controle glicêmico.

Tabela 3 - Eficácia Adaptativa em pacientes diabéticos com bom controle glicêmico -

Grupo I

\begin{tabular}{|c|c|l|}
\hline Sujeito & Total de Pontos & \multicolumn{1}{|c|}{ Classificação Diagnóstica } \\
\hline N29 & 05 & Adaptação Eficaz \\
\hline N28 & 05 & Adaptação Eficaz \\
\hline N17 & 05 & Adaptação Eficaz \\
\hline N20 & 05 & Adaptação Eficaz \\
\hline N21 & 05 & Adaptação Eficaz \\
\hline N15 & 05 & Adaptação Eficaz \\
\hline N13 & 05 & Adaptação Eficaz \\
\hline
\end{tabular}




\begin{tabular}{|l|l|l|}
\hline N16 & 05 & Adaptação Eficaz \\
\hline N30 & 05 & Adaptação Eficaz \\
\hline N27 & 04 & Adaptação Ineficaz Leve \\
\hline N07 & 04 & Adaptação Ineficaz Leve \\
\hline N26 & 04 & Adaptação Ineficaz Leve - Crise \\
\hline N19 & 04 & Adaptação Ineficaz Leve - Crise \\
\hline N09 & 03 & Adaptação Ineficaz Moderada \\
\hline N05 & 03 & Adaptação Ineficaz Moderada \\
\hline
\end{tabular}

Tabela 4 - Eficácia Adaptativa em pacientes diabéticos com mau controle glicêmico -

Grupo II

\begin{tabular}{|c|c|l|}
\hline Sujeito & Total de Pontos & \multicolumn{1}{|c|}{ Classificação Diagnóstica } \\
\hline N12 & 1.5 & Adaptação Ineficaz Grave \\
\hline N10 & 1.5 & Adaptação Ineficaz Grave \\
\hline N24 & 1.5 & Adaptação Ineficaz Grave \\
\hline N23 & 1.5 & Adaptação Ineficaz Grave \\
\hline N14 & 1.5 & Adaptação Ineficaz Grave \\
\hline N06 & 1.5 & Adaptação Ineficaz Grave \\
\hline N11 & 02 & Adaptação Ineficaz Severa \\
\hline N01 & 02 & Adaptação Ineficaz Severa \\
\hline N22 & 02 & Adaptação Ineficaz Severa \\
\hline N18 & 02 & Adaptação Ineficaz Severa \\
\hline N08 & 02 & Adaptação Ineficaz Severa \\
\hline N04 & 02 & Adaptação Ineficaz Severa \\
\hline N02 & 2.5 & Adaptação Ineficaz Severa \\
\hline N03 & 03 & Adaptação Ineficaz Moderada \\
\hline N25 & 03 & Adaptação Ineficaz Moderada \\
\hline
\end{tabular}




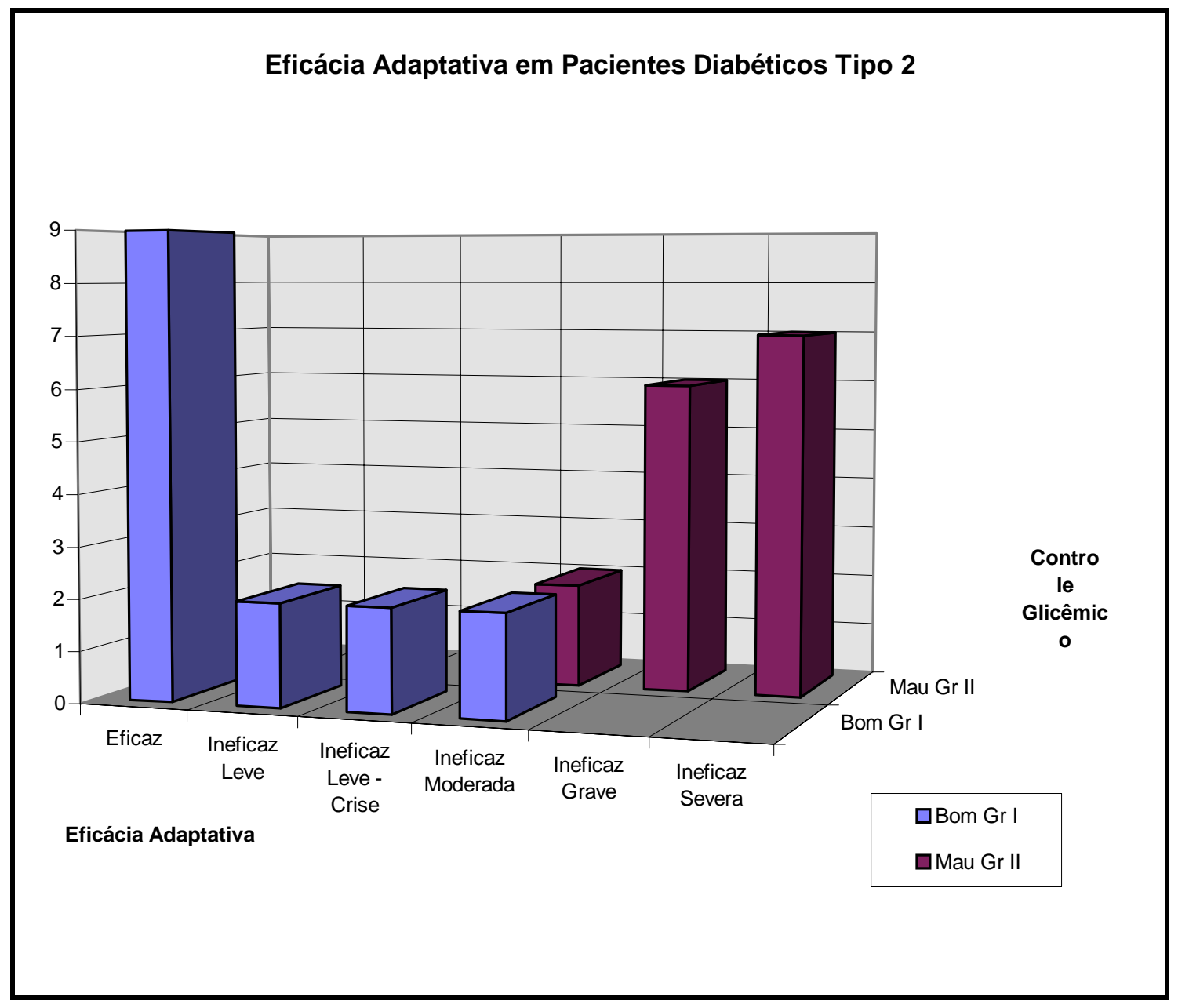

Figura 3

\section{A.2 - Análise comparativa do equilíbrio interno do ego em pacientes diabéticos tipo} 2, divididos em Gr I, de bom controle, e Gr II, de mau controle glicêmico.

Analisando o Sistema Tensional Inconsciente Dominante (STDI) dos grupos I e II, através de parâmetros estatísticos, observamos que existe forte correlação entre a qualidade do controle glicêmico e o equilíbrio interno do ego. Assim, quando as relações de objeto tendem à adaptação ou são positivas, melhor o controle glicêmico. 
Tabela 5 - Equilíbrio adaptativo do ego em pacientes diabéticos com bom controle glicêmico - Gr I

\begin{tabular}{|c|c|c|}
\hline Sujeito & Total de pontos & Graduação do Equilíbrio Adaptativo \\
\hline N16 & 51 & Relações Positivas \\
\hline N13 & 47 & Relações Positivas \\
\hline N30 & 53 & Relações Positivas \\
\hline N29 & 47 & Relações Positivas \\
\hline N26 & 52 & Relações Positivas \\
\hline N27 & 50 & Relações Positivas \\
\hline N15 & 52 & Relações Positivas \\
\hline N20 & 54 & Relações Positivas \\
\hline N28 & 41 & Tendência Adaptativa \\
\hline N17 & 46 & Tendência Adaptativa \\
\hline N21 & 39 & Tendência Adaptativa \\
\hline N07 & 39 & Tendência Adaptativa \\
\hline N05 & 40 & Tendência Adaptativa \\
\hline N09 & 45 & Tendência Adaptativa \\
\hline N19 & 43 & Tendência Adaptativa \\
\hline
\end{tabular}


Tabela 6 - Equilíbrio Adaptativo do Ego em Pacientes Diabéticos com Mau Controle Glicêmico - Gr II

\begin{tabular}{|c|c|c|}
\hline Sujeito & Total de pontos & Graduação do Equilíbrio Adaptativo \\
\hline N10 & 14 & Relações Muito Negativas \\
\hline N24 & 17 & Relações Muito Negativas \\
\hline N11 & 19 & Relações Muito Negativas \\
\hline N14 & 17 & Relações Muito Negativas \\
\hline N03 & 15 & Relações Muito Negativas \\
\hline N02 & 13 & Relações Muito Negativas \\
\hline N18 & 16 & Relações Muito Negativas \\
\hline N08 & 18 & Relações Muito Negativas \\
\hline N22 & 20 & Relações Negativas \\
\hline $\mathbf{N 2 3}$ & 22 & Relações Negativas \\
\hline N25 & 22 & Relações Negativas \\
\hline N01 & 24 & Relações Negativas \\
\hline N12 & 20 & Relações Negativas \\
\hline N04 & 29 & Relações Negativas \\
\hline
\end{tabular}




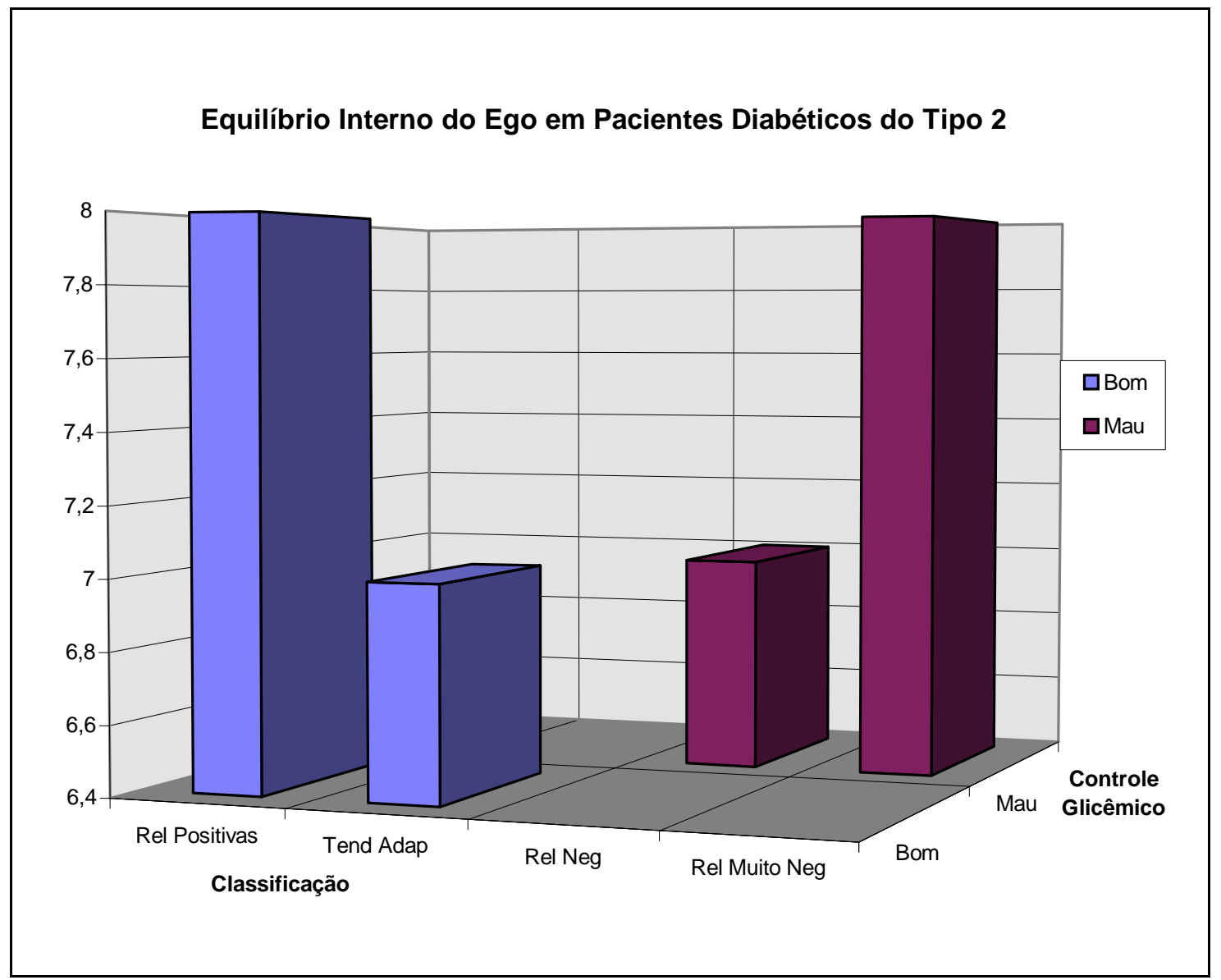

Figura 4

\section{A.3.- Análise Comparativa de Frequência das Posições Depressiva, Esquizoparanóide e Viscocárica em Pacientes diabéticos do Tipo 2, divididos em Gr I de Bom Controle e Gr II de Mau Controle.}

As 360 histórias contadas por 30 pacientes diabéticos na apresentação das pranchas do TRO foram analisadas através do Sistema Tensional Inconsciente Dominante. A partir deste estudo foram determinadas as posições. 
No Grupo I predominou a posição depressiva, que aparecia em 75\% das histórias. A posição esquizoparanóide ocorreu em 25\%. No Grupo II, diferentemente, o predomínio foi da posição esquizoparanóide, presentes em $60 \%$ das histórias, enquanto a posição depressiva aparece em 30\% das histórias.

Quanto à posição viscocárica sua incidência, na amostra de pacientes diabéticos do tipo 2 é muito pequena, aparecendo em 10\% das histórias.

Tabela 7 - As Posições Depressiva, Esquizoparanóide e Viscocárica em 30 pacientes diabéticos do tipo 2, divididos em Grupo I e Grupo II

\begin{tabular}{|l|c|c|}
\hline \multicolumn{1}{|c|}{$\begin{array}{c}\text { Posições } \\
\text { (STID) }\end{array}$} & $\begin{array}{c}\text { Pacientes Diabéticos de } \\
\text { Bom Controle } \\
\text { Gr I }\end{array}$ & $\begin{array}{c}\text { Pacientes Diabéticos de } \\
\text { Mau Controle } \\
\text { Gr II }\end{array}$ \\
\hline Depressiva & 134 & 55 \\
\hline Esquizoparanóide & 46 & 105 \\
\hline Viscocárica & 0 & 20 \\
\hline
\end{tabular}

A análise através de parâmetros estatísticos demonstrou que existe forte correlação entre as posições e a qualidade do controle glicêmico. Assim, os pacientes com bom controle glicêmico apresentam constelação típica da posição depressiva, enquanto que os com mau controle glicêmico tendem para relações de objetos típicas da posição esquizoparanóide. 


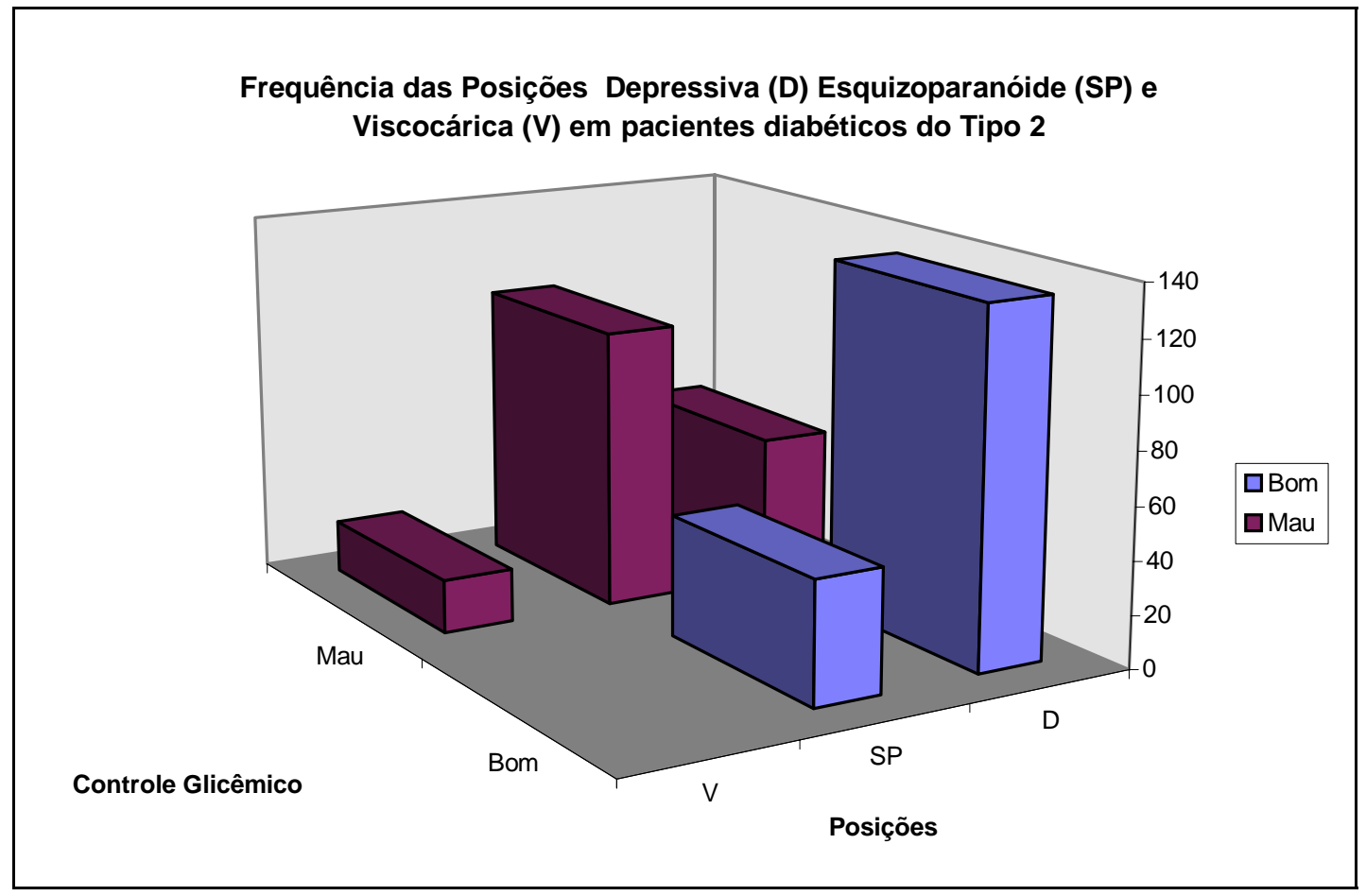

Figura 5

\section{A.4 - Medindo a presença das Organizações Patológicas através de micro-fatores extraídos da análise da EDAO.}

A presença das organizações patológicas foi medida através da Entrevista Clínica - EDAO, segundo o tipo de resposta que os pacientes apresentaram. A análise destas respostas mostrou, em grupos distintos, a presença sistemática de micro-fatores que, atuando cumulativamente ora geravam a possibilidade de melhora da adaptação e ora geravam uma rigidez própria das organizações patológicas, que impediam a melhora do paciente. 
Na análise das respostas dos pacientes do Gr I, nos quais o controle glicêmico era bom, não se observou a presença das organizações patológicas. Estes pacientes apresentaram respostas que, cumulativamente, geravam a melhora da eficácia adaptativa.

Quadro IV - Relação de Micro-fatores presentes na análise da Entrevista Clínica EDAO, de pacientes diabéticos Gr I

$\Rightarrow$ Suporta a perda.

$\Rightarrow$ Aceita a dependência.

$\Rightarrow$ Elabora o luto.

$\Rightarrow$ Há bons objetos internos firmemente estabelecidos.

$\Rightarrow$ As relações de objeto são permeadas pela esperança.

$\Rightarrow$ Capacidade para suportar a frustração.

$\Rightarrow$ Utiliza a agressividade de forma construtiva.

$\Rightarrow$ Reconhece os limites e abdica dos sentimentos de onipotência.

$\Rightarrow$ Capacidade para estabelecer vínculos positivos.

$\Rightarrow$ Capacidade para utilizar seus recursos produtivos.

A partir da análise das respostas dos pacientes do Gr II, com mau controle glicêmico, foram observadas a presença e a intensidade da ação das organizações 
patológicas, que impediam qualquer forma de tratamento ou melhora na qualidade de vida.

Quadro V - Relação de Micro-fatores presentes na análise da Entrevista Clínica EDAO, de pacientes diabéticos Gr II.

$\Rightarrow$ Não é capaz de aceitar a perda do corpo saudável.

$\Rightarrow$ Não suporta a dependência.

$\Rightarrow$ Dificuldade para discriminar a qualidade dos objetos.

$\Rightarrow$ Os vínculos estabelecidos são permeados pela persecutoriedade.

$\Rightarrow$ Os objetos são sentidos como cruéis e perversos.

$\Rightarrow$ Apresenta sentimentos de onipotência e arrogância.

$\Rightarrow$ Não é capaz de utilizar a capacidade produtiva.

$\Rightarrow$ Incapacidade para utilizar a agressividade de forma construtiva.

$\Rightarrow$ Ganhos secundários da doença. 


\section{A.5 - Medindo a presença das Organizações Patológicas através da análise das defesas no Sistema Tensional Inconsciente Dominante - TRO.}

A avaliação do Sistema Tensional Inconsciente Dominante de 30 pacientes diabéticos do tipo 2 permitiu a compreensão da dinâmica do mundo interno e a natureza dos relacionamentos objetais inconscientes, através dos quais podes-se identificar, a presença ou nas das organizações patológicas, considerando os tipos de defesa utilizados.

A análise das defesas apresentadas pelos pacientes do Gr I revelou o predomínio da identificação projetiva normal, da repressão, da sublimação e da idealização. Os pacientes apresentavam liberdade para fantasiar e criar histórias. As defesas eram flexíveis, gerando a possibilidade de adaptação às situações. Não foi observada a presença das organizações patológicas.

Nos pacientes do Gr II as defesas apresentadas eram a identificação projetiva patológica, maciça e adesiva. A principal delas foi a paralisação, que apareceu com maior frequência. Este "recurso" impedia os pacientes de entrarem em contato com o material mobilizado pela prancha e, consequentemente, com seu mundo interno e seus sentimentos. Isso gerou a imobilização ou paralisação frente às situações propostas pelas pranchas do TRO, fenômeno característico das organizações patológicas.

Assim, foi possível observar a presença e a ação das organizações patológicas nos pacientes diabéticos com mau controle glicêmico(Gr II).

\section{B. Análise qualitativa dos resultados apresentados por trinta pacientes diabéticos do} tipo 2, divididos em Grupo I, de bom controle, e Grupo II, de mau controle. 
O objetivo deste trabalho foi analisar, numa amostra de 30 pacientes diabéticos do tipo 2, divididos em Gr I, de bom controle glicêmico, e Gr II, de mau controle, se havia alguma relação entre a qualidade do controle e a presença das organizações patológicas.

A dificuldade foi encontrar instrumentos que pudessem medir a presença das organizações patológicas. Ao descrever esses sistemas defensivos, Steiner (1997) nos chama a atenção para dois pontos. O primeiro é sobre os traumas e privações sofridos pelo indivíduo e que têm influência decisiva na gênese dessas organizações. O segundo, sobre a necessidade de compreender as configurações das posições depressiva e esquizoparanóide e do interjogo entre elas. Acrescentamos neste trabalho a posição viscocárica.

Quanto ao primeiro ponto consideramos que além do surgimento dessas organizações, em princípio como defesa, temos que considerar, em muitos casos, sua supremacia e persistência ao longo do tempo transformando-se num modo de funcionamento psíquico. Não se trata da ação dessas organizações nos episódios de crise, mas de situações que se repetem e perpetuam na vida da pessoa. Sendo assim optamos pela utilização da Entrevista Clínica Preventiva. Com os dados coletados fizemos a análise através da Escala Diagnóstica Adaptativa Operacionalizada - EDAO.

Quanto ao segundo ponto proposto por Steiner (1997), da importância da compreensão das posições e o interjogo entre e no interior delas, buscamos obter este esclarecimento através do Teste das Relações Objetais de Phillipson (TRO).

\section{B.1 Análise através da Escala Diagnóstica Adaptativa Operacionalizada - EDAO}

Utilizando o modelo proposto por Simon (1989), através da Entrevista Clínica, tivemos a possibilidade de ter uma visão ampla do funcionamento psíquico de cada um dos pacientes diabéticos. A EDAO tem como objetivo identificar a eficácia adaptativa, através da classificação do indivíduo a partir da adequação das respostas que ele 
apresenta para solucionar as necessidades provocadas por estímulos provenientes do mundo interno e externo. Assinalamos a palavra solucionar pois através do tipo de solução dada pelo sujeito, conseguimos encontrar as evidências da presença das organizações patológicas.

Os pacientes do Grupo I deram respostas predominantemente do tipo pouquíssimo adequadas e tiveram como classificação diagnostica a Adaptação Ineficaz Grave e Severa. Esse tipo de resposta apesar de solucionar o problema do indivíduo não lhe traz prazer e gera conflitos internos ou externos. "Esse conjunto de tendências a soluções pouco ou pouquíssimo adequadas, acompanhadas de objetos internos persecutórios ou idealizados, formam “organizações patológicas” (Steiner, 1987) que adquirem autonomia e independência quanto às intervenções diretas do ambiente.” (Simon, 2000, p. 5).

Por outro lado analisando as respostas dos pacientes do Gr I, não se detecta a presença destas organizações. São pacientes com respostas, predominantemente, adequadas. Estas acompanhadas da presença de bons objetos internos, firmemente estabelecidos, permitem que o sujeito supere as situações de crises não comprometendo a eficácia adaptativa.

Analisando as respostas dos pacientes diabéticos, tanto de mau como de bom controle, podemos perceber a ação ou não das organizações patológicas. Procuraremos neste trabalho, a partir do material clínico, mostrar esta relação.

No setor orgânico dos 15 pacientes do Gr II observamos que a maioria não acredita na perda do corpo saudável. Eles não aceitam a idéia de que são diabéticos. Uma paciente, diabética há 6 anos, relatou que cuidou de sua mãe e irmã que morreram em função das complicações crônicas do diabetes. Apesar de ter sido informada de que poderia ficar diabética e de temer a doença e suas consequências, ela só soube que estava diabética após sofrer um infarto. Os conhecimentos sobre a doença e o fato de ter parentes que morreram por complicações crônicas do diabetes não teve nenhum efeito sobre esta paciente. 
Outro paciente, da mesma forma, conta que tanto seu pai como avô morreram de diabetes e suas complicações, mas ele só procurou o médico após descobrir uma úlcera no pé. Ao ser questionado sobre o fato de ele ter parentes diabéticos e saber que poderia também desenvolver a doença, ele disse que "apesar de saber que esta é uma doença de família nunca pensei que isto pudesse me acontecer”.(sic)

Nestes dois casos observamos a ação das organizações patológicas. Esta ação que tem repercussão no setor orgânico tem origem no setor afetivo-relacional. Estes pacientes foram levados a acreditar que nunca ficariam diabéticos. As organizações patológicas funcionam como um refúgio no qual nenhum sofrimento precisa ser experimentado. De forma onipotente e idealizada esses pacientes pensavam que nada poderia lhes acontecer.

As respostas dos pacientes do Gr I, de bom controle, são diferentes. Os pacientes são capazes de suportar a idéia de que eles podem ficar doentes. A vantagem é que o diagnóstico é feito, geralmente, antes que haja uma complicação. É o caso de uma paciente que, além de perder o marido, perdeu também o trabalho. O casal tinha um comércio e ela não pôde prosseguir sozinha. Após a morte do marido, e sem atividade, começou a engordar e ganhou rapidamente alguns quilos. Não se sentia bem e, por isso, resolveu procurar ajuda médica. Descobriu que estava diabética e ficou muito assustada. A partir do momento que foi ao médico, interessou-se por obter conhecimentos sobre sua disfunção. Mudou sua rotina de vida e, após 6 anos de diabetes, não apresenta nenhuma complicação.

Novamente observamos a influência do setor afetivo-relacional confirmando a idéia de Simon (1989) quando ele redefine a EDAO e mostra que este setor ocupa uma posição privilegiada na adaptação humana. No caso da paciente acima descrita, a morte do marido, fator externo negativo, gerou uma situação de crise que parece ter influído no desencadeamento do diabetes. Mas, em vez de a paciente sucumbir, ela foi capaz de, 
através de respostas adequadas, superar a crise e recuperar seu nível anterior de adequação.

Outra paciente, diabética há 6 anos e com bom controle, conta que descobriu o diabetes numa consulta de rotina. Na ocasião ficou muito preocupada por não conhecer nada sobre a doença. Ela conta que o médico a deixou muito tranquila e sugeriu que ela participasse de grupos de orientação. Os bons objetos internos, firmemente estabelecidos, permitiram que as relações estabelecidas fossem permeadas pela esperança e confiança. Nesta mesma época, participou de um programa para diabéticos e aprendeu muitas coisas. Ela disse que enfrentou muitas dificuldades, pois as pessoas falavam muitas coisas ruins sobre diabetes. Diziam que ela poderia ficar cega, com problemas no coração, enquanto outras diziam que, apesar de não ter cura, o tratamento era possível. Assim, apesar de saber que tratava-se de uma doença incurável, passou a acreditar que poderia viver bem e por mais tempo se fizesse o tratamento de forma adequada.

Esta mesma paciente conta que aprendeu muitas coisas com a nutricionista no grupo de orientação e percebeu que a alimentação em sua casa era inadequada. Ela disse "em minha casa a gente comia muita gordura, muita fritura, muitos doces. Resolvi mudar a alimentação e todos reclamaram muito, mas todos emagreceram e no fim me agradeceram.”(sic)

Analisando as respostas do setor sócio-cultural pode-se observar as dificuldades dos pacientes do Gr II. As respostas apresentadas pelos pacientes eram, geralmente, pouquíssimo adequadas e mostraram que eles não cultivavam a vida social. Este é outro indício da presença das organizações patológicas. Elas “ajudam” o paciente a fugir da ansiedade mas, em contrapartida, os levam à perda de contato com as pessoas e com a realidade.

Pôde-se observar neste setor que as festas e atividades sociais eram evitadas, aparentemente pela ação de partes destrutivas e onipotentes, que não suportavam a idéia de limites e dependência, e impediam as relações com objetos bons que trouxessem 
qualquer tipo de prazer. Uma paciente dizia que "sempre reunia os amigos em minha casa, comia e bebia à vontade mas agora não posso mais fazer isso, que graça tem eu ver todo mundo comendo e bebendo e eu não poder fazer nada disso.”(sic) Outro dizia que não saía mais de casa pois temia voltar a fumar, beber e comer coisas que lhe fizessem mal.

Parece que havia uma dificuldade para discriminar a qualidade dos objetos. Assim, eles tinham a idéia de que por precisarem ter uma dieta adequada, não poderiam ter qualquer tipo de prazer nos passeios ou encontros com amigos. Esta é mais uma manobra das organizações patológicas. Na realidade, em nenhum momento esses pacientes eram capazes de fazerem uma dieta adequada. Sendo assim, fica claro que este não seria o motivo para evitar os encontros sociais.

Em alguns casos, ainda no setor sócio-cultural, outro aspecto foi observado. Havia um tipo de relação que, em princípio, poderia ser considerada saudável, mas que era permeada pela crueldade. Uma paciente disse que não tinha vontade de ir para nenhum lugar mas que frequentava a igreja com regularidade. Ela completa dizendo que "sou muito católica e Deus quis que a minha vida ficasse assim"(sic).Outro paciente disse que é evangélico, tem muita fé e acrescenta que "nada podemos fazer contra os desígnios de Deus”(sic). Este tipo de atitude parece mais ligada a um tipo de culpa persecutória e não à aceitação da situação.

Quanto aos pacientes do Gr I, no setor sócio-cultural observou-se outra situação. De uma forma geral eles apreciavam a vida social, tinham amigos e frequentavam as instituições. Uma paciente de 55 anos, diabética há 6 anos, conta que é muito “passeadeira” e que saía todas os dias pela manhã para caminhar com duas amigas, lembrando que "além de ser bom para a saúde a gente se diverte muito."(sic) Esta paciente foi capaz de transformar fatores referentes ao tratamento, geralmente considerados negativos em positivos, considerando-os como atividades sociais. 
Outra paciente de 57 anos, diabética há 7, mostrou que as dificuldades financeiras não impediam que ela participasse de atividades sociais, aproveitando eventos gratuitos promovidos, geralmente, por órgãos públicos. Assim, ela frequentava, sem custo, cinema, teatro e eventos musicais, atividades que lhe davam muito prazer.

Observou-se também no caso de um paciente de 58 anos, diabético há 11 anos que, apesar de estar vivendo uma situação de crise pela perda de dois familiares, não abdicou de sua vida social. Ele dizia que não tinha desejo de sair de casa, mas esforçavase para sair. Ele tinha alguns amigos com os quais sempre se reunia para jogar malha. Ele disse que "não tinha vontade de sair de casa, mas quando saía e encontrava meus amigos ficava muito melhor”.(sic) Parece, neste caso, que os objetos bons firmemente estabelecidos ajudam a pessoa a tomar atitudes que lhe favoreça, melhorando seu nível de adequação. A pessoa é capaz de experimentar, graças às respostas adequadas, sentimentos de felicidade.

A análise do setor produtividade mostrou que os pacientes do Gr II, de mau controle, tiveram perdas importantes. O fato de serem diabéticas, de não conseguirem manter um bom controle glicêmico e por conseguinte terem sintomas agudos e crônicos gerava respostas que levavam à ineficácia adaptativa.

Havia insatisfação por vários motivos. Alguns queixavam-se por não terem prazer em suas atividades. Outros, por sentirem-se impossibilitados de fazer o que realmente gostavam, ou por terem a fantasia de que por estarem doentes estavam incapazes para o trabalho. Apesar de alguns obterem ganhos secundários pelo fato de estarem diabéticos, geralmente a dependência gerava angústia ainda maior. Também havia aqueles que, de fato, por complicações crônicas, estavam impedidos de trabalhar.

Uma paciente revela com tristeza, que precisou abandonar o trabalho após um infarto. Era empregada doméstica há 30 anos. Quando ficou doente, trabalhava para a mesma família, há 10 anos, inclusive morando com eles. Entendia que não podia ficar na casa e que eles precisavam de outra funcionária. "Eu era uma empregada e não pessoa 
da família e abandonar o trabalho foi a pior coisa que poderia me acontecer, de todas que já aconteceram. ”(sic)

Outra paciente parecia obter ganhos secundários pelo fato de ser diabética. Ela dizia ser inútil para o trabalho e que não podia fazer esforço "eu sei que as atividade da casa pioram meu estado de saúde.”(sic) Este tipo de resposta reduz a eficácia adaptativa e gera sentimentos ruins de incapacidade frente à vida.

A análise das respostas dos pacientes do Gr I, no setor produtividade, revelou que eles, geralmente, têm uma atividade produtiva. Esta lhes traz, além da gratificação financeira, prazer. Uma paciente de 53 anos, há 4 diabética, conta que depois de ver os filhos crescidos e sendo analfabeta aprendeu a ler e escrever, em um curso gratuito para alfabetização de adultos. Ela sentia-se muito bem e ficou animada para trabalhar fora de casa. Procurou trabalho em vários lugares e conseguiu, depois de 2 anos, como inspetora de alunos em uma escola, onde já conhecia várias pessoas. Gostava da diretora e dos professores. Todos a tratavam bem e ela está muito satisfeita, "mas o melhor é o salário isto é uma novidade na minha vida”.(sic)

Após a análise das respostas dadas aos setores orgânico, produtividade e sóciocultural, resta o setor Afetivo-Relacional. Apesar de ele já ter sido citado várias vezes faremos uma análise mais pormenorizada considerando, principalmente, sua importância.

Um dos pacientes do Gr II, do sexo masculino, com 47 anos, casado, com duas filhas, havia estudado até a $5^{\mathrm{a}}$.série do $1^{\mathrm{o}}$.grau e possuía bons conhecimentos sobre o diabetes. Sua atividade profissional era um pequeno comércio mas, no momento, não trabalhava. Ele conta que antes de ficar diabético era um homem da farra, chegava sempre tarde em casa e tinha muitos conflitos familiares. Não era capaz de abdicar do prazer imediato. Após o diagnóstico, sua vida modificou-se. Hoje ele não trabalha, sua vida é regrada e passou a pensar na família. Ele afirma que agora está melhor e que se transformou em outra pessoa, melhor do que era antes. Esta parece ser uma experiência emocional corretiva. Podemos dizer que é uma resposta adequada. O paciente se sente 
bem e não existem conflitos internos ou externos. Mas, seguindo o discurso do paciente, percebemos a ação silenciosa da organização patológica. Ele tornou-se completamente dependente da família e, através da mobilização da culpa em seus familiares, obteve ganhos secundários por ser diabético. Ele diz “ mas está melhor assim porque em casa as filhas e a mulher ficam cheias de cuidados comigo, elas me agradam muito e não deixam faltar o remédio e a alimentação.”(sic)

Ele não trabalha e não sai de casa. Antes era um homem da farra agora é um bom homem e isso parece garantir sua salvação. Ele diz ” vou ficar curado e vou voltar à minha vida normal"(sic). As partes destrutivas e onipotentes de forma idealizada fazem o paciente acreditar que, a qualquer momento, tudo voltará a ser como era antes. Ele não terá mais diabetes e poderá voltar para a farra.

Outro aspecto que chama a atenção é o fato de que todo o conhecimento que o paciente tem sobre diabetes, principalmente, por ser uma doença crônica em que o controle é importante para evitar complicações, não faz qualquer efeito na mente do paciente. Ele está impedido pela organização de obter qualquer compreensão emocional ou cognitiva verdadeira. Ele crê que o contato com a realidade é insuportável e que portanto está evitando a morte. Como a qualidade das relações com os objetos não pode ser discriminada, os profissionais da saúde podem transformar-se em objetos persecutórios.

Este tipo de proteção perversa oferecida pela organização patológica, este refúgio onde o paciente não precisa lidar com a angústia da perda do corpo saudável gera uma situação aparentemente muito confortável, mas que não permite o contato com as pessoas e com a realidade. Na verdade a pessoa vive de forma alienada, sem nenhuma possibilidade de mudança.

Outro caso era o de uma paciente de 58 anos, do sexo feminino, casada, com dois filhos. Ela havia completado o $2^{\circ}$. grau e tinha bons conhecimentos sobre o diabetes. Não tinha nenhuma atividade profissional, era diabética há 9 anos e observamos a ação das organizações patológicas, após o diagnóstico. A paciente se coloca em uma posição de 
onipotência e arrogância e pensa que as pessoas têm obrigação de cuidar dela. Sua enteada tinha um pequeno comércio onde ela pegava, regularmente, alimentos. Mas a enteada resolveu conversar com ela a respeito desta situação e disse que ela não tinha condições de continuar vendendo sem receber. A paciente ficou muito irritada, e como não era capaz de demonstrar qualquer tipo de gratidão pelo fato de muitas vezes a enteada

não ter cobrado pelas suas compras, diz "ela foi muito injusta comigo, me ofendeu dizendo que eu não pagava minhas contas, ela sabe que eu sou diabética.”(sic)

A análise das respostas de uma paciente de 51 anos, diabética há 10 anos, ilustra bem os efeitos na adaptação, quando as respostas pouquíssimo adequadas estão encadeadas umas às outras. Esta paciente apresentava um quadro de obesidade, estava 30 kg. acima de seu peso ideal. Ela conta que sempre foi magra, mas que em sua primeira gravidez, quando ocorreu o primeiro episódio de hiperglicemia, engordou 20 kg. Depois de dois anos, e não tendo voltado ao seu peso anterior, engravidou novamente e ganhou mais peso. Hoje diabética, não consegue manter um bom controle, afastou-se do marido, não se sente à vontade, tem vergonha do seu corpo e teme ser rejeitada por ele. Ela chorou durante a entrevista e disse que não tem mais prazer na vida, sente ódio por não conseguir mudar e que, aos poucos, foi deixando de fazer tudo de que gostava. Nos últimos 15 anos, todas as suas tentativas para modificar este quadro foram em vão. Fez tratamentos para emagrecer e frequentou academias. Parecia não ter motivos para viver, sentia-se abandonada, frustrada e com raiva. Alimentava sentimentos de fracasso e impotência diante da vida. Nesse relato notamos que a paciente experimenta um tipo de angústia paranóide, que a leva para um estado de paralisação e leva a acreditar que não existe nenhuma saída, como se sua vida estivesse perdida. Esta paciente revela a existência de uma fantasia inconsciente, como a descrita por Meltzer (1991), que dos objetos mortos, extremamente persecutórios, não se pode fugir com sucesso.

Neste caso, também observamos como certas partes destrutivas estão disfarçadas, silenciosas e excindidas do self fazendo com que sua ação seja quase imperceptível. Em princípio, a paciente gera no entrevistador um sentimento de paralisação. Sua tristeza é 
contagiante e a sensação é de que realmente nada pode ser feito e, inclusive, perguntado. Ela disse com voz trêmula e os olhos cheios de lágrimas "sei que preciso emagrecer, já fiz de tudo, mas não consigo”.(sic) Após o impacto provocado pelo material, o entrevistador investigou um pouco mais as tentativas de melhora da paciente ou suas respostas supostamente adequadas. Dos tratamentos médicos para a obesidade, fica evidente a falta de paciência e a impossibilidade de suportar a frustração. Ela espera sempre um efeito instantâneo e que precisa emagrecer rapidamente. Outro aspecto é o da persecutoriedade dos objetos. Os remédios sempre têm efeitos colaterais insuportáveis e causam a sensação de estarem piorando seu estado de saúde. Deixando de tomar o remédio e não conseguindo manter a dieta, o médico também transforma-se em perseguidor e é abandonado. Emerge o ódio e a culpa pelo fracasso associado ao sentimento de impotência . Estes sentimentos servem de combustível para movimentar e dar forças à organização patológica.

Das tentativas de emagrecimento através de exercício físico constatou-se o mesmo quadro. A paciente disse que por insistência do marido, entrou em uma academia. Sentia muito cansaço e mais ainda vergonha. Ela estava com $30 \mathrm{~kg}$ acima do peso ideal e as pessoas que frequentavam a academia eram todas magras e bonitas. Ela diz "pensei que o meu marido queria o meu bem mas vi que ele queria era me envergonhar por causa da minha gordura.”(sic) Mais uma vez observa-se a dificuldade destes pacientes para discriminarem a qualidade dos objetos.

Analisando as respostas dos pacientes diabéticos do tipo 2, com bom controle glicêmico, observou-se no setor afetivo-relacional que a presença de fatores negativos geravam crises, mas que estas eram superadas, elaboradas. As perdas geravam sofrimento mas a pessoa suportava a realidade e, após certo período, era capaz de fazer novos vínculos permeados pela confiança e pelo amor. A libido, antes investida no objeto perdido, pôde ser destinada a um outro objeto.

Uma paciente de 55 anos, diabética há 6 anos, conta que viveu um período difícil após a perda do marido. A superação, segundo ela, veio pelo fato de ela ter familiares 
com os quais tem bons vínculos e com quem pode contar integralmente, deixando claro que possuía vida própria, mas não temia a dependência. Entre outras coisas, lembrou com alegria do presente que ganhou do irmão. Ela foi convidada para uma festa e ele se prontificou a dar-lhe o vestido. Contou que ele tem boa situação financeira e que sempre a ajuda. Ela diz "ele sabe que eu vivo da pensão do meu marido e sou muito agradecida a ele por não me deixar faltar nada."(sic)

Outro paciente de 58 anos, diabético há 11 anos, iniciou a entrevista contando sobre perdas significativas, como de sua esposa há 1 ano e de seu filho adolescente, que morreu de Aids três meses depois. Quando sua esposa faleceu, seu filho, que era viciado em drogas, estava internado. Ele o visitava regularmente e não falou sobre a morte da mãe. Contou que sofreu muito com este filho, mas que o rapaz sofria mais ainda e como ele estava morrendo, preferiu não falar nada. Ele disse que se sentia muito só e triste e que, às vezes, era difícil acreditar em tudo o que havia acontecido. "Eu sei que eles morreram e que eu tenho meus outros filhos e amigos, mas os dois moravam comigo e de repente eu fiquei sozinho na casa."(sic) Reconhece que hoje está melhor e que é bom ter com quem falar. Muitas vezes pensou que fosse culpado, que poderia ter evitado a morte deles, principalmente do filho e que sentia culpa por não ter percebido o vício dele. Hoje não pensa mais assim. Sabe que o fato já ocorreu e nada do que pensar pode modificar o passado.

No relato deste paciente percebemos que ele mantém contato com seu mundo interno, tem capacidade para suportar o sofrimento e aceitá-lo. As relações estabelecidas são permeadas por impulsos libidinais. Ele é capaz de ser generoso e compreender o sofrimento do outro.

Comparando as respostas dos dois grupos de pacientes diabéticos do tipo 2, de bom e mau controle, fica evidente a diferença apresentada entre eles.

No Gr II, a classificação diagnóstica é, em 13 dos casos avaliados, de Adaptação Ineficaz Grave ou Severa. Apenas dois casos de Adaptação Ineficaz Moderada. O que 
determinou esta avaliação foi o setor Produtividade. Citamos o exemplo de uma paciente de 52 anos, casada, que iniciou uma atividade com a qual tinha muito prazer e ajudava nas despesas da casa. Ela conta que sempre gostou de cozinhar e todos gostavam muito do

que ela produzia. Assim, resolveu fazer salgados para vender. Seu marido concordou em ajudá-la e o negócio estava indo muito bem. Ela disse "Além de fazer uma coisa que eu gosto posso ainda ajudar nas despesas da casa.”(sic)

No Gr I, de bom controle, nenhum dos pacientes apresentou classificação diagnóstica Ineficaz Severa ou Grave. Neste grupo, as respostas tendem a trazer soluções que mantêm o nível de adequação. São respostas adequadas ou em alguns casos pouco adequadas.

\section{C - Análise através do Teste das Relações Objetais de Phillipson - TRO}

A análise da dinâmica do mundo interno, através do Sistema Tensional Inconsciente Dominante, nos permitiu identificar as posições e compreender melhor a ação das organizações patológicas.

\section{C.1 - Análise comparativa na Série A}

A análise das histórias produzidas pelos 15 pacientes diabéticos do tipo 2, com mau controle glicêmico, revelou a dinâmica interna deles. Na série A as pranchas apresentam pouca estruturação permitindo a livre imaginação do paciente. É esperado, nesta série, o predomínio da ansiedade depressiva e das defesas de controle obsessivo. 
Os pacientes do Gr II, de mau controle, apresentaram na série A, histórias nas quais observou-se o predomínio da posição esquizoparanóide (= ansiedade persecutória). As defesas predominantes foram as de controle onipotente. Podemos, através destes dados, perceber que estes pacientes não apresentavam um bom índice de adaptação.

Os resultados da análise das histórias dos pacientes do Gr I, por outro lado, revelaram uma situação bem diferente. Houve o predomínio da posição depressiva e das defesas de controle obsessivo, mostrando a melhor integração do ego e um bom índice de adaptação.

\section{C.1.1 - Análise da lâmina A1(1)}

A lâmina A1(1) por ser a primeira prancha apresentada ao paciente e por ter um personagem indica como o sujeito se adapta às novas situações quando tem a necessidade de enfrentá-las sozinho.

Um paciente do Gr II, de mau controle glicêmico, conta a seguinte história: "Parece que estou vendo um homem com os braços cruzados e a perna meio aberta. Tem uma cinta apertada na cintura. É o que eu vi. Não sei o que ele está sentindo (pausa) pelo jeito ele está olhando alguma coisa, está de pé e assustado. Ele olha algum movimento, tem outra pessoa, alguém fazendo um trabalho em frente a ele e ele está corrigindo a pessoa. Ele está fazendo alguma coisa e se for preciso ele corrige com a cinta.” O desenvolvimento desta história nos mostra que, em princípio, o ego é capaz de ter o contato com a situação de solidão, a angústia emerge e é predominantemente persecutória. Esta determina a criação de um novo personagem que em vez de trazer alívio, intensifica a angústia. O ego, como defesa, ataca o objeto. Os sentimentos experimentados são próprios da posição esquizoparanóide. 
Da mesma forma, outra paciente, na apresentação da lâmina A1(1) conta: “Tem um homem, está em uma névoa, tem uma outra silhueta e pela postura dele está tenso, com algum problema. O outro está sentado ou está dando uma bronca ou as pessoas estão discutindo e o clima está meio tenso. Pela postura o homem humilhou o que está abaixo. Este homem de pé parece autoritário, machão e em consequência a mulher é humilde, sem reação, ela está tão por baixo, eu não consigo fazer um desfecho (pausa). Quero achar a palavra, humilhação, dominação, mas é mais forte é muita repressão." Neste caso também a situação de solidão faz emergir angústia persecutória. Na tentativa de atenuá-la, o ego lança mão da alucinação positiva, criando um segundo personagem. Este, em vez de criar um continente acolhedor, intensifica a angústia, caracterizando a ação do objeto interno vingativo.

Estes dois exemplos parecem demonstrar a situação de paralisação interna e externa a que estão submetidos estes dois pacientes. Eles encontraram um refúgio e devem permanecer nele. Qualquer tentativa de movimento é acompanhada de retaliação. As organizações patológicas agem de forma a não permitir o crescimento e o estabelecimento de vínculos positivos. Em contrapartida oferecem uma suposta segurança baseada na idéia de que o sofrimento pode ser evitado.

Os pacientes do Gr I, de modo geral, mostram uma situação diferente. Uma das histórias contadas a partir da lâmina A1(1) era: "Eu acho que ele está em uma sala fechada, parece que tem uma planta e ele está com a mão no queixo e o braço cruzado, pensando. Ele está aqui sozinho para pensar. Ele é um empresário que precisa tomar decisões importantes. Ele precisa pensar, pois deseja tomar a melhor decisão.” O título dado é o "Pensador". Pode-se perceber através da análise desta história que as situações de solidão eram temidas, mas suportadas. A identificação projetiva é utilizada em um nível adequado e a repressão pôde ser utilizada.

A possibilidade da utilização da repressão como mecanismo de defesa adaptativa é muito importante pois demonstra a flexibilidade do ego. "A repressão como mecanismo adaptativo marca a possibilidade de clivagem entre a vida consciente e a vida 
inconsciente. Tal clivagem não se refere a uma divisão rígida e irreversível mas a uma membrana permeável, porosa, que, ainda que possibilite a separação de ambos os aspectos da realidade psíquica, permite ao ego conectar-se com fantasias ou recordações funcionalmente reprimidas (processo primário - processo secundário).” (Grassano, 1996, p.25).

Outra história contada por um paciente do Gr I, de bom controle, ilustra como a persecutoriedade pode ser controlada a partir da presença de bons objetos internalizados que permitem ao ego utilizar defesas no nível normal e adaptativo. "É um homem. É difícil saber o que está acontecendo (pausa). Ele olha para alguma coisa. Está de braços cruzados e pelo jeito alegre ele não está, ou pode estar perplexo. Ele está admirado, com a claridade (pausa). Ele ficou assustado, quis fugir (pausa), mas vai procurar saber o que é (pausa). Ele estava sozinho em um lugar estranho, ele ouviu um barulho e ficou assustado, foi atrás e viu que era outra pessoa chegando. Na companhia de outra pessoa as coisas ficam mais fáceis e ele tem agora uma companhia.” A angústia e a persecutoriedade do objeto estão presente mas o ego é capaz de suportar o caos e o medo do desconhecido. As pausas resultam em criatividade e abrem novas possibilidades, não é uma paralisação. O ego encontra um lugar onde suas angústias podem ser contidas.

\section{C.1.2 - Análise da Lâmina A2(2)}

Na lâmina A2(2) a presença do segundo personagem pode gerar alívio para aqueles cuja situação de solidão for muito angustiante. Em alguns casos de pacientes diabéticos de mau controle, a presença do segundo personagem é vista como algo perigoso e perverso.

A apercepção de um paciente do Gr II na lâmina A2(2) parece mostrar este fenômeno. "Duas mulheres, parece que uma está contente, aconselhando. A outra está mais séria. São amigas. A que está contente está com um sorriso. Se ela for consciente e os conselhos forem bons ela vai ouvir e pelo jeito são bons conselhos.” Até este momento da história parece que o vínculo é positivo e o par pode estabelecer uma relação 
comensal. Mas, na sequência, instala-se um clima de desconfiança, uma clara dificuldade para discriminar a qualidade dos objetos, predominando os impulsos destrutivos. “(pausa) ela está em dúvida se seguirá os conselhos, ela não sabe se é para o bem mesmo, ela está desconfiada que a outra quer prejudicá-la. Ela descobre que a outra quer prejudicá-la. Ela parece que é boa, mas não é.” O título dado a esta história é "O engano”. Neste caso, pôde-se observar a ação das organizações patológicas impedindo as relações libidinais, gerando confusão e caos na mente da paciente.

Outro paciente relata a seguinte história na prancha A2(2) "É um homem e uma mulher. Parece que estão tristes. Não estão conseguindo nada de bom. A situação está difícil. Eles estão em sérias dificuldades. Se lutassem poderiam melhorar. Por exemplo, se for ao médico pode melhorar da doença, é assim! (pausa) Nem sempre adianta, às vezes vai ao médico e nada resolve. A prova é que todas as histórias são muito tristes. Não adianta fazer nada, mas isto não tem importância.” A situação de par não era suficiente para aplacar a angústia. $\mathrm{O}$ ego tentava encontrar um objeto bom protetor, mas fracassou e predomina a indiferença. Neste caso, a ação das organizações patológicas parece gerar um estado no qual o sofrimento psíquico é negado, dando lugar à indiferença. Novamente para não sofrer, por não suportar a dor psíquica ,o ego recorre ao refúgio. Este aplaca a angústia mas impede qualquer relação positiva com os objetos.

Outro tipo de relação objetal observada no Gr II foi a de que o objeto ou o par era sentido como frágil. O objeto, em vez de cruel, era impotente. "Acho que são duas pessoas conversando, suponho que uma tenha um problema e não tenha muita força....." Na sequência da história observa-se a tentativa de encontrar um objeto bom, alguém suficientemente forte que pudesse ajudar nesta dificuldade. Ela disse “...e a outra tem bastante força, está animando.” Mas o predomínio dos impulsos destrutivos não permite a melhora. Prosseguindo a história “...mas parece que a pessoa não se animou muito. Não sei o que está acontecendo, não sei não, é só.” Completando o paciente diz o título da história: “A pessoa sem fé”.

De forma diferente as histórias contadas pelos pacientes do Gr I revelam, predominantemente, que o segundo personagem atenua a angústia e geralmente é sentido 
como bom. Um paciente conta a seguinte história na lâmina A2(2): “É um homem e uma mulher, parece que ele está querendo pegar a mão dela. Eles estão nus e ela parece muito tímida por causa da situação. (...........) ela se sente meio boba por hoje as coisas não serem assim, mas ela não está preparada. Ele vai compreender sabe que ela precisa de tempo e em uma próxima vez ela consegue superar. Ele vai ser capaz de esperar.” Pode-se observar que a sexualidade é sentida como algo perigoso e havia a necessidade de idealizar o par. A persecutoriedade provocada pela sexualidade é atenuada por um objeto idealizado, mas esta defesa, utilizada de forma adequada, permite a repressão e o equilíbrio do ego. As defesas são utilizadas de forma flexível, promovendo com os objetos bons a possibilidade de adaptação. As histórias são ricas, com começo meio e fim, abrindo-se para novas histórias.

\section{C.1.3 - Análise da Lâmina A3(8)}

A lâmina A3(8) evoca o conflito edipiano. O tema central é a separação e como o ego resolve esta questão. Na apresentação da lâmina A3(8), um paciente do Gr II conta a seguinte história: “É o mesmo casal que está olhando alguma coisa, tem outra pessoa junto. Não sei o que está acontecendo e não sei quem são essas pessoas, (pausa) Você é que tem que esclarecer quem são eles (pausa). Não sei o que está acontecendo e nem como termina essa história (pausa). Morreu todo mundo, é o além (pausa) e chega! ”

O contato com a realidade externa era precário. O mundo interno parece povoado por objetos ruins que levavam o ego ao estado confusional. A extrema angústia gera como defesa a identificação projetiva patológica provocando o afastamento da realidade. Empobrecido, o ego não é capaz de criar. A história é curta e o controle obsessivo (= é o mesmo casal) é uma defesa ineficaz. Em vez de tristeza, o ego experimenta, na transferência, sentimentos de raiva. A situação torna-se de tal forma insustentável que só resta, como defesa, a paralisação. 
Outro paciente conta a seguinte história, na lâmina A3(8): “ (Ele olha para a prancha faz uma pausa) É o fim da história, enterrou acabou (pausa)”. O aplicador pergunta de qual história isto é o fim. "Lembrei-me do enterro do meu pai. Eu senti muito a perda do meu pai. Chora (pausa). Minha família diz que não acredita que eu tenha sentido tanto, porque ele era vivo e não éramos próximos. Chega é só o que eu tenho para dizer. Ah! você deve querer um título para esta história, é o enterro.” A situação de exclusão não pôde ser suportada e a extrema angústia que emerge leva à identificação projetiva maciça. A impossibilidade de lidar com a separação, com a exclusão e os ataques ao par unido leva o ego ao aniquilamento.

Nesta mesma lâmina A3(8), um paciente conta que: “Aqui tem 3 vultos, 2 rapazes e um que está na frente dele. Só.” (afasta a prancha) A tentativa do psicólogo para obter, através do inquérito, outros dados é completamente inútil. As respostas do sujeito são “Não tenho idéia do que está acontecendo. Não ocorre nada. Não sei, os dois, talvez o que está sozinho não sei, não tenho idéia.” Parece, neste caso, que é impossível lidar com os sentimentos que emergem, o paciente não consegue manter uma distância saudável e paralisa.

Os pacientes deste grupo de mau controle, geralmente, não têm liberdade interna e não conseguem contar uma história. Eles perderam a capacidade imaginativa, criativa e isso pode ter ser determinado pela vicissitude do mundo interno protegido por uma organização patológica.

Uma história contada, a partir da lâmina A3(8), por um paciente do Gr I apresenta conteúdo bastante diferente. "Três pessoas. Três homens. Agora (pausa) onde estão andando? Parece que está um pouco escuro. Não estão juntas. Os dois juntos são amigos. O outro está só. Sente que está abandonado e sozinho. Os amigos vão conversando e vão se aproximando do que está sozinho (pausa). O que está sozinho cria coragem e vai conversar com eles.” A situação de exclusão frente ao par fazia emergir sentimentos de abandono. O ego fortalecido é capaz de suportar a ansiedade e controlar a persecutoriedade. Através da repressão consegue manter o equilíbrio dando um desfecho 
favorável para a história. Isso demonstra que o ego tem liberdade interna. A presença de objetos bons gera confiança para enfrentar o desconhecido.

\section{C.1.4 - Análise da Lâmina AG(5)}

Considerando que o paciente diabético experimenta a perda do corpo saudável, vivendo portanto concretamente uma situação de perda, a lâmina AG (5) merece uma atenção especial, pois ela nos permite a análise da situação de luto. Espera-se nesta lâmina o predomínio da ansiedade depressiva e sua elaboração através da capacidade do ego para suportar a dor, renunciar ao objeto e aceitar a situação imposta pela realidade. A presença da tristeza e da culpa é importante neste processo. Quando a situação não pode ser suportada, aparecem mecanismos de negação que impedem o contato com a dor. A solução, neste caso, pode estar vinculada a elaborações melancólicas ou maníacas.

Um paciente do Gr II, na lâmina AG diz: “Não dá para ver nada. Esta está a pior de todas. São quatro pessoas. Esses pioraram mais financeiramente. Estão muito tristes por falta de dinheiro. Eles perderam tudo o que tinham. Vão passar fome, vão morar na rua e vão virar mendigo. Deve ser o futuro deles, coitados, estão perdidos.” A extrema angústia faz emergir a identificação projetiva patológica. $\mathrm{O}$ ego fragilizado submete-se aos objetos internos cruéis. Não existe esperança e predominam a pobreza e a miséria.

Quando a angústia é muito intensa, a impossibilidade de resolver a situação de forma adequada leva o ego a utilizar defesas como a fragmentação e o deslocamento. As histórias apresentam grande desestruturação e incoerência. Um paciente do Gr II diz “(pausa acompanhada de uma expressão de exclamação) Vixe! (pega a prancha olha atentamente e a aproxima do rosto, em seguida a afasta do rosto, parecendo querer ver melhor.) São pessoas com corpo de peixe. Estão olhando umas para as outros.”

De forma geral, nas histórias contadas pelos pacientes do Gr II, na lâmina AG, predominam os mecanismos de negação maníaca ou de escotomização. Neste último, 
temos o seguinte exemplo: "Não é gente não. É banana nanica despencada, uma por cima da outra. Não sei mais nada.” Em outro caso temos a seguinte história: “Esse não dá para ver nada. Esses contornos não me dizem nada. Que coisa esquisita. Parece areia, é acho que é um deserto, sabe quando forma aquelas dunas, é isso mesmo. O vento no deserto." Pode-se citar outro exemplo no qual o paciente diz: "são focas ou cavalos marinhos. Eles estão na praia.”

Nestas histórias observou-se que a situação de perda gerou angústia que o ego não pôde suportar. Fragilizado, nega a realidade interna e externa. A impossibilidade de entrar em contato com a situação leva o ego à distorção da realidade. Distorcendo a realidade, não existe perda e não existindo perda não existe sofrimento. Este é o alívio dado pelas organizações patológicas.

Quanto às elaborações maníacas, temos histórias como esta: "Esta está difícil (pausa) dá impressão de almas. Ah! São seres sobrenaturais que estão entre as nuvens.” O ego não é capaz de manter o equilíbrio, predominando os mecanismos de controle onipotente. Outro paciente frente à lâmina AG apresenta uma resposta típica da utilização dos mecanismos de negação maníaca. Ele diz: “É uma reunião no céu (pausa), estão alegres, festejam alguma coisa. Festejam a confraternização dos homens (pausa), um louvor na igreja. São Anjos em festa.”

A análise das histórias produzidas pelos pacientes diabéticos de mau controle glicêmico, do Gr II, frente à prancha AG, mostra que nas relações estabelecidas predominam os objetos parciais, fragmentados, condensados e de difícil discriminação. A negação maníaca aparece de forma bastante inadequada. Esses pacientes não suportam a perda e evitam de forma sistemática o contato com a realidade. Este tipo de relação objetal é, conforme propõe Simon (2000), característica de pacientes depressivos do tipo esquizo-afetivo ou maníaco-depressivo. “As características da personalidade esquizoafetiva são as de usar a fragmentação do objeto e da própria capacidade de percepção para se livrar de frustração e angústia, dificultando o contato com a realidade externa e 
enfrentar o perseguidor aniquilando-o, com o que cria um círculo vicioso de agressão e perseguição, tornando o perseguidor cada vez mais temível.”(Simon, 2000, p.5).

No caso do paciente diabético de mau controle, observou-se que, geralmente, eles se comportam conforme a descrição de Simon. Eles têm verdadeiro terror da disfunção e não conseguem tomar nenhuma medida para melhorar a situação. Ao contrário, não se tratam, sofrem intensamente pelo medo de morrer e se mantêm paralisados. A cada complicação que leva, inevitavelmente, a uma consulta médica o paciente é obrigado a se defrontar com os estragos causados pelo mau controle. O único recurso após cada um desses episódios é a volta ao refúgio, visto que o paciente não é capaz de lidar com mais uma perda. Intensifica o ódio e o diabetes novamente é negado. Assim, a doença torna-se cada vez mais forte e perigosa e não é mais uma fantasia. De fato existe um perseguidor interno forte e poderoso, e nada se pode fazer contra ele. O distanciamento gera sofrimentos cada vez mais intensos.

As histórias apresentadas pelos pacientes diabéticos do tipo 2 de bom controle glicêmico mostram, na lâmina AG, de forma geral, que eles são capazes de suportar as situações de perda, experimentar o sofrimento e por fim, com a ajuda de bons objetos, manter o equilíbrio interno, elaborando a situação. As histórias apresentam conteúdo humano e de realidade sem distorções. Não existe negação do sofrimento.

Uma das histórias contadas por um paciente diabético de bom controle era a seguinte: “Nossa! O que é isto? Não vejo nada, só uns riscos (pausa). Ah! Parece que é gente! Estão parados, eles têm roupas compridas. Parece que estão numa praia, mas não estão de roupa de banho. Parece uma praia mas não é um passeio. O ambiente está triste dever ter acontecido alguma coisa. Alguma tragédia. Alguém sumiu no mar e eles estão muito preocupados aguardando notícias.” Analisando esta história pode-se perceber que o ego experimenta intensa tristeza frente a situação de perda. No início, ele tende a criar um estado confusional, mas é suficientemente forte para suportar a situação e manter o equilíbrio interno. Fundamentalmente, não se observou a paralisação. A flexibilidade interna permite o desenvolvimento da história e a passagem pelo sofrimento. 
Em outra história o paciente disse: "Estou vendo três pessoas, uma árvore, isso parece ondas feitas pelo vento. Acho que não é árvore. Este é meio difícil. Dá impressão que essas pessoas estão olhando essas ondas que vêm vindo, mas é algo triste que aconteceu. Esta situação dá a impressão de tristeza. É difícil explicar porque o ambiente é triste. É como quando se tem que chorar por coisas que acontecem. Elas estão muito tristes por algo muito ruim que aconteceu.” Novamente observa-se a dificuldade imposta pelo material da lâmina. O conteúdo humano e de realidade provoca sentimentos de perda que evocam grande tristeza e ego temia o contato com esta situação. Fortalecido ele foi capaz de, aos poucos, ir entrando em contato com a situação, sem fragmentar-se ou temer excessivamente o aniquilamento. Com isto foi possível experimentar a tristeza e manter o equilíbrio.

Assim, os pacientes do Gr I de bom controle glicêmico, apesar do grande temor provocado pelo material da prancha, puderam entrar em contato com a situação de perda, suportaram a frustração e, amparados por bons objetos, mantiveram o equilíbrio e chegaram a um desfecho favorável.

\section{C.2 - Análise Comparativa Série B}

Na série $B$, de melhor estruturação se comparada à série $A$, espera-se o aparecimento de defesas de caráter neurótico. As distorções são consideradas mais graves, pois o conteúdo de realidade mais definido gera um número menor de respostas no nível

perceptivo. No nível aperceptivo observa-se a capacidade do sujeito para lidar com a realidade.

Nesta série, apesar de os conteúdos humanos e de realidade serem melhor definidos, os pacientes do Gr II apresentaram predominantemente defesas rígidas e relacionadas à posição esquizoparanóide em suas histórias. 


\section{C.2.1. - Análise da Lâmina B1(6)}

As histórias contadas frente à lâmina B1 retratam a dificuldade dos pacientes para lidar com a situação de solidão. Em um dos casos, a extrema angústia, em virtude do contato com o mundo interno povoado por objetos fragmentados, leva o ego a defenderse através da confusão e depois da paralisação. Um paciente disse: “ metade de um homem entrando em uma sala. (pausa) Esta metade de homem quer entrar em qualquer lugar. (pausa) Ele vai entrar em algum lugar. Ele pode (pausa) não, pode, mas não sei. É só” Ele devolve a prancha ao examinador e fica clara a impossibilidade de ele continuar a história.

Em outro caso, um paciente do mesmo grupo de mau controle glicêmico conta a seguinte história: “Aqui tem um escritório, um homem que está saindo e está dialogando com alguém. São colegas de trabalho e estão conversando. Estão falando do governo ou dos vereadores, das trapaças dos políticos. Ele se sente pior, pois queria distrair e o outro fica falando de coisas ruins. Não sei, mas ficou pior para ele.” Neste caso parece que a situação de solidão faz emergir intensa angústia e o ego não é capaz de suportar. Tenta, através da alucinação positiva, encontrar um objeto bom que lhe dê proteção, mas fracassa pois o objeto, em vez de proteger, transforma-se em mais um perseguidor. Observa-se aqui a repetição da mesma manobra utilizada pelas organizações patológicas apresentadas nas histórias da lâmina A1. Apesar do conteúdo da prancha apresentar na série B melhor estruturação, constata-se a predominância da projeção do mundo interno, independentemente do estímulo externo.

Um último exemplo de uma história contada por uma paciente do Gr II, de mau controle. Frente à lâmina B1 ela diz: “Um quarto, uma cômoda, uma cama, uma pessoa subindo as escadas, vindo em direção ao quarto para dormir. Só. (pausa) Ela está cansada e vai dormir, só. (pausa) Parece uma criança, ela vai entrar no quarto. Mas ela tem medo e não quer entrar no quarto. Ela tem muito medo do escuro, de ficar sozinha e dos fantasmas aparecerem. Ela tem muito pesadelo e não consegue dormir direito. Sou 
eu (começa a chorar), aqui sou eu. Não consigo dormir à noite e fico pensando um monte de coisas ruins.”

Observa-se neste caso que a situação de solidão faz emergir intensa angústia. O ego temia o ataque dos objetos internos ruins, na fantasia representados pelos fantasmas que povoam a noite. No início, observa-se a tentativa de atenuar a angústia através dos mecanismos obsessivos, descrição da prancha. Mas como não funciona só resta ao ego a utilização da identificação projetiva maciça. Perde-se o distanciamento necessário e o paciente não pode mais criar ou sonhar histórias, ganha-se um caráter de realidade. Não é mais uma figura, mas ela mesma. É noite e ela está sendo atacada pelos fantasmas. A paciente demora certo tempo para equilibrar-se, conter o choro e continuar o teste.

Quanto aos pacientes do Gr I , na lâmina B1, as histórias, de forma geral, têm outro curso e desfecho. A situação de solidão é enfrentada mas não existe o sentimento de aniquilamento. Como no caso da seguinte história: “É um quarto no andar de cima, uma pessoa subindo. O quarto tem cama, penteadeira, toalha e um feixe de luz que entra pela porta semi-aberta. Ela vai subir e entrar no quarto, parece noite. Ela está subindo calmamente. Ela vai se deitar, é noite. A pessoa parece tranquila com a mão no bolso, é um homem. Parece também um pouco solitário, triste. Parece ser um quarto muito simples, mas é um ambiente gostoso. Ele sente conforto e gosta de ficar em seu quarto." Neste caso, o paciente não nega a situação de solidão. Recorre aos mecanismos obsessivos que são, neste caso, eficientes. Emerge a tristeza, ligada à posição depressiva, mas o ego é capaz de suportar a situação e, em seu mundo, interno encontrar conforto. Esta parece ser a representação de objetos bons que dão proteção. Neste caso, não existe ação das organizações patológicas.

\section{C.2.2. - Análise da Lâmina B2(9)}

Na lâmina B2, sendo uma situação de par, que geralmente é vista como adulto, pode-se analisar a possibilidade de uma aliança terapêutica através dos vínculos 
estabelecidos. Este dado é importante para o planejamento do tratamento do paciente. Em muitos casos, atendendo pacientes diabéticos, observa-se que eles usufruem bem de grupos de orientação. Em outros casos, porém, as informações parecem não fazer qualquer efeito sobre eles.

Nos pacientes do Gr II, de mau controle, o vínculo estabelecido é permeado pela persecutoriedade. As histórias versam sobre pares atacados e muitas vezes completamente destruídos. Um exemplo é a seguinte história: "uma árvore, debaixo um casal, de frente da árvore tem uma casa. É um casal de namorados. Ela mora nesta casa e como o sol está muito quente vieram debaixo da árvore. Como é domingo, estão de folga e vieram conversar. Será que é marido e mulher? Será que é namorado? (pausa) Se for namorado planeja o futuro. Vão se casar, dar uma festa maravilhosa e vão para a lua de mel em Santos” Esta paciente após contar esta história começa a rir, ri muito e após o riso fica muito séria. Devolve a prancha, dizendo que não tem mais nada para dizer.

Analisando esta situação parece que havia um ataque ao par e, ao mesmo tempo, uma tentativa de evitar o aniquilamento. Mas o predomínio dos impulsos destrutivos não pôde ser contido. Surge a confusão que gradativamente, vai dando lugar à idealização e por fim surge o acting-out.

Este parece ser o meio de ação das organizações patológicas. O ego tenta preservar o objeto e lidar com a situação, mas o medo intenso, experimentado como aniquilamento o leva ao afastamento da realidade, conduzido pela idealização ao refúgio.

Em outro caso, a seguinte história é contada: “ É uma praça com umas árvores, tem uns prédios e é só. (Pausa, devolve a prancha)" No inquérito o paciente acrescenta que: "é uma praça de uma cidade onde as pessoas podem ir para descansar, para esquecer seus problemas, para ficar (pausa), eles vão ficar quietinhos e ficam protegidos do malfeitor que chega e acaba com tudo. Hoje em dia você não pode ficar em lugar nenhum. A violência é muito grande e ninguém tem sossego. Basta você chegar em um lugar para ser assaltado e até outras coisas que nem é bom a gente falar. Só isso." 
Os objetos são sentidos como perigosos e mobiliza extrema angústia que o ego frágil não é capaz de suportar. A identificação projetiva em nível patológico, rigidamente estabelecida, impede o contato com o conteúdo da prancha, com a realidade. Cria-se a fantasia de que a verdade não pode ser encarada, gerando a necessidade de encobri-la a qualquer preço.

Neste grupo, como dissemos anteriormente, encontramos casos em que as histórias tratam de pares que são atacados de forma muito violenta, como neste caso: “Tem uma casa, tem umas janelas e uma porta e aqui uma árvore com duas pessoas ao pé da árvore. Estão à sombra e são colegas batendo papo. Eles são bicha, homem que usa homem como se fosse mulher. Eles têm medo de serem descobertos. Querem ir para outro lugar para ficar mais escondidos. Eles estão abraçados um com o outro. E se forem descobertos vão ser linchados em praça pública.

Nesta história, observa-se que o par interno era sentido como mau continente. Temia ser atacado e o ego experimentava sentimentos de desproteção e abandono. Na impossibilidade de manter o controle frente a esses ataques (= sádicos-anais), o ego cria

objetos extremamente tirânicos através da alucinação positiva. Esses objetos atacam o par, sempre em situação de perigo. Dessa situação, decorre a dificuldade para manter vínculos positivos e saudáveis.

Esta situação de desproteção do par repete-se em várias histórias contadas pelos pacientes do Gr I. São casais abandonados ou desprotegidos. A casa, em vez de ser um bom continente, está desmoronando, está muito velha ou até, como em um caso específico, pegou fogo e nada sobrou. Esses dados são importantes pois demonstram a dificuldade para estabelecer vínculos positivos na relação transferencial. O par não encontra proteção e as fantasias são de que ele está sendo atacado. Na prática, resulta na dificuldade que os profissionais de saúde encontram para lidar com estes pacientes. 
De forma geral os pacientes do Gr I também experimentam sentimentos de ataque ao par, como no Gr II. A diferença é que no Gr I a angústia pode ser suportada e o ego encontra um bom continente para proteger o par. Como no caso desta história: “Eu acho que eles eram felizes quando moravam nesta casa. Estão pensando que eram felizes e de repente tiveram que ir embora. Eles tiveram um caso de doença na família e tiveram que vender as coisas para pagar. Agora eles vão morar num lugar simples e eles sabem que tiveram que fazer isso. Agora depois de resolvido o problema vão lutar e recomeçar tudo de novo" Neste caso, o ego temia os ataques provenientes do mundo externo. Mas a angústia pôde ser suportada, o equilíbrio mantido e, principalmente, foi possível a reparação da situação. São pacientes que possuem esperança, gerada provavelmente pela presença de bons objetos internos.

É importante assinalar que no Gr I encontramos pacientes com capacidade para estabelecer bons vínculos e cujo ego é capaz de encontrar um bom continente, no qual o par é protegido. "É o marido e a mulher que retornam para sua casa. Estão satisfeitos por terem trabalhado e agora voltam para a casa deles.” Nesta história, observa-se que o vínculo é positivo e as situações de par não são temidas. O par adulto, importante para o prognóstico, mostra indícios da possibilidade de boa aliança terapêutica. (Ocampo, 1987)

\section{C.2.3. - Análise da Lâmina B3(4)}

A prancha B3(4) é a primeira desta série a ser apresentada ao paciente. Através desta lâmina, pode-se avaliar o vínculo de “olhar e ser olhado” e "espiar e ser espiado”. Também avalia-se os sentimentos referentes ao fato de ser invadido, controlado ou de incluir-se ou ser excluído do par.

Uma das histórias contadas por um paciente do Gr II mostra que o ego experimenta intensa angústia e não é capaz de suportar a situação de exclusão. A alucinação positiva e a identificação projetiva patológica são mobilizadas e a solução 
encontrada, por causa da agressividade extrema, é o abandono e a morte. "Um casal que está entrando em um quarto, tem uma sombra, não sei se é continuação da outra ( referese à prancha anterior) porque estão consolando a mulher (pausa). Toda a família vai entrar no quarto (pausa). É só." No inquérito ele acrescenta que “A história vai acabar porque a criança morreu e o casal foi aborrecido para casa. A criança tinha uma doença grave e ninguém cuidou dela e ela morreu."

Em outro caso, não existe distorção do conteúdo humano. O paciente vê os três personagens, mas a situação é negada no nível aperceptivo. "São três pessoas, um padre e duas pessoas escutando a pregação. É uma missa comum, nada mais.” No inquérito, o paciente acrescenta que "não existe nenhuma relação entre essas pessoas, só estão na missa, são estranhos.” Para superar a situação, o ego utiliza a negação da realidade. A indiferença impede o contato com os sentimentos envolvidos.

A dificuldade para lidar com a situação triangular e suportar a exclusão é grande neste grupo de pacientes diabéticos de mau controle. Observa-se a agressividade sendo

utilizada de forma destrutiva para evitar o contato com a situação. De forma geral, negase o fato. A análise da ação das organizações patológicas demonstra seu caráter perverso. Se a exclusão é sentida como terrível e gera sofrimento, a organização vem rapidamente em auxílio e aniquila a realidade. Os ataques e a destruição dos objetos ou das relações objetais, como legítima defesa, provocam por um lado o alívio imediato, mas por outro geram a imobilização, representada pela dificuldade para as reintrojeções posteriores. Parece um filme de terror no qual os mortos voltam cada vez mais poderosos.

No Gr I, as histórias contadas frente à prancha B3(4), demonstram que o ego é capaz de enfrentar as situações, apesar do sofrimento. Como nesta história: “O pai com o filho e a mãe mais atrás. Ele está conversando com o filho e a mãe está pensativa e afastada. Ela sabe que é bom ver o filho e o pai conversando, mas ela gostaria de participar da conversa. Mas naquele momento é importante que o pai converse como o filho para ajudá-lo a resolver um problema de trabalho.” A exclusão é suportada, os 
objetos não são atacados e o ego é capaz de manter o equilíbrio, apesar de a situação apresentar certa inadequação pelo fato de a mãe ser a excluída. Neste caso a repressão é utilizada de forma eficiente.

Com relação ao prognóstico, Ocampo (1987) assinala que o mais adequado é a elaboração da situação de exclusão. O paciente deve ser capaz de suportar a presença do terceiro frente ao par unido. "É um casal que está indo dormir. Tem um vulto aqui, parece que é uma criança. É, eles tomaram banho e agora vão dormir. Eles estão bem. Mas a criança fica com medo e quer ir dormir com os pais. Mas ela sabe que não tem jeito, que ela tem que ficar no lugar dela. A mãe percebe e a leva para o quarto. Ela fica meio amuada mas depois dorme bem.” Neste caso, observamos que não existe a negação dos personagens e da situação de exclusão. A capacidade para reconhecer o valor do par unido é outro aspecto a ser considerado no prognóstico.

\section{C.2.4. - Análise da Lâmina BG(10)}

A última prancha da série B é a BG através da qual pode-se avaliar os sentimentos de aceitação, rejeição ou indiferença que o paciente projeta no grupo. Também é possível analisar os sentimentos do paciente em relação à doença e à cura.

No Gr I, as histórias mostram as dificuldades encontradas pelos pacientes para lidar com a situação de exclusão frente ao grupo. Um paciente conta que “ É muita gente não dá para saber. Como eu vou saber o que todo mundo está pensando? Eu não gosto de ficar esperando no ponto. Nunca se sabe o que passa na mente das pessoas. As pessoas pensam coisas ruins. Devem todos estar com muito medo. Não dá para falar sobre essas coisa. É só.” Os objetos são sentidos como perigosos e mobilizam extrema angústia. O ego frágil não é capaz de suportar e a identificação projetiva maciça gera a paralisação. Na transferência observa-se os impulsos destrutivos. 
O estímulo proposto pela Lâmina BG pôde, também, desencadear o ódio em vez de tristeza. A exclusão feita pelo grupo leva o paciente deprimido e protegido pelas organizações patológicas a reagir de forma a aniquilar o objeto. Parece ser este o caso do paciente que conta a seguinte história: "São colegas saindo e um está chegando ao grupo. Ele não vai ser bem recebido porque está tímido. Ele vai ficar bravo, vai buscar vingança e vai exterminar os colegas. Só isso."

Nos pacientes do Gr I, a análise das histórias contadas a partir da Lâmina BG mostra que o ego, de forma geral, teme a situação de exclusão. A angústia que emerge pode ser atenuada através de mecanismos como a repressão e a racionalização. Outro aspecto é o fato de a identificação projetiva ser utilizada de forma adequada, favorecendo o equilíbrio do ego. Como nesta história: "Esta é uma ruína antiga, as pessoas vão visitar. Este é o pai com seus filhos. Este aqui é um desconhecido e aqui são os filhos com o pai. Ele fica admirado de ver o pai com os filhos e aquela harmonia. Gostaria que fosse com ele também porque ele acha bonito. Depois de algum tempo, eles fazem amizade. Ele também aprende com o pai dos meninos."

Em outro caso é interessante observar que a exclusão feita pelo grupo é tratada de forma bastante adequada. O paciente conta que “Tem uma pessoa só que está entrando numa festa e em outra porta tem mais cinco. Estas já estão na festa. Esse outro só está chegando para se encontrar com os outros. Todos participam da mesma festa." Neste caso, o ego defende-se de forma criativa frente à exclusão. A agressividade é mantida em nível adequado e a idealização aparece de forma equilibrada. O desfecho é favorável.

\section{C.3 - Análise Comparativa Série C}

A novidade desta série é a inclusão da cor, que aumenta o clima de tensão e mobiliza os sentimentos agressivos entre o indivíduo e o grupo. “O controle adaptativo é esperado em termos de diagnóstico e prognóstico, bem como o uso de defesas que 
empobrecem o ego, tais como a negação, o triunfo e o controle onipotente.”(Rosa, 1995, p.15)

\section{C.3.1. - Análise da Lâmina C1(12)}

A prancha C1(12) mostra como o paciente experimenta a situação de teste com o examinador e quais os sentimentos que ele vivenciou na transferência. O que ele pensa e sente em relação à despedida e os recursos que ele tem para o começo de um tratamento.

As histórias produzidas pelos paciente diabéticos de mau controle frente à prancha C1, são permeadas pela persecutoriedade. As defesas utilizadas, de modo geral, são rígidas e não permitem a elaboração da situação, não apenas de empobrecimento do ego, como é esperado nesta série, mas de confusão e paralisação como meios de defesa. Uma das histórias é: “Bom aqui parece uma cozinha. Tem cadeiras, mesa, xícara e bule. Mas está tudo vazio. Não sei o que aconteceu aqui. Não dá para saber, eu não sei não. Está muito difícil não sei não.” Frente à situação de solidão e de abandono, o ego recorre ao controle obsessivo. Como fracassa, instala-se a confusão e o ego fica paralisado.

Em outro caso o ego não é capaz de suportar a persecutoriedade da situação. A extrema angústia gera o ódio contra o examinador. A identificação projetiva maciça impede a criatividade e o paciente não consegue separar a fantasia da realidade. Experimenta sentimentos de ser atacado. Como não pode discriminar, atua. "Mas que confusão! Eu não sei para que fazer isto. Acho que é só para confundir a gente. É isso mesmo (pausa). Tem uma cadeira, uma jarra, parece xícara, uma cortina, um pano com coisas vermelhas. Aqui eu vou te dizer, não acontece nada. Não tem nenhuma pessoa. Muito difícil (pausa). Vejo uma sombra atrás da cortina. A cortina estava meio aberta. A sombra, não tem pessoa, mas para que fazer isso com a gente? Ela deve estar puxando a cortina, eu não sei não. Parece que é de propósito para pegar a gente. Eu não sei mais o que é isto. Se era para fazer pegadinha já fez. Só.” 
Na história mostrada no parágrafo acima, de um paciente de mau controle, pôdese observar que o ego tenta manter o controle da situação através dos mecanismos obsessivos, mas fracassa. Na lâmina C1, os pacientes diabéticos do Gr I, utilizam estes mesmos mecanismos obsessivos para atenuar a angústia. Na maioria dos casos, o ego é capaz de controlar a situação, suportar a despedida, resultando no seu equilíbrio. Como nesta história: “(vira a prancha e olho o verso) É uma casa(pausa), é uma cozinha, tem uma mesa, cadeira, vitrô, tem cadeiras, coisas em cima da mesa. Tem uma pessoa no vitrô. Ela está arrumando a casa, a família tomou café e ela está cuidando de organizar a cozinha. Ela gosta de arrumar, mas também fica cansada. Depois que ela arrumar tudo vai descansar."

\section{C.3.2. - Análise da Lâmina C2(11)}

A lâmina C2 (11) estimula as fantasias de perda. O ego frente, a esta situação, é solicitado a mobilizar recursos para reparar o objeto destruído. No presente estudo, esta prancha tem valor especial considerando que o diabético vive a perda do corpo saudável. Espera-se que a maneira de lidar com o material desta prancha sirva como indício de como o paciente resolveu sua situação real a partir do diagnóstico do diabetes.

Os pacientes do Gr II, de mau controle, com exceção de um caso, não suportaram o contato com a situação de perda. Com a distorção da realidade, não havendo perda, o ego é poupado e o sofrimento, evitado. A identificação projetiva maciça, a alucinação negativa, a idealização e a paralisação são as principais defesas utilizadas. Nestes casos pode-se observar a ação das organizações patológicas.

Uma paciente frente à lâmina C2 disse: "É a entrada do Centro, aqui tem uma mulher e uma televisão. Ela está muito feliz. É um lugar maravilhoso onde todo mundo é bem atendido e sai curado. As pessoas são muito boas e tudo dá certo.” Devolve a prancha dizendo que não tem mais nada para dizer. Neste caso, a idealização extrema está a serviço do encobrimento à verdade. O Centro de Diabetes é um lugar onde as 
pessoas com diabetes, doença incurável, vão para se tratar. Através da identificação projetiva maciça a paciente se vê em situação de tratamento. Na impossibilidade de lidar com tal situação, a realidade é transformada pelas organizações patológicas e ela obtém a cura.

Outra história traz o seguinte conteúdo: “Mas só tem coisa ruim nessas figuras? Nossa! Aqui é um homem que vai entrar no quarto para matar o outro homem. Ele vai morrer e acabou a história. Fim.” A violência dos ataques não deixa a menor possibilidade de reparação. O ego parece em perigo iminente, experimenta intensa angústia e, para não ser destruído, ataca o objeto e o aniquila.

Quando a angústia atinge níveis muito altos, o ego recorre a defesas extremas. Existe grande confusão e a realidade confunde-se com a fantasia. Uma paciente disse: " $E$ uma pessoa. Parece uma sala ou uma casa porque aqui tem uma porta. Homem o que você faz? (a paciente pergunta ao quadro e sorri) ele me falou que vai em algum lugar. O homem talvez more talvez não. Acho que não. É um setor do trabalho dele, onde ele trabalha. Deve ser o trabalho. É só.” O ego não suporta o contato com o objeto atacado, distorce a realidade através da alucinação negativa e recorre ao acting-out. Não consegue manter o equilíbrio e fica paralisado.

Os pacientes do Gr I, de bom controle, de forma geral conseguem enfrentar o sofrimento mobilizado frente à lâmina C2. Através das histórias, observa-se que o objeto atacado pode ser visto e, principalmente, cuidado. Os mecanismos reparatórios são mobilizados e o ego mantém o equilíbrio. As histórias retratam pessoas que vêm cuidar do outro, ajudar. Em muitos casos, são pessoas que estão doentes e o outro vem trazer remédios ou apenas ver estão melhor. Em todos os casos a reparação é estabelecida e a relação é permeada pelos impulsos libidinais.

Um exemplo é a seguinte história: "Este parece que está chegando no quarto e vai visitar uma pessoa. Parece um homem que vai visitar um doente. Parece que está triste o ambiente. Parece uma casa pobre. A pessoa que está doente é solitária e está recebendo a visita de um amigo. Eles ficam satisfeitos um por poder ajudar e o outro por 
receber ajuda." Neste caso observa-se que o ego foi capaz de entrar em contato com a situação e com a tristeza. A possibilidade de suportar a situação reparando o objeto permitiu a elaboração da situação.

\section{C.3.3. - Análise da Lâmina C3(3)}

Nesta prancha são mobilizados os sentimentos relacionados ao conflito edipiano. Todos os pacientes do Gr II, frente a esta prancha, construíram histórias pobres, nas quais prevaleceram as relações de objeto muito negativas. A intensa ansiedade mobilizada não permitiu que o equilíbrio fosse mantido. As defesas predominantes eram identificação projetiva patológica, alucinação negativa e idealização. Por exemplo: “Aqui tem uma pessoa em pé e um sentado. É uma mulher. A senhora vai rir, doutora, mas é uma pessoa pedindo oração. É a mulher de costas que pede oração para o que está de pé em frente ao santo. Ele está doente, jogado, desanimado. A mulher está em desespero, por isso queria uma oração. Ela estava muito angustiada e não foi buscar ajuda com os homens,, mas sim com Deus. Sabe, doutora, ela era uma pessoa de fé e Deus vai curar. Só. Não precisa mais dizer nada. Acabou." O refúgio oferecido por Deus impede o contato com a situação e o sofrimento termina.

Em outro caso, o paciente disse: “É um desenho (pausa). É um homem com uma criança e ele está examinando a criança. Tem um sofá, tem uma pessoa deitada, encostada. Tem mais um homem de pé em frente a uma espécie de altar. A pessoa do sofá é um homem. Mas é só um desenho, não é de verdade, é só um desenho. Não sei mais dizer nada. É só um desenho.” As identificações projetivas maciças parecem provocar muita angústia que o ego não pode suportar. Como recurso ocorre a paralisação.

Frente à lâmina C3, os pacientes de bom controle glicêmico constróem histórias nas quais prevalecem as relações de objeto com tendência adaptativa, mas com resultante negativa. Existe certa dificuldade para lidarem com o material mobilizado pela prancha. Um exemplo é a seguinte história: “Isto eu não sei o que é (aponta para a esfera 
vermelha, pausa). Eu estou vendo dois homens e uma mulher. Parece que estavam tomando café. Este levantou-se para ver não sei o que? Devia ser noite porque tem o abajur. Mas eu não sei, parece o sol entrando. Isto aqui não dá para saber o que é (esfera vermelha). Eles estão em uma sala. Ele levantou assustado e apressado para pegar um objeto ou alguma coisa. Não são parentes não. Acho que são. Acho que é uma família. É o pai e dois filhos. O pai repreendeu ele porque chegou atrasado. A irmã também ficou surpresa com a reação do pai.” A situação triangular fazia emergir impulsos agressivos. A intensa ansiedade não podia ser suportada, levando o ego a um estado confusional. O ego tende ao equilíbrio apesar da persecutoriedade do objeto.

Em outro caso a situação triangular mobiliza intensa angústia. O clima é de tristeza e doença. O ego fragilizado não sucumbe em função da presença de bons objetos capazes de reparar a situação. "Tem uma pessoa caída, está doente na cama, em uma casa. A outra está conversando. Uma está de pé e quer pegar a maçã para dar para o doente. Está dando conselhos para o outro, o doente vai receber a maçã. Tem um abajur. Tem um quarto. Eles estão tristes, muito tristes. A mulher que está conversando procura ajudar o doente. Só.”

\section{C.3.4. - Análise da Lâmina CG(7)}

Nesta prancha é apresentada uma situação de grupo. A distribuição espacial das figuras apresentada na lâmina CG(7) e a presença de cores permitem explorar a maneira como o paciente encara as figuras de autoridade, tanto no nível interno como no externo. No grupo de pacientes com mau controle glicêmico, as histórias demonstram a dissociação interna. As defesas apresentadas são: identificação projetiva patológica, fragmentação e paralisação.

Um paciente deste grupo conta a seguinte história: “Uma gangue surrou um rapaz, deixaram ele caído no chão e saíram todos correndo. O rapaz ficou muito ruim, mas logo foi socorrido pelos populares.” No inquérito, ao ser perguntado sobre o que 
havia acontecido com o moço, o paciente responde: "Eu não conheço nenhuma dessas pessoas. Acho que eles pensam, a gangue, que o rapaz que apanhou tinha mexido com a irmã de um deles. Terminou ele machucado e os outros sumiram. Não sei o que vai acontecer, não dá para saber." O ego parece invadido pelos impulsos destrutivos provenientes dos objetos internos vingativos. A extrema crueldade desses objetos gera angústia, que o ego tenta, sem sucesso, atenuar através de objetos bons. Com o predomínio dos impulsos destrutivos o ego fica paralisado.

Predomina neste grupo, frente ao material mobilizado pela lâmina CG, o mecanismo de paralisação. Este material apresenta a força dos impulsos destrutivos e o predomínio das organizações patológicas impedindo qualquer possibilidade de mudança. Como na seguinte história, apresentada por outro paciente do Gr II: “Oh! Meu Deus (pausa) Seria uma escada? Tem plantas aqui embaixo e no lado de cima uma pessoa caída. É só. Não sei o que aconteceu a pessoa foi subindo e caiu. Chega, não quero mais falar."

O conteúdo humano de forma geral foi negado. Em vez de pessoas, os pacientes retratam pedras, matas, florestas, canteiros, madeiras e lagos. As histórias são descritas “coisificando” todos os personagens como no seguinte caso: “É uma floresta, tem um banco, tem canteiros. Essa é difícil imaginar alguma coisa. Acho que não está acontecendo nada. Ah! O banco está esperando por alguém que vai chegar e fazer fofocas.” Em outro caso, a extrema angústia leva a mecanismos maníacos pouco adequados à realidade: “Finalmente uma que não está muito ruim. Está em um lugar bonito. Acho que sua situação está mais de acordo. Parece que é um jardim. Este é um jardim e ele está muito feliz em seu maravilhoso jardim."

No grupo I, frente à prancha CG, os pacientes constróem histórias que demonstram a permeabilidade do mundo interno. De uma forma geral, as defesas são eficientes e o equilíbrio interno é mantido, resultando no estabelecimento de relações de objeto positivas. Uma das histórias era a seguinte: “Aqui é um grupo de pessoas e eles foram reivindicar seus direitos. Esta é a prefeitura e o prefeito veio receber as pessoas. 
Eles subiram a escada e pediram para o prefeito não fechar a escola que eles estudavam. Foi o diretor, os professores e alguns alunos. Eles não queriam que fechassem a escola porque eles não poderiam mais estudar e eles não queriam parar de estudar. Eles conversaram com o prefeito e depois de muita conversa o prefeito disse que não ia mais fechar a escola. Todos festejaram e foram para suas casas felizes. No começo, o prefeito ficou preocupado e pensou que eles queriam confusão, mas depois ele viu que eles tinham razão e ficou satisfeito com a sua decisão."

A análise desta história demonstra que havia permeabilidade entre id/ego/superego. Os impulsos destrutivos provenientes do id puderam ser utilizados de forma adequada e foram contidos pela força do ego, que manteve o equilíbrio interno, apesar de certa idealização. O fato de o paciente não negar o conteúdo humano é de bom prognóstico. Além disso, o fato de as figuras humanas não apresentarem aspectos de idealização ou de perseguição extremas demonstra também o equilíbrio interno.

Em outra história, pôde-se observar o mesmo fenômeno. O paciente conta que: "Vejo umas árvores bonitas, campos. Um lugar que parece que vai chover. Na parte de baixo tem pessoas, gente que vem chegando e andam neste lugar limpo. É uma pousada, eles vieram passear e depois vão embora. Eu não tinha visto! Tem alguém do lado de cima. Ele vai ficar olhando, ele cuida de tudo no lugar, de verificar se vai sair tudo bem. Ele tem que cuidar do lugar, verificar se está tudo bem. Ele é o dono da pousada.” Havia permeabilidade entre as instâncias psíquicas e o equilíbrio era mantido.

Esta análise comparativa entre as produções realizadas pelos pacientes diabéticos do tipo 2, de bom e de mau controle, mostra que eles apresentam funcionamento psíquico muito diferente. Nos pacientes diabéticos de bom controle observou-se a presença de bons objetos internos e a capacidade para suportar a frustração e estabelecer bons vínculos além da possibilidade de lidar com a realidade da maneira como ela é apresentada. As distorções no nível perceptivo são pequenas e as apercepções são compatíveis com o material mobilizado pela prancha. Na realidade, parece que isto implica na possibilidade de o paciente lidar com o fato de ser diabético de forma realista, 
de aceitar o tratamento e de manter uma atitude positiva em relação à sua situação de portador de uma disfunção crônica.

Por outro lado, a análise das histórias dos pacientes diabéticos do tipo 2, de mau controle, revela uma situação completamente diferente. As distorções no nível perceptivo são marcantes e determinam imediatamente a impossibilidade de o paciente lidar com o material apresentado. A angústia predominante é persecutória e o paciente, geralmente, não é capaz de lidar com a realidade apresentada. Observou-se que o mundo interno está povoado por objetos persecutórios. A capacidade para suportar o sofrimento e a frustração é mínima assim como a capacidade para estabelecer bons vínculos. Em decorrência disto, surge a ação das organizações patológicas, como meio de aliviar o paciente do sofrimento insuportável.

\section{V - CONCLUSÃO}

Considerando os objetivos deste trabalho, foram analisados 30 pacientes diabéticos do tipo 2, divididos em dois grupos, compostos cada um por 15 pacientes. $\mathrm{O}$ Gr I tinha pacientes de bom controle glicêmico e o Gr II , pacientes de mau controle glicêmico.

O objetivo principal deste trabalho era analisar se havia influência das organizações patológicas nos pacientes com mau controle glicêmico, determinando a não aderência destes pacientes ao tratamento. Sabemos que o bom controle glicêmico depende fundamentalmente de fatores como dieta, exercícios físicos e medicação. Ou seja de um bom tratamento. Como observamos que muitos pacientes não aderem ao tratamento, interessava-nos investigar os fatores envolvidos nesta atitude.

Para realizar esta investigação optamos pela utilização de dois instrumentos. O primeiro foi a Escala Diagnóstica Adaptativa Operacionalizada (EDAO) e o segundo o Teste das Relações Objetais (TRO). Através destes instrumentos, os dados foram coletadas e analisados. 
Através da EDAO pôde-se constatar que os pacientes do Gr I, de bom controle glicêmico, apresentam, predominantemente, respostas adequadas. Nestes pacientes a presença de fatores negativos geravam crises, como esperado, mas eram superadas, elaboradas. As perdas geravam sofrimento, mas a pessoa suportava a realidade e, após certo período, era capaz de fazer novos vínculos, caracterizados pela confiança e o amor. A libido, anteriormente investida no objeto perdido, era destinada a um outro objeto, com o qual era estabelecido novo vínculo. Estes pacientes não estavam paralisados e foram capazes de buscar soluções que mantinham o nível de adequação. O impacto do diagnóstico, apesar de gerar crise, pôde ser assimilado de forma adequada. De forma geral estes pacientes não sofreram prejuízos irreparáveis.

Os pacientes do Gr II, de mau controle glicêmico, deram respostas pouco adequadas, mais predominantemente do tipo pouquíssimo adequadas. Este tipo de resposta soluciona o problema do indivíduo mas, em contrapartida, gera conflitos internos ou externos, ou não traz nenhuma gratificação.

Na realidade, por não serem capazes de dar soluções adequadas aos seus problemas, esses pacientes criam um ciclo no qual o sofrimento, apesar de aniquilado pelas organizações patológicas, presentes através da onipotência, da arrogância e idealização, é cada vez mais intenso. Estes mecanismos defensivos agem de tal forma que a realidade é distorcida e todo o sofrimento supostamente é evitado. Diz-se supostamente porque o paciente, em seu refúgio, não se dá conta de que, na realidade, ele sofre um grande engano. No caso do paciente diabético, além de continuar diabético, a falta de contato com esta situação gera uma série de complicações que gradativamente, prejudicam sua adaptação de forma significativa e, muitas vezes, irreversível.

Simon (2000) descrevendo pacientes depressivos mostra que as soluções pouco ou pouquíssimo adequadas quando aliadas a objetos internos persecutórios ou idealizados formam as organizações patológicas, descritas por Steiner (1987). 
A análise através da EDAO mostrou que de fato os pacientes diabéticos de mau controle encaixam-se de forma precisa neste modelo. São pacientes que não aceitam a sua disfunção. Eles consideram os profissionais de saúde como objetos ruins e destrutivos. A medicação e todo o tratamento é encarada também como destrutiva. Como não conseguem discriminar objetos bons de ruins, de forma geral, nesta situação tudo se mistura e nada pode ser considerado como benéfico. Qualquer tentativa de acesso a estes pacientes parece em vão.

Através do TRO pode-se confirmar os dados obtidos através da EDAO. O grupo de bom controle demonstrou nas respostas dadas às lâminas do TRO que o mundo interno destes pacientes, de forma geral, apresenta-se bastante equilibrado. Nas situações de angústia, o paciente mostra que é capaz de passar da posição esquizoparanóide à posição depressiva. Frente à angústia persecutória, o ego recorre e recebe ajuda dos objetos bons. Estes, firmemente estabelecidos, geram confiança e fortalecem o ego, que é capaz de superar as situações. Não se observa o predomínio dos impulsos destrutivos. As situações, conforme apresentadas pelas pranchas do TRO, puderam ser encaradas, o sofrimento pode ser vivenciado e as situações de crise e dificuldade, superadas. Principalmente neste grupo, observou-se a capacidade para suportar a frustração.

No grupo de pacientes com mau controle glicêmico, um dos problemas refere-se às dificuldades com a identificação projetiva. A utilização desta defesa é feita pelos pacientes do Gr I de forma adequada. Enquanto eles são capazes de manter uma distância saudável, produzindo histórias ricas, com conteúdo adequado para a proposta da prancha, nas histórias dos pacientes do Gr II observa-se a falta de esperança. Elas são pobres e os personagens se atacam pois não encontram proteção e estão identificados com aspectos superégoicos cruéis e punitivos, próprio de personalidade depressiva, conforme descreve Grassano (1996). Além disso, as histórias são repetitivas e apresentam sempre os mesmos personagens. Em alguns casos, o paciente chegou a dizer que se tratava da mesma pessoa em todas as pranchas. O conteúdo também é repetitivo, envolvendo doença e morte. A identificação projetiva utilizada de forma maciça gera a pobreza interna. A rigidez está 
presente e nada pode ser criado. Este é o resultado da ação do sistema defensivo patológico.

Estes pacientes diabéticos do grupo de mau controle, geralmente, negam a situação de terem diabetes. Observou-se que, nas situações de solidão impostas pelas lâminas com um personagem, predominou a angústia persecutória. Nos casos em que o paciente cria, através da alucinação positiva um segundo personagem, este, em vez de ajudar, apresenta características de crueldade e persecutoriedade. Eles se vêem obrigados a continuar na solidão, pois o objeto alucinado em vez de libertar, aprisiona. Nas lâminas de par a situação se repete. O par é sentido como ruim e não encontra continente apropriado. Também nas situações triangulares e nas de grupo, observou-se o mesmo fenômeno. O outro ou os outros estão sempre em atitude de ataque e portanto precisam ser eliminados ou idealizados.

Este resultado explica na prática a dificuldade que a equipe de saúde encontra para trabalhar com estes pacientes. Nestas situações, os pacientes experimentaram sentimentos de ataque e destruição. O outro não vem para ajudar, mas para atacar, como no caso do médico, por exemplo, quando ele diz que o paciente está diabético e que ele precisa se tratar. Na visão do paciente, obscurecida pela ação das organizações patológicas, o médico não entende nada, não sabe nada e o que diz não é verdade. Procuram outros médicos e inconscientemente fazem dieta e comprovam que não são diabéticos. Estes pacientes são levados para um lugar, um refúgio, onde a dor não precisa ser experimentada. São levados ao "paraíso" como forma de impedir o contato com a realidade de ser diabético. Esta falta de contato com a realidade e o encobrimento da verdade, impedem que medidas preventivas sejam tomadas. Na sua visão está tudo sob controle, não existe dor, mas também não existe vida. Está tudo morto, aprisionado.

Como o profissional de saúde é encarado desta maneira, como um objeto que ataca, o paciente geralmente não retorna à consulta. Na fantasia do paciente, significa que tanto o diabetes como o profissional não existem mais. Tanto que é comum o paciente procurar atendimento em situação de crise, com uma complicação importante, e dizer que 
não é diabético. Algumas vezes, eles afirmam que já foram, mas que estavam curados, situação na qual observamos a ação das organizações patológicas. Elas oferecem uma segurança perversa, leva o paciente a acreditar que a realidade não precisa ser enfrentada. Neste sentido, parecem estabelecer um conluio com o ego que está fragilizado.

De maneira diferente, os pacientes do Gr I, de bom controle, aceitam as orientações e a dependência. Eles acreditam que os profissionais de saúde podem ajudar. As relações estabelecidas são permeadas pela esperança e os bons objetos estabelecidos no mundo interno os ajudam a suportar a frustração pela perda do corpo saudável.

Grassano(1996) ao descrever o clima emocional das histórias de pacientes depressivos (e parece ser este o caso dos pacientes diabéticos do tipo 2, com mau controle glicêmico), diz que os personagens são inibidos emocionalmente e que não são capazes de utilizar sua agressividade para lutar e modificar sua própria situação. Prevalece a submissão em virtude da fantasia de que se lutarem estarão fadados à morte. Em alguns casos mais graves, como de uma depressão crônica, observa-se uma indiferença total, não existe oponente, portanto não existe motivo para lutar. De tempos em tempos, por ocasião de uma complicação, o paciente diabético sai de seu refúgio. Mas a impossibilidade de enfrentar a situação o leva novamente ao esconderijo.

A conclusão deste trabalho aponta para o fato de que a configuração das organizações patológicas, conforme foram descritas e propostas por Steiner (1997), apresentam grande semelhança com o modelo observado em pacientes diabéticos do tipo 2, com mau controle glicêmico.

Finalmente, quero ressaltar dois aspectos o primeiro é que o diabetes do tipo 2 é uma síndrome que se instala de forma suave, e que por esse motivo é apontada por muitos como “uma doença silenciosa”. Muitos pacientes só percebem que são diabéticos por causa de uma complicação grave. Isto quer dizer que os altos níveis de açúcar no sangue, imperceptíveis a olho nu, agem silenciosamente, comprometendo a saúde da pessoa. De forma muito semelhante a ação das organizações patológicas ocorre, também, de forma silenciosa e quase imperceptível, comprometendo a saúde psíquica. Este é um aspecto que dificulta o tratamento. 
O segundo aspecto diz respeito ao tratamento destes pacientes diabéticos, que apresentam como defesa este sistema tão poderoso. Cabe aos profissionais de saúde fazer um acompanhamento, em equipe. Esta é uma tentativa de compreender as dificuldades destes pacientes e buscar maneiras de não reproduzir o modelo que eles apresentam, fator fundamental para a não aderência ao tratamento. Geralmente o que ocorre é que o profissional, mobilizado pela contratransferência, concretamente torna-se um perseguidor e ataca, contribuindo para o fracasso do tratamento. Além disso, conforme mostra Noronha (2000), o problema destes pacientes, seduzidos pelas organizações patológicas, referem-se as dificuldades para viver e não para morrer. 


\section{V - Referências Bibliográficas}

Aikens, J.E. \& Mayes, R. (1997). Elevated glycosylated albumin in NIDDM is a function of recent everday environmental stress. Departament of Psychiatry. University of Chicago. Diabetes Care, Jul, 20 (7), 1111-3.

Alleyne, S.I. (1987). Social indicators, illness behaviour and mortality among patients with diabetes mellitus in Jamaica, West Indies. Kingston, S.N.; 317p. University of the West Indies, Mona para obtenção do grau de Ph.D.

Anderson, B.J. (1991). Interactionist theory of patient compliance: A model and exploration. The Fielding Institute. DAI-B 51/09, Marc, p.4589.

Baranger, W. (1994). Validade do conceito de objeto da obra de Melanie Klein. In W. Baranger (Org), Contribuições ao Conceito de Objeto em Psicanálise (G.G. de Almeida, trad.) (pp. 39-55). São Paulo, SP: Casa do Psicólogo.(Original publicado em 1977)

Bion, W. R.(1988) Diferenciação entre a personalidade psicótica e a personalidade não psicótica In Estudos Psicanalíticos Revisados (W.M.M. Dantas, trad.). ( pp. 45 62) Rio de Janeiro, RJ: Imago.(Original publicado em 1957)

Bion, W.R. (1963) Elementos da Psicanálise. (J. Salomão \& P. D. Corrêa, trad.) Rio de Janeiro, RJ: Imago.

Bleger, J. (1984) Psico-Higiene e Psicologia Institucional. Porto Alegre, R.G. do Sul: Artes Médicas. (Original publicado em 1962 e 1965)

Bleger, J.(1985) Simbiose e Ambigüidade: Estudo Psicanalítico. (M.L.X. de A . Borges, trad.) Rio de Janeiro, RJ: Francisco Alves Ed.(Original Publicado em 1967) 
Booty, K. ( 1992) The relationship of coping resources and knowledge to glicemic control among diabetic patient. Pepperdine University.

Chacra, A.R., Dib, S.A., Ferreira, S.R.G., Franco, L.J. \& Col.(1999) Diagnóstico e Classificação do Diabetes Mellitus e Tratamento do Diabetes Mellitus Tipo 2 Recomendações da SBD - Sociedade Brasileira de Diabetes.

Clayer, J.R. , Bookless-Pratz, C. \& Harris, R.L.(1985) Some health consequences of a natural disaster. Medical Journal. Aust - Sep.2 143(5), pp. 182-4.

Cleaver, G.\& Pallourios, H. (1994)Diabetes mellitus: Experiencing a chronic illness. South - African Journal of Psychology. Vol. 24 (4), Dec.

Costa-Rosa, A . (1995) Práticas de Cura nas Religiões e Tratamento Psíquico em Saúde Coletiva. Tese de Doutoramento. São Paulo: SP, Universidade de São Paulo.

Costa, S.F. (1998). Introdução Ilustrada à Estatística. São Paulo, SP: Harbra

Cummings, N.A (1992) Psychologists: An essential component to cost-effective, innovative care. American College of Healthcare Executives Meeting. JN Psychotherapy in Private Pratice. Vol. 10(1-2), pp. 137-143

Davidovich, N.R. (coord) (1989) Orientações Básicas para o Diabético. Brasília, Ministério da Saúde.

Davies, R. (1989) Psychological care, counselling and diabetes - Parte 2. Medical Perspective Diabetic. Sep-Oct, 6(7), pp.643-4.

Dib, S.A. (1984) As Proteínas Glicosiladas no Diabetes Mellitus: Metodologia e Significado Clínico. Tese de Doutoramento. São Paulo: SP, Universidade Federal de São Paulo. 
Docherty, M. (1988) Glycaemic control, regimen compliance and causal atributions in diabetic people .Pract Diabetes. 5(6), 274-6.

Dunn, S.M., Smart, H.H., Beeney, L.J.\& Turtle, J.R.(1986) Measuremt of emotional adjustment in diabetic patients: Validity and Realiability of ATT 39. Diabetes Care. Sep-Oct 9(5), pp. 480-9.

Ebigo, P. O. \& Oli, J.M. (1985) Stress in the life of nigerian diabetics. Psychosom Medical Psychoanal. 31(3), pp. 267-83.

Freud, S. (1973) Obras completas. Editorial Biblioteca Nueva, Madrid, Espana, 3 a edição, Tomo II. ( Original publicado em 1917).

Franco, L.J. (coord) (1989) Estudo multicêntrico da prevalência do diabetes mellitus no Brasil. Ministério da Saúde, CNPQ, FAPESP, OPASM, SEMS.

Gandini, R.C. (1995) Análise estatística e interpretação semântica do questionário adaptativo operacionalizado. Revista Mudanças. Ano III - no. 3/4, pp. 83-107.

Godoy, M.B.R. (1994) Narciso e a morte precoce de édipo: uma organização mental patológica a serviço desta tragédia. Tese de Doutoramento. São Paulo, SP: Universidade de São Paulo.

Goodrich, S. W. (1994) Social support and dietary adherence of elderly persons with non - insulin - dependent diabetes mellitus. University of South Florida. DAÍ - B . 55/05, pp. 1791, nov.

Grassano, E. (1996) Indicadores Psicopatológicos nas Técnicas Projetivas.(L. S. L. P. C. Tardivo, trad.). São Paulo, SP.: Casa do Psicólogo. 
Guimarães, M.M. (1987) Alguns aspectos no acompanhamento do diabetes mellitus infanto juvenil. Revista do IMIP - Instituto Materno Infantil de Pernambuco. Vol. 1, no. 2, Julho/ Dez , pp. 185-188.

Haynal, A .\&; Pasini, W.(1983) Medicina psicossomática. ( L. Meyer, trad.). São Paulo, SP: Editora Masson.

Heleno, M.G.V.(1992) Estudo da eficácia adaptativa e do controle glicêmico em pacientes diabéticos do tipo 2. Tese de Mestrado. São Bernardo do Campo, SP: Instituto Metodista de Ensino Superior.

Jornal Informativo do Conselho Federal de Psicologia (1998). Psicologia é indispensável no atendimento em oncologia. Ano XIII n ${ }^{\circ}$ 56, Dez., p.8.

Jensen, S.B. (1985) Emotional aspects in diabetes mellitus: A study of somatopsychological reactions in 51 couples in which one partner has insulintreated diabetes. Journal of Psychosomatic Research. Vol. 29(4), pag. 353-9.

Joseph, B. (1975) O paciente de difícil acesso in Michael Feldman e Elizabeth Bott Spillius (Org.), Equilíbrio Psíquico e Mudança Psíquica. (B. H. Mandelbaum, trad.) (pp. 85 - 96) Rio de Janeiro, RJ: Imago.

Kaplan, R.M. (1987) Effects of Diet and Exercise Interventions on Control and Quality of Life in Non-insulin-dependent Diabetes Mellitus. J Gen Intern Med. Jul-Aug, 2(4) p. 220-8.

Klein, M. (1981) Contribuições à psicanálise. ( M. Maillet, trad.). São Paulo, SP: Mestre Jou. (Original publicado em 1940) 
Klein, M. (1986). Notas sobre alguns mecanismos esquizóides. In J. Riviere (Org), Os Progressos da Psicanálise (A . Cabral, trad.) ( pp. 313 - 343 ). Rio de janeiro, RJ: Editora Guanabara, $3^{\mathrm{a}}$. edição. (Original publicado em 1946).

Klein, M. (1986) Algumas conclusões teóricas sobre a vida emocional do bebê. In J. Riviere (Org), Os progressos da Psicanálise. ( A . Cabral, trad.) ( pp. 216 - 255) Rio de Janeiro, RJ. Editora Guanabara. (Original publicado em 1952).

Krall, L.P. (1983) Manual do diabete de Joslin. (R. S. Azevedo Neto, trad.) São Paulo, SP: Livraria Rocca.

Kreger, C. (1992) The psychological impact of diabetes mellitus: a comparative study. Dissertation Degree MED. University of Alberta - Canadá.

Leite, E.C.C. (1989) Relações objetais no Delírio Hipocondríaco: um estudo com o teste de Phillipson. Tese de Mestrado. São Bernardo do Campo, SP: Universidade Metodista.

Lima, M.G. (coord) (1991) Avaliação do psicodrama aplicado a educação do diabético juvenil. Arquivo Brasileiro de Endocrinologia.

Lima, M.G., Goldfeder, A .J., Franco, L.J., Nery, M. Tambascia, M. A ., Pacheco, A ., Veti, M.F., Foss, M.C., Raffaelli, R.Jr., Madeira, S.A ., Dib, S.A .\& Colab. (1990) Manual de fundamentos técnicos sobre diabetes mellitus e tratamento. Grupo de trabalho de diabetes do GEPRO de doenças Crônicas Degenerativas do SUDS. São Paulo, SP.

Lúcio, M.G.D. (coord). (1990). Avaliação do grau de conhecimento sobre a doença em diabéticos internados e a sua correlação com cursos de orientação. Arquivos Brasileiros de Endocrinologia. 
Ma, J.T. \& Robinson, J. D. (1988) Hyperglycemia is a stress response in a acute stroke. Department of Medicine. University of Hong Kong. Stroke. 19(11): 1359-64, Nov.

Negrato, C.A., Salgado, M.H., Oda, R.M., Oda, G.M., Kato, R.N., Zampieri, A. L., Rocha, O. S. \& Oliveira, A.A. (1999) Diabetes e Medicina Alternativa. Associação de Diabéticos de Bauru. Aracaju, Sergipe: XII Congresso Brasileiro de Diabetes.

Meltzer, D. (1991) Terror, Perseguição, Pavor - Uma dissecção das ansiedades paranóides In E. B. Spillius (Org), Melanie Klein Hoje - Desenvolvimentos da teoria e da técnica - Volume 1. (B. H. Mandelbaun, trad.) ( pp. 234 - 242). Rio de Janeiro, RJ: Imago.

Mutti, R.K.\& Lima, M.G. (1990) Correlação entre características de personalidade e controle metabólico em crianças e jovens com diabetes tipo 1. São Paulo, SP: Hospital do Servidor Público Municipal.

Nasri, F., Sá, J.R., Milito, L., Ramos, L.R. \& Dib, S.A .(1998) Impacto do Valor da Glicemia de Jejum no Diagnóstico de Diabetes Mellitus em Indivíduos Idosos. Disciplina de Endocrinologia - UNIFESP - EPM. Águas de Lindóia, SP: Congresso de Diabetes e Metabologia.

Ocampo, M.L.S., Arzeno, M. E. G. \& Grassano (1987). O Processo Psicodiagnóstico e as Técnicas Projetivas.(M. Felzenszwalb, trad.). São Paulo, SP: Editora Martins Fontes, $5^{\mathrm{a}}$. edição.

O’Shaughnessy, E. (1991) Um estudo clínico de uma organização defensiva. In E. B. Spillius (Org), Melanie Klein Hoje Desenvolvimento da teoria e da técnica Volume 1. (B. H. Mandelbaun, trad.) ( pp. 297 - 315). Rio de Janeiro, RJ: Imago. (Original publicado em 1979) 
Phillipson, H. (1981) Test de relaciones objetales. Argentina, Buenos Aires: Paidos.

Rey, J.H. (1991) Fenômenos esquizóides no paciente fronteiriço - Borderline. In E. B. Spillius (Org), Melanie Klein Hoje Desenvolvimento da teoria e da técnica Volume 1. (B. H. Mandelbaun, trad.) ( pp. 208 - 233). Rio de Janeiro, RJ: Imago. (Original publicado em 1979)

Rosa, J.T. (1988) Pensamento clínico no diagnóstico Psicológico: Relações objetais de dois pacientes depressivos. São Paulo, SP: Simpósio - A criança. Casa do Psicólogo.

Rosa,J.T. (Org.) (1995) Atualizações clínicas com o teste de relações objetais de Phillipson. Associação de Psicoterapia e Estudos Psicanalíticos. Santo André, SP: Lemos.

Rosenfeld, H. (1988) Impasse e interpretação. (P. M. Rosa, trad.). Rio de Janeiro, RJ: Imago.

Rosenfeld, H. (1991) Uma abordagem clínica para a teoria psicanalítica das pulsões de vida e de morte: uma investigação dos aspectos agressivos do narcisismo. In E. B. Spillius (Org), Melanie Klein Hoje Desenvolvimento da teoria e da técnica Volume 1. (B. H. Mandelbaun, trad.) ( pp. 243 - 259). Rio de Janeiro, RJ: Imago. (Original publicado em 1971)

Ross, M., Ribeiro, J.S., Oliveira, J.E.P.\& Cordeiro, J.G.H. (1987) Diabetes mellitus - tipo 2 - Revisão e Atualização. Instituto de Endocrinologia Santa Casa de Misericórdia do Rio de janeiro: CM. Nov-Dez,. Vol.5, num. 10.

Rossini, S.R.G. (1985) Estudo das relações objetais de dois casos de depressão para indicação de Psicoterapia Breve. Estudos de Psicologia. Campinas, SP: PUCCAMP, vol.2, 2 e 3, pp.122-134. 
Samo, J.A . (1991) Effects of psychological stress on blood glucose in diabetes mellitus. University of Florida. DAI - B . 52/04, p. 2346.

Silva, J.C.V.V.B. (1989) Variabilidade Adaptativa num grupo de pacientes e suas evoluções em psicoterapia individual de orientação psicanalítica. Tese de Mestrado. São Bernardo do Campo, SP: Instituto Metodista de Ensino Superior.

Simon, R. (1984) Contribuições ao estudo do objeto interno. Revista Brasileira de Psicanálise, 18(3), pp. 283-300.

Simon, R (1986) Introdução à Psicanálise: Melanie Klein. São Paulo, SP: Editora Pedagógica e Universitária.

Simon, R. (1989) Psicologia clínica preventiva. São Paulo, SP: Editora Pedagógica e Universitária.

Simon, R. (1998) Luto não elaborado e relações de tempo, lugar e memória. Boletim de Psicologia. Vol. XLVIII, $\mathrm{n}^{\circ}$ 108: 49-66o.

Simon, R. (1998) Proposta de Redefinição da EDAO - Escala Diagnóstica Adaptativa Operacionalizada. Mudanças, Ano VI, nº 10, 13-24.

Simon, R. (2000) Variedades de Depressão e a Teoria da Adaptação Considerações Psicoterápicas. Trabalho apresentado na Divisão de Psicologia do Hospital das Clínicas da Faculdade de Medicina da USP, Centro de Convenções Rebouças, São .Paulo, em 24.03.2000.

Sohn, L. (1991) Organização narcísica, identificação projetiva e a formação do identificado. In E. B. Spillius (Org), Melanie Klein Hoje Desenvolvimento da teoria e da técnica - Volume 1. (B. H. Mandelbaun, trad.) ( pp. 275 - 296). Rio de Janeiro, RJ: Imago. (Original publicado em 1985) 
Soiffer, R. (1992) Psiquiatria Infantil Operativa. (J. C. A . Abreu \& F. F. Settineri).RS: Artes Médicas, $3^{\mathrm{a}}$. edição.

Steiner, J. (1997) Refúgios Psíquicos - Organizações Patológicas em Pacientes Psicóticos, Neuróticos e Fronteiriços. São Paulo, SP: Imago.

Tatterson, R.B. et al. (1985) Group therapy in the treatment of diabetes. American Diabetes Association. Diabetes Care. Vol. 8, nº 2, mar-apr. 180.8

Torquato, M.T.C.G., Viana, L.A .L., Montenegro, Jr., R.M, Souza, R.A .H.G., Lanna, C.M.M., Lucas, J.C.B., Bidurin, C. \& Foss, M.C. (1998) Comparação dos níveis Glicêmicos de Jejum de 2 h após sobrecarga com glicose para Diagnóstico de Diabetes Mellitus - Dados Preliminares do Estudo de Prevalência de Diabetes Mellitus no Município de Ribeirão Preto. Secretaria Municipal de Saúde de Ribeirão Preto - Programa de Diabetes e Hipertensão; Divisão Endocrinologia e Metabologia; Departamento de Clínica Médica e Liga de Diabetes do Centro Acadêmico Rocha Lima; Faculdade Medicina de Ribeirão Preto - Universidade de São Paulo. Águas de Lindóia, SP: III Congresso Paulista de Diabetes e Metabolismo.

UK Prospective Diabetes Study Group. Tight blood pressure control and risk of macrovascular and microvascular complications in type 2 diabetes: UKPDS 38, BMJ 317: 703-12, 1998.

Vazquez Estupinan, F., Arreola, F., Castro Martinez, G., Escobedo de la Pena, J., Fiorelli, S., Gutierrez, C., Junco Lorenzana, E., Islas, S., Lifshitz, A ., Mendez, J.D., Partida Hernandez, G., Revilla, C.\& Salazar Schettino, B. (1994). Aspectos psicosociales de la diabetes mellitus. Ver. Med. IMSS. , mayo - jun 32 (3) : 26770. 
Viard.R., Harter,M., Couadau, A ., Sayegh, M.I., Albrengues, P., Fenichel, P., Irondelle, G.; Strulo, S.\& Kozlowski, J.M.(1984) Le diabete et sa dimension psychique. Jornées de Diabetologie. Paris, pag. 10-29.

Yoshida, E. M. P. (1989). Estudo de Critérios Psicodiagnósticos para Indicação de Psicoterapia Breve. Tese de Doutoramento. São Paulo, SP: Universidade de São Paulo 